\title{
Juvenile Salmonid Pit-Tag Studies at Prosser Dam and the Chandler Canal Fish Collection Facility, Yakima River, 1991 and 1992
}

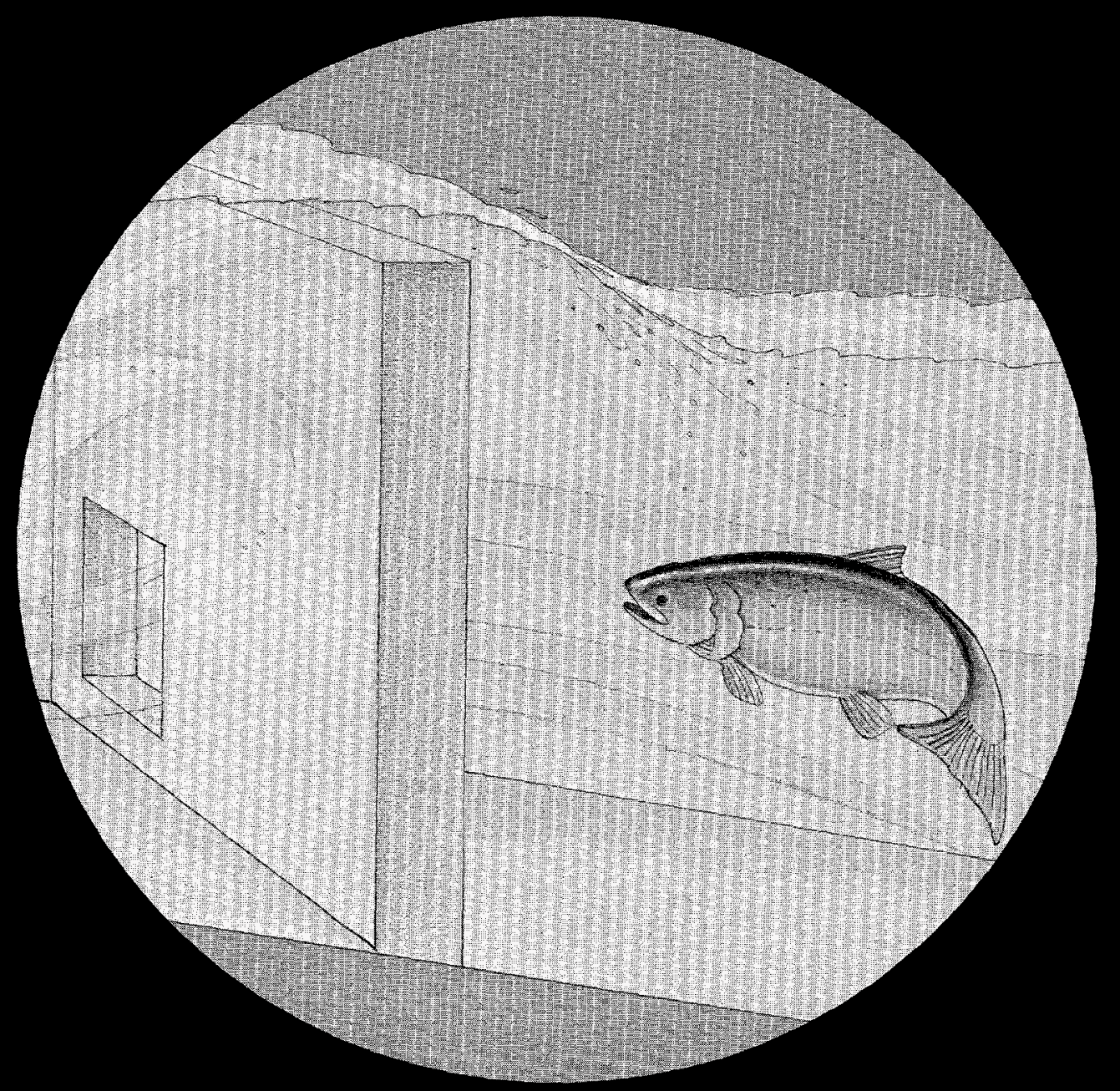

Final

Report

U.S. Department of Energy

Bonneville Power Administration Division of Fish \& Wifdlife

Coastal Zone and Estuarine

Studies Division

Northwest Fisheries Science Center

National Marine Fisheries Service

National Oceanic and

Atmospheric Administration 
This report was funded by the Bonneville rower Administration (BPA), U.S. Department of Energy, as part of BPA's program to protect, mitigate, and enhance fish and wildlife affected by the development and operation of hydroelectric facilities on the Columbia River and its tributaries. The views in this report are the author's and do not necessarily represent the views of BPA.

For additional copies of this report, write to:

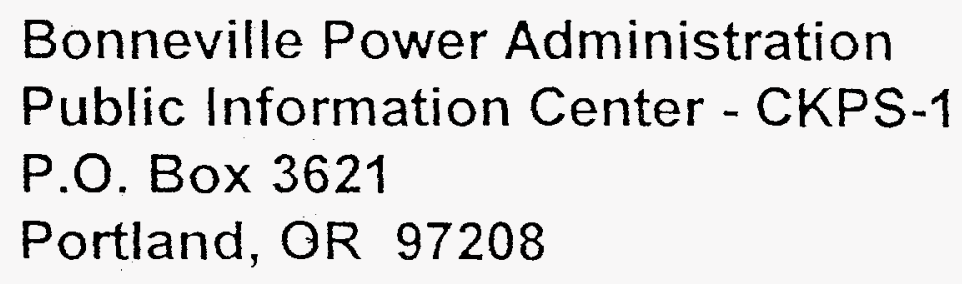

Please include title, author, and DOE/BP number from the back cover in the request. 


\section{DISCLAIMER}

This report was prepared as an account of work sponsored by an agency of the United States Government. Neither the United States Government nor any agency thereof, nor any of their employees, makes any warranty, express or implied, or assumes any legal liability or responsibility for the accuracy, completeness, or usefulness of any information, apparatus, product, or process disclosed, or represents that its use would not infringe privately owned rights. Reference herein to any specific commercial product, process, or service by trade name, trademark, manufacturer, or otherwise does not necessarily constitute or imply its endorsement, recommendation, or favoring by the United States Government or any agency thereof. The views and opinions of authors expressed herein do not necessarily state or reflect those of the United States Government or any agency thereof. 



\title{
JUVENILE SALMONID PIT-TAG STUDIES AT PROSSER DAM AND THE CHANDLER CANAL FISH COLLECTION FACILITY, YAKIMA RIVER, 1991 AND 1992
}

\section{FINAL REPORT}

\author{
Prepared by: \\ Benjamin P. Sandford \\ and \\ Thomas E. Ruehle
}

\begin{abstract}
Funded by:
Coastal Zone and Estuarine Studies Division

Northwest Fisheries Science Center

National Marine Fisheries Service

National Oceanic and Atmospheric Administration

Seattle, Washington

and
\end{abstract}

U.S. Department of Energy

Bonneville Power Administration

Environment, Fish and Wildlife

P.O. Box 3621

Portland, OR 97283-3621

Project Number 90-065

Contract Number DE-AI79-90BP07099.

January 1996 

EXECUTIVE SUMMARY $\ldots \ldots \ldots \ldots \ldots c_{1}^{\text {Page }}$

INTRODUCTION . . . . . . . . . . . . . . . 4

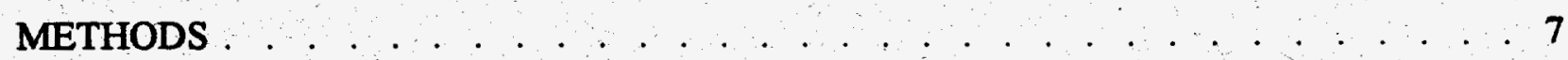

Experimental Design _. . . . . . . . . . . . . . 7

Data Analysis $\ldots \ldots \ldots \ldots$

Database Procedures $\ldots \ldots \ldots \ldots$

Quality Control . . . . . . . . . . . . . 9

Multinomial Likelihood Estimation $\ldots \ldots$

Expanded Detection Proportion Estimation $\ldots \ldots \ldots$

Relative Recapture Estimation $\ldots \ldots \ldots \ldots$

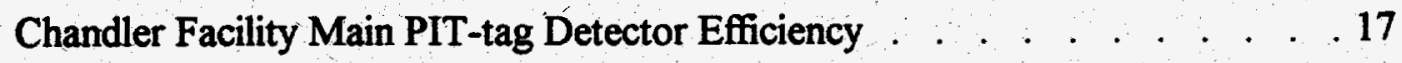

Survival Relationship with Water Temperature and Flow . . . . . . . $\quad .17$

Chandler Canal Flow Diversion versus Fish Entrainment $\ldots \ldots \ldots$

Travel Time $\ldots \ldots \ldots \ldots \ldots \ldots \ldots \ldots \ldots \ldots$

RESULTS AND DISCUSSION $\ldots \ldots \ldots$

Test Conditions $\ldots \ldots \ldots \ldots$

Quality Control . . . . . . . . . . . . . . . 19

Tests of Assumptions $\ldots \ldots \ldots$

Assumption Al $\ldots \ldots \ldots \ldots$

Assumption A2 $\ldots \ldots \ldots \ldots$ 
CONTENTS--Continued.

Survival . . . . . . . . . . . . . . . . . . .

Estimates . . . . . . . . . . . . . 33

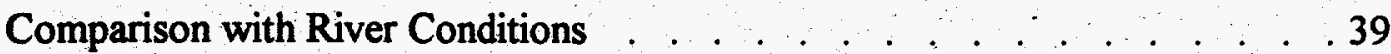

Chandler Canal Water Flow versus Fish Entrainment . . . . . . . . . . . .43

Maximum Likelihood vs Expanded Detection Proportion and Relative Recapture . . 51

Chandler Facility Main PIT-tag Detector Efficiency . . . . . . . . . . . . 51

Travel Time . . . . . . . . . . . . . . . . . . . . . 53

Chandler Facility $\ldots \ldots \ldots$

McNary Dam . . . . . . . . . . . . . . . . . . . . . . 58

SUMMARY . . . . . . . . . . . . . . . . . . . 62

RECOMMENDATIONS . . . . . . . . . . . . . . . . . . . . . .

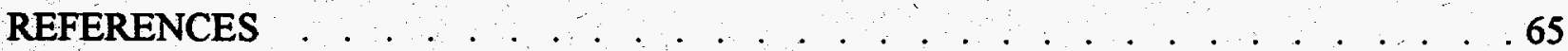

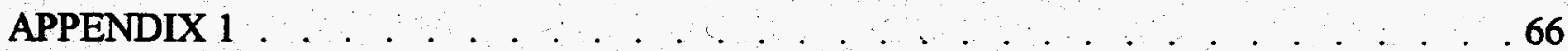

APPENDIX $2 \ldots \ldots \ldots \ldots$

APPENDIX TABLES $\ldots \ldots \ldots \ldots$ 


\section{EXECUTIVE SUMMARY}

In 1991 and 1992, the National Marine Fisheries Service completed the second and third years of a 3-year study to estimate juvenile salmonid (Oncorhynchus spp.) timing and survival characteristics related to passage through the Prosser Dam complex, including the Chandler Canal and the Chandler fish collection facility, on the Yakima River. Yearling chinook (O. tshawytscha) and coho salmon ( $O$. kisutch) were collected at the Chandler facility, PIT tagged, and released at various locations in the Yakima River, Chandler Canal, and the Chandler facility. Individual fish were subsequently detected at PIT-tag detection monitors at the Chandler facility and/or McNary Dam on the Columbia River. Survival through various reaches, PIT-tag detection efficiency, and Chandler Canal fish entrainment proportion parameters were estimated using maximum likelihood techniques.

The research objectives in 1991 and 1992 were to: 1) assess the effects of passage through the Chandler Canal and the Chandler facility on the survival of juvenile salmonids, 2) determine the entrainment rate of juvenile salmonids into the Chandler Canal as a function of river flow, and 3) determine the efficiency and reliability of the PIT-tag monitoring system at the Chandler facility. The initial 1990 research plan was expanded in 1991 and 1992 to include several more release locations and many more release days.

A total of 26,267 yearling chinook and 8,359 coho salmon in groups of approximately 200 fish in 1991 and 125 fish in 1992 were PIT tagged and released at each release location. Releases were made over 35 days in 1991 and 11 days in 1992. Mortality related to the tagging and holding process for both years was approximately $1 \%$. Data from three of the release dates were 
not used in the analyses due to apparent malfunctions of the main PIT-tag detector in the Chandler facility.

In general, the assumptions of the statistical methodology were not violated. However, data from one of the release days was not used in the maximum likelihood analysis due to violation of one of the assumptions.

The measured mortality in the Chandler Canal and facility was $7-16 \%$ for yearling chinook and $11 \%$ for coho salmon. This mortality increased to $63 \%$ after mid-May 1992 , when canal water temperatures exceeded $15^{\circ} \mathrm{C}\left(59^{\circ} \mathrm{F}\right)$ and water flow was less than $30.0 \mathrm{cms}(1060 \mathrm{cfs})$.

Prediction curves relating the proportions of water $(\mathrm{Fl})$ and fish $(\mathrm{Fi})$ entrained into the Chandler Canal were calculated as $\mathrm{Fi}=1.368-0.234 / \mathrm{Fl}$ and $\mathrm{Fi}=0.828+0.213 \times \mathrm{Fl}$ for yearling chinook and coho salmon, respectively. Entrainment estimates into the Chandler Canal under various flows based on these curves will have fairly low precision, will be valid only for flows observed in these studies, and will require adjustment for expected Chandler Canal survival:

Fish entrainment proportion and survival estimates for Chandler Canal were also generated using information from Chandler facility detections of fish released in the Prosser Dam forebay and at the headworks of the Chandler Canal. These estimates were quite similar to the statistically optimum maximum likelihood estimates and the methods used to calculate them can be used for future studies. However, $100 \%$ survival in the Prosser Dam forebay must be assumed and the Chandler facility PIT-tag detection efficiency must be estimated.

The detection efficiency of the Chandler facility main PIT-tag detector was estimated as consistently exceeding $95 \%$, although at least three down-time occasions lasting several hours were observed. 
Most of the PIT-tagged fish released above the Chandler facility were detected within a few hours. Median travel time to McNary Dam decreased over time, from as long as 17 days to as short as 6 days for yearling chinook salmon and from 5 days to 3 days for coho salmon.

If precise survival estimates in the Yakima River system are required, additional studies are needed to improve precision and accuracy of the estimated fish/flow entrainment relationship and determine more accurately mortalities related to passage through the Chandler Canal and facility. Also, high efficiency of the Chandler facility PIT-tag detection system should be maintained and detector malfunctions or down-time should be fully documented. 



\section{INTRODUCTION}

Juvenile salmonid survival studies planned for the Yakima Basin will require the release and recapture of large numbers of marked fish. Before these studies can be implemented, information is needed about potential recovery and survival rates of marked fish at proposed sampling sites. The type of mark employed and the efficiency of equipment used to detect or capture and examine fish must be evaluated, since accurate and precise survival estimates depend on their reliability. Recovery and survival rates are expected to vary with species and life stage as well as environmental factors such as river flow and water temperature.

The Chandler Canal originates downstream from Prosser Dam at river kilometer 76 on the Yakima River (Figs. 1 and 2). This canal delivers water for power production (approximately $28.3 \mathrm{~m}^{3} / \mathrm{second}(1000 \mathrm{cfs})$ ) and irrigation (approximately $11.3 \mathrm{~m}^{3} / \mathrm{second}$ ( $\left.400 \mathrm{cfs}\right)$ ). A trash removal and fish diversion screen facility is located $1.6 \mathrm{~km}$ downstream from the canal headworks. A bypass pipe diverts fish through the Chandler Canal juvenile fish collection facility (Chandler facility) and back into the Yakima River (Fig. 2).

In 1990, the National Marine Fisheries Service (NMFS) began a 3-year study to assess the mark-recovery capabilities of the Chandler facility and to estimate juvenile salmonid timing and survival characteristics related to passage through the Chandler Canal and facility. Results of the 1990 study were reported by Ruehle and McCutcheon (1994). The primary objectives of the 1991 and 1992 studies were:

1) To assess the effects of the Chandler Canal and the Chandler facility passage on the survival of juvenile salmonids; 


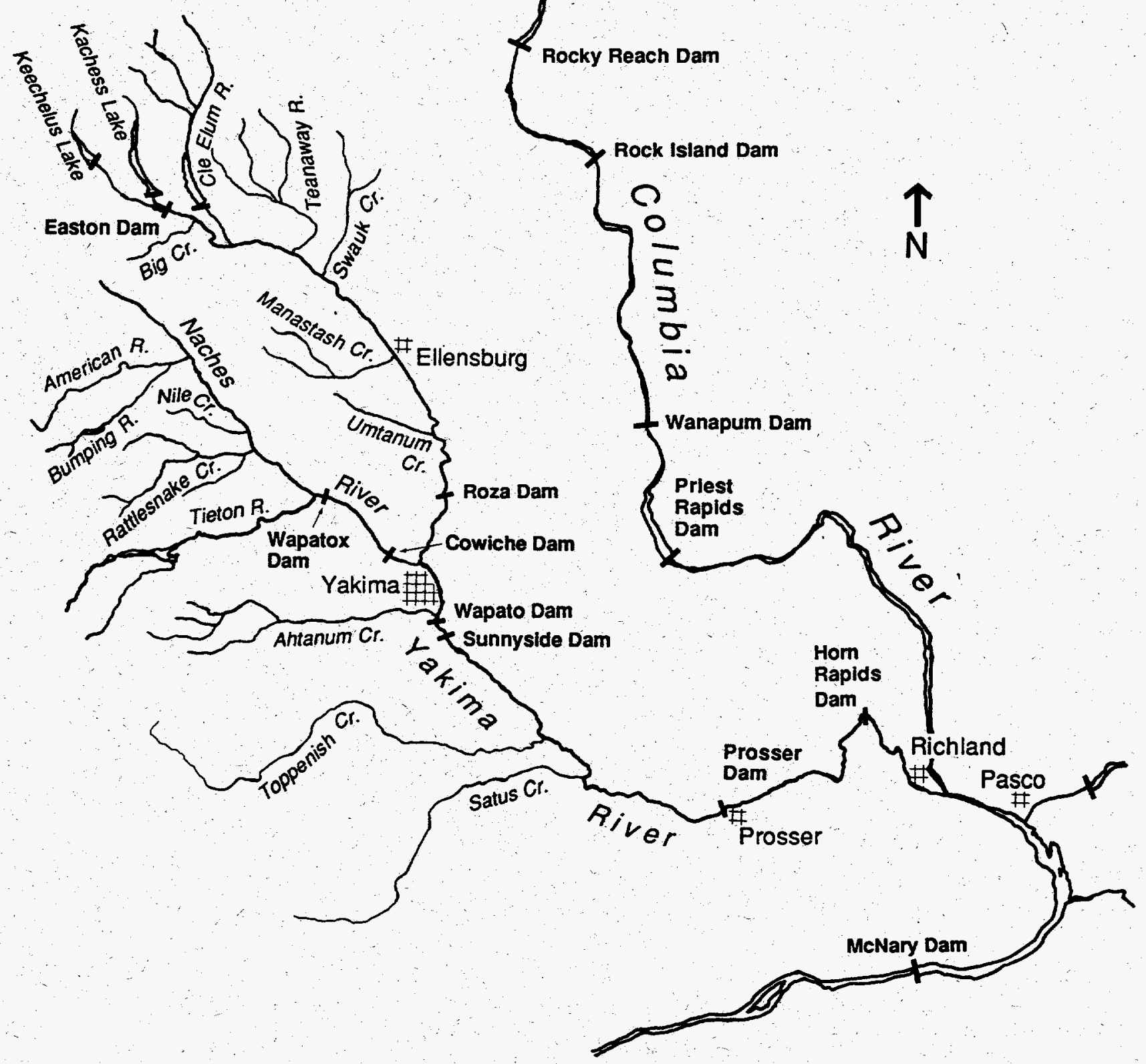

Figure 1. Map of the Yakima River and the adjacent Columbia River showing locations of major water diversion and hydroelectric dams. 


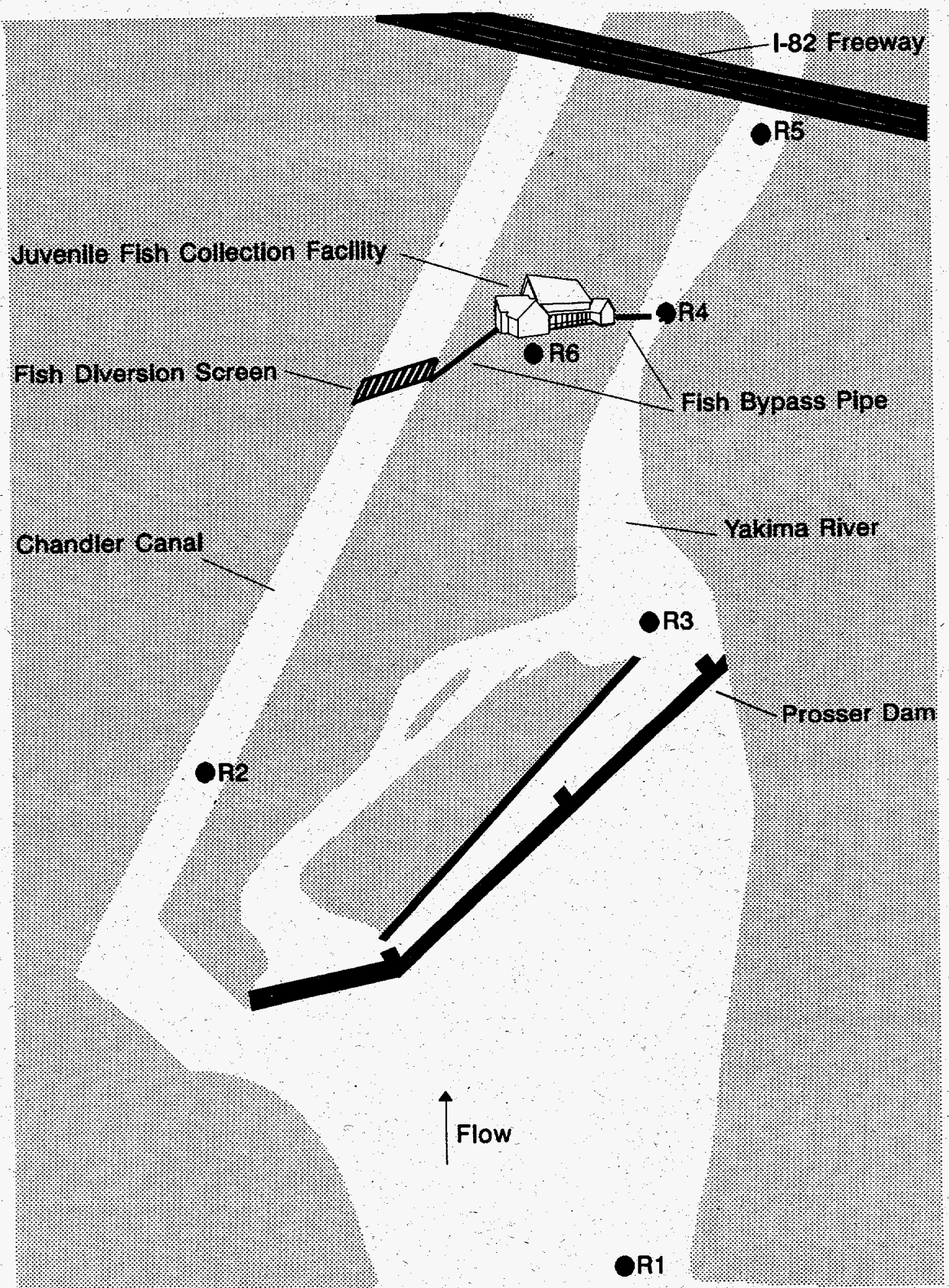

Figure 2. Yakima River near Prosser, WA showing Chandler Canal, juvenile fish collection facility, and release locations (OR) of PIT-tagged juvenile salmon. 
2) To determine the entrainment rate of juvenile salmonids into the Chandler Canal as a function of river flow; and

3) To determine the efficiency and reliability of the PIT-tag monitoring system at the Chandler facility;

\section{METHODS}

\section{Experimental Design}

Yearling chinook salmon (Oncorhynchus tshawytscha) and coho salmon (O. kisutch) were acquired from the sampling system in the Chandler facility. The fish were PIT tagged using procedures and equipment similar to those described by Prentice et al. (1990). Fish were rejected prior to tagging if they were diseased, injured, descaled, or previously marked. After tagging, fish were allowed to recover in portable containers supplied with aerated water from the Chandler Canal. Individual release groups were held in separate containers. PIT-tagged fish were held for a minimum of 24 hours for recovery and to evaluate delayed mortality. Equal numbers of fish were tagged for all releases on the same day, with generally 200 and 125 fish per release location in 1991 and 1992, respectively.

PIT-tagged fish were released in the evening as simultaneously as possible at all release locations. The release locations were as follows (see Fig. 2):

R1 = Approximately one km upstream from Prosser Dam.

R2 = The headworks of the Chandler Canal.

R3 = Immediately below Prosser Dam. 
R4 = At the Chandler facility outfall.

R5 $=$ At the I- 82 bridge.

R6 = Immediately after the main PIT-tag detector in the Chandler facility.

PIT-tagged fish were subsequently detected at the main and sample PIT-tag detectors at the Chandler facility (R1 and R2) and/or the main and sample detectors at McNary Dam (all releases). Tagged fish included in the sample at the Chandler facility were held until the following morning, examined, and released into the outfall pipe.

\section{Data Analysis}

\section{Database Procedures}

Completed tag and release files were electronically transferred (uploaded) to the PIT-tag Information System (PTAGIS) database maintained by the Pacific States Marine Fisheries Commission (PSMFC). Uploaded files contained tagging session and release details (dates, locations, etc.) and information for each tagged fish (PIT-tag code, species, length, miscellaneous comments, etc.). PIT-tag detections were collected automatically by the PIT-tag detectors at the Chandler facility and McNary Dam, and information such as PIT-tag code and observation date and site for each detected fish was uploaded to an observation file.

The initial data analysis step was to retrieve data from the PTAGIS tagging and observation files. For each year, tagging and observation reports were generated in the commaseparated variable (CSV) format and contained the combined information from all releases. The tagging report contained one record of tagging and release information per PIT-tagged fish, while the observation report contained multiple records per PIT-tagged fish: one for every detection time and location. 


\section{Quality Control}

The reports described above were examined for erroneous records, inconsistencies, and data anomalies. Records were eliminated or information corrected where appropriate. A record of all eliminations or changes was kept. Records were eliminated for the following reasons:

1) PIT-tagged fish was detected before release.

2) Detected PIT-tagged fish was previously classified as a mortality.

3) PIT-tagged fish was detected at McNary Dam before detection at the Chandler facility.

4) PIT-tagged fish was detected at the Chandler facility from release groups R3-R6.

Mortalities that occurred between tagging and release were recorded, and a mortality file was uploaded to PTAGIS. A CSV mortality report was generated, and subsequently mortalities were eliminated from the tagging report.

Due to the quality control process, all data used in statistical analyses were from PITtagged fish known to be released alive at the intended release location and date and whose detection records were consistent and logical as to downstream passage.

\section{Multinomial Likelihood Estimation}

The following parameters were estimated using maximum likelihood estimation procedures (Burnham et al. 1987, Mood et al. 1974):

$\mathrm{S} 1=$ Survival probability from one $\mathrm{km}$ above Prosser Dam to its tailrace or the beginning of Chandler Canal.

S2 = Survival probability from the beginning of Chandler Canal to the main PIT-tag detector in the Chandler facility. 
S3 = Survival probability from the Prosser Dam tailrace to the Chandler facility outfall.

$\mathrm{SA}=$ Survival probability from just below the sample diversion gate in the Chandler facility to the outfall.

S4 = Survival probability from the Chandler facility outfall to the I-82 bridge (estimated only in 1992).

SMI = Combined probability of survival from the Chandler facility outfall to, and recapture at, McNary Dam (estimated in 1991).

SM2 = Combined probability of survival from the I-82 bridge to, and recapture at, McNary Dam (estimated in 1992).

D = Diversion probability into Chandler Canal.

P = Detection probability in the Chandler facility (i.e., detection by the main or sample PIT-tag detectors).

The data were summarized in detection histories ${ }^{1}$ as defined in Table 1 . The detection histories were assumed multinomially distributed for each release group. The likelihood function was the probability of the observed data viewed as a function of the parameters (Burnham et al. 1987). Therefore, a multinomial likelihood function was used for each release group and the likelihood model for the study was written as a product of I independent likelihoods, where I was the number of release groups ( $I=4$ for 1991 and 5 or 6 for 1992).

${ }^{1}$ Detection histories were denoted as capture histories in the historical mark-recapture literature. However, PIT-tagged fish were not "captured" as much as their passage through a location was "detected". 
Table 1. Potential detection histories for PIT-tagged yearling chinook and coho salmon released in 1991 or 1992. Abbreviations: CHF-Chandler facility; MCN-McNary Dam; R1approximately one $\mathrm{km}$ upstream from Prosser Dam; R2-the headworks of the Chandler Canal; R3-immediately below Prosser Dam, R4-the CHF outfall; R5-the I-82 bridge; R6-immediately below the main PIT-tag detector in the CHF.

\begin{tabular}{|c|c|}
\hline $\begin{array}{l}\text { Detection } \\
\text { History }\end{array}$ & Explanation \\
\hline 111 & Released at R1, detected at the CHF, detected at MCN. \\
\hline 110 & Released at R1, detected at the CHF, not detected at MCN. \\
\hline 10.1 & Released at R1, not detected at the CHF, detected at MCN. \\
\hline 100 & Released at $\mathrm{Rl}$, not detected at the $\mathrm{CHF}$, not detected at $\mathrm{MCN}$. \\
\hline 211 & Released at $\mathrm{R} 2$, detected at the $\mathrm{CHF}$, detected at $\mathrm{MCN}$. \\
\hline 210 & Released at R2, detected at the CHF, not detected at MCN. \\
\hline 201 & Released at $\mathrm{R} 2$, not detected at the $\mathrm{CHF}$, detected at $\mathrm{MCN}$. \\
\hline 200 & Released at R2, not detected at the CHF, not detected at MCN. \\
\hline 31 & Released at R3, detected at $\mathrm{MCN}$. \\
\hline 30 & Released at R3, not detected at MCN. \\
\hline 41 & Released at $\mathrm{R} 4$, detected at $\mathrm{MCN}$. \\
\hline 40 & Released at R4, not detected at $\mathrm{MCN}$. \\
\hline 51 & Released at R5, detected at $\mathrm{MCN}$. \\
\hline 50 & Released at R5, not detected at MCN. \\
\hline 61 & Released at R6, detected at MCN. \\
\hline 60 & Released at R6, not detected at MCN. \\
\hline
\end{tabular}


The goal of the estimation procedure was to find the parameter values that maximized the likelihood function; that is, the values which gave the greatest likelihood of giving rise to the observed data (Kendall and Stuart 1977, Hogg and Craig 1978). This was done for the likelihood function in this study using an iterative Newton-Raphson procedure (Seber 1982). The procedure required reasonable initial estimates, which were obtained using method-of-moment (MOM) estimators derived as shown in Appendix 1 (Mood et al 1974). Maximum likelihood estimates (MLEs) were the parameter solutions of the iterative procedure. The last step in the iterative procedure also provided estimates of the asymptotic standard errors of the MLEs based on the assumed multinomial sampling variability (Seber 1982).

Several different likelihood models were used to obtain MLEs for the various situations in this study. Separate models were used for 1991 and 1992 study years, and one or two additional releases ( $R 5$ or $R 5$ and $R 6$ ) were made in 1992: this allowed estimation of the parameters S4 and SM2 rather than just SM1 as in 1991. Also, in cases where the best initial MOM estimate for $P$ and/or D was $100 \%$ (i.e., 1.0), P and/or D were fixed at $100 \%$ in the likelihood models (due to mathematical constraints), and the remaining parameters were estimated.

Maximum likelihood estimation was preferred over method-of-moment estimation. MLEs are theoretically statistically superior to MOMs because they have asymptotic properties including normality, unbiasedness, and minimum variance (Kendall and Stuart 1977).

Tests of assumptions--For the multinomial likelihood analyses, there were two critical assumptions: 
A1) All PIT-tagged fish in a release group had homogeneous and independent survival probabilities through downstream reaches and detection probabilities at the Chandler facility and/or McNary Dam.

A2) All PIT-tagged fish in all groups released on the same day had homogeneous and independent survival probabilities below the Chandler facility outfall in 1991 and below the I-82 bridge in 1992. These groups also had homogeneous and independent detection probabilities at McNary Dam.

Assumptions of independence could not be tested with the experimental design and data in this study. Also, in general, homogeneity of survival and detection probabilities within a release group could not be tested but to assume homogeneity seemed reasonable since the fish were released at exactly the same time and location.

Fish released in the Prosser Dam forebay and subsequently diverted into the Chandler Canal could experience differential survival downstream from the Chandler facility outfall and differential detection at McNary Dam than those not diverted, if the two groups did not remix below the outfall. This would violate Assumption Al. The validity of Assumption A1, based on downstream remixing of diverted and undiverted R1 fish, was tested using the Pearson chi-square test of homogeneity for McNary Dam passage distributions (Sokal and Rohlf 1981). This test was based on the following $K \times 2$ contingency table: 
Diverted into Chandler Canal

and detected at the Chandler facility

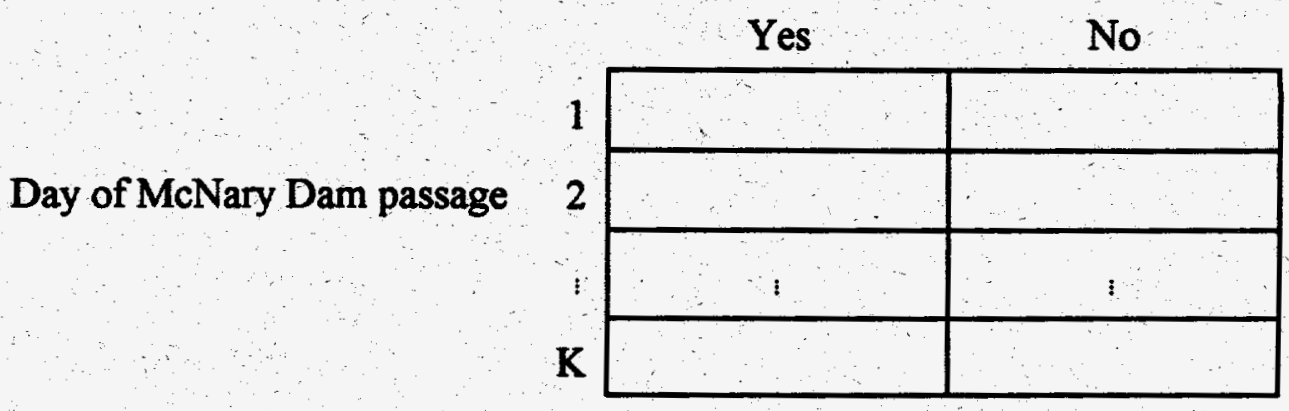

Table entries were the totals of PIT-tagged fish from each subgroup passing McNary Dam on each of $\mathrm{K}$ days ( $\mathrm{K}$ varied considerably between release days over time and years). $\mathrm{P}$-values were determined using a Monte Carlo estimate of a nonparametric exact approach (Mehta and Patel 1992).

Fish that passed through the Chandler facility and were included in the daily facility sample could experience differential survival downstream and differential detection at McNary Dam than those not sampled. This would occur if their survival or behavior was affected by the sampling process or if they did not remix below the outfall. This would also violate Assumption A1. The validity of Assumption A1, based on mixing of sampled and unsampled R1 and R2 fish, was tested using the Pearson chi-square test of homogeneity for McNary Dam passage distributions. The test was based on this $\mathrm{K} \times 2$ contingency table: 
Included in the Chandler

facility sample

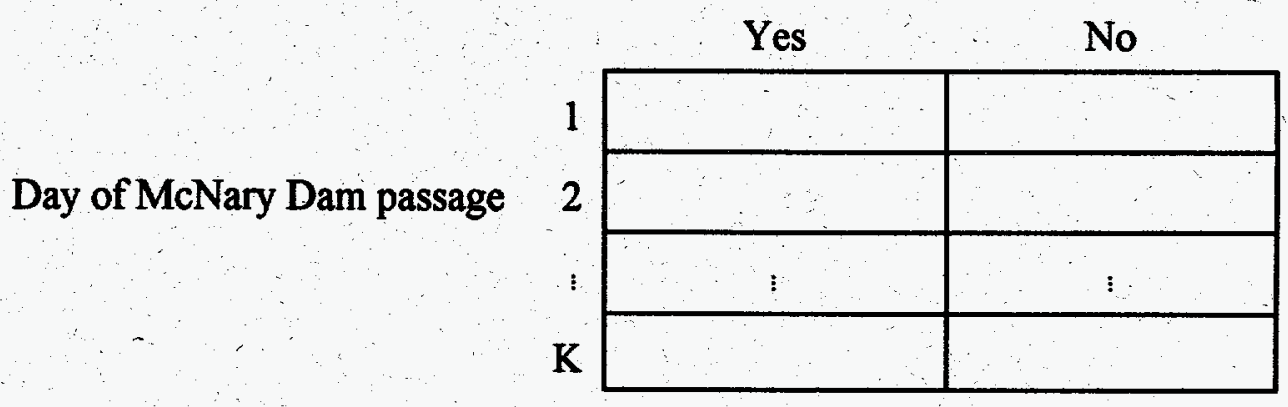

The effect of the sampling process on downstream survival and detection was only tested if the chi-square test was not significant, since a lack of mixing would imply potential differences due to other factors. The test was to compare the proportion of sampled and unsampled fish (all originally detected by the Chandler facility main PIT-tag detector) detected at McNary Dam. The validity of Assumption A1, based on the effect of the Chandler facility sampling process, was tested using a t-test on the ratio of sampled to unsampled McNary Dam detection proportions.

The validity of Assumption A2, based on downstream mixing of all groups released on the same day, was tested using the Pearson chi-square test of homogeneity for McNary Dam passage distributions. This test was based on the following $K \times I$ contingency table where $I=4$ or 1991 and 5 or 6 for 1992 :

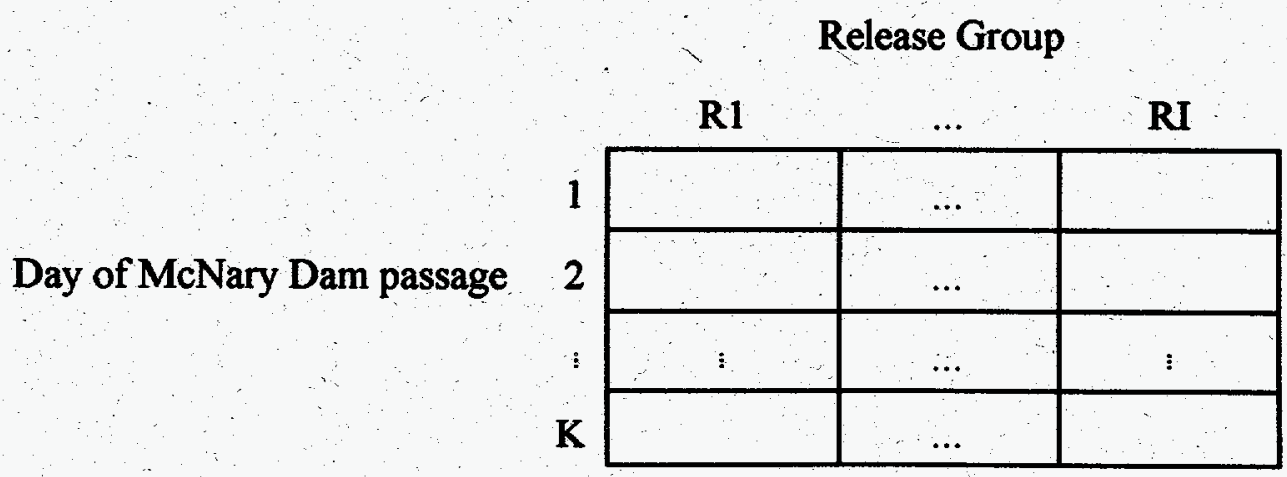


Comparison-wise Error Rate-Each set of chi-square contingency table tests was considered a separate and independent experiment, with each test within the set considered a separate and independent comparison. Significance levels for individual tests were selected to control the comparison-wise Type I error rate, $\alpha$, rather than the experiment-wise Type I error rate. However, when enough multiple tests were done within an experiment with the same null hypothesis, one or more tests were expected to be significant for the comparison-wise $\alpha$ by chance alone. Therefore, if the number of significant tests per experiment was similar to the number expected by chance, the tested assumption was deemed valid for those comparisons and for the experiment. The comparison-wise significance level was set at $\alpha=0.05$ for this study.

\section{Expanded Detection Proportion Estimation}

As previously stated, the maximum likelihood approach to parameter estimation was considered optimum in this study, given the various release locations and PIT-tag detections at both the Chandler facility and McNary Dam. However, limited parameter estimation was possible when survival to or detection at McNary Dam was extremely low. When the PIT-tag detection efficiency of the Chandler facility (P), or of just the main PIT-tag detector, was known or could be estimated, S2 could also be estimated. The expanded detection proportion (EDP) S2 estimate was the proportion of $\mathrm{R} 2$ fish detected by the main and sample detectors (or just the main detector) divided by P (or the main detector efficiency). The EDP and MLE estimates of S2 were compared by examining the ratio, MLE/EDP.

\section{Relative Recapture Estimation}

When the PIT-tag detection efficiency of the Chandler facility (P) or of just the main PITtag detector was unknown or unestimated, but was assumed to be equal between release groups, 
D could be estimated by the relative recapture (RR) method. The RR estimate of $D$ was the proportion of detected R1 fish divided by the proportion of detected R2 fish. However, this estimate was only valid under the assumption that Prosser Dam forebay survival was $100 \%$. The RR and MLE estimates of $D$ were compared by examining the ratio, MLE/RR.

\section{Chandler Facility Main PIT-tag Detector Efficiency}

The maximum likelihood procedure described above was used to estimate overall PIT-tag detection efficiency of the Chandler facility. However, the efficiency of the main PIT-tag detector was estimated independent of the likelihood analyses. This estimate was the proportion of PIT tags detected on the sample PIT-tag detector that had been previously detected on the main detector. This estimate was a lower bound on the Chandler facility PIT-tag detection efficiency and was probably fairly close to the actual facility efficiency since the sample detector only had the potential of detecting the sampled fraction of all PIT-tagged fish.

\section{Survival Relationship with Water Temperature and Flow}

The relationship between fish survival and prevailing biological and environmental conditions was examined by comparing estimated survival in various reaches to the release date and average daily water temperature and flow. Water flow and temperature were taken from the Bureau of Reclamation HYDROMET system at locations PRO (Prosser Dam Reservoir), YRPW (Yakima River below Prosser Dam), and CHCW (Chandler Power Canal) and were averaged over the day of release. Visual inspection of the appropriate scatterplots and/or regression analyses were used for the comparisons. 


\section{Chandler Canal Flow Diversion versus Fish Entrainment}

The functional relationship between the proportion of river flow diverted into the Chandler Canal on the day of release and the MLE of the proportion of fish entrained into the canal (D) was examined by visual inspection of the scatterplot and by regression analyses. The exact regression equations were chosen using three criteria:

1) The equations explained a significant amount of the variability in fish entrainment estimates (i.e., strong correlations which were significantly larger than zero).

2) The equations fit well statistically (i.e., they met assumptions that the regression residuals were randomly scattered around zero and reasonably normally distributed).

3) The equations were fairly mathematically straightforward and biologically logical and understandable.

Additionally, $95 \%$ prediction intervals were calculated for the regression equations to quantify the uncertainty in individual entrainment predictions (Weisberg 1985).

\section{Travel Time}

Minimum and median travel time in hours from release to detection at the Chandler facility main PIT-tag detector was calculated for each $\mathrm{R} 1$ and $\mathrm{R} 2$ release group. Travel time differences were compared between $\mathrm{RT}$ and $\mathrm{R} 2$ on each release day. The travel time statistics were examined to characterize the short-term migrational characteristics of the PIT-tagged fish released over time and between fish released in the Prosser Dam forebay and Chandler Canal at the same time.

Median travel time in days from release to detection at McNary Dam was calculated for all release groups. Maximum differences between median travel times were calculated for groups released on the same day and McNary Dam passage distributions were plotted for the release 
groups on each release day. The passage distributions and median travel times were examined to characterize differences in migrational distributions of PIT-tagged fish between release groups and over time.

\section{RESULTS AND DISCUSSION}

\section{Test Conditions}

Fish for treatment groups were PIT tagged and released 13 April to 23 May 1991 and 3 April to 4 June 1992 (Tables 2 and 3). A total of 26,267 yearling chinook and 8,359 coho salmon were tagged on 35 and 11 dates, respectively ${ }^{2}$. Tagged group sizes varied between days but were generally around 200 in 1991 and 125 in 1992 . Release groups R1-R4 were included on all release days in both years, while R5 was on all 1992 release days and R6 was only on 6 days each in 1992 for yearling chinook and coho salmon.

\section{Quality Control}

Records of 24-hour delayed mortality were not generally kept in 1991. Only three mortalities were noted on the PTAGIS database: one was in release group R1 on 2 May, and the other two were in release group R3 on 17 and 23 April. Overall delayed mortality in 1992 was low at $1.1 \%(204 / 18,328)$ with nearly half of the mortalities occurring in the last three June releases (Table 4). These three release days were not included in maximum likelihood survival and entrainment estimates. Mortality of the remaining test groups was only $0.7 \%(111 / 16,078)$.

\footnotetext{
${ }^{2}$ PIT-tag tagging files were named TERxxyy.ijk, where, $\mathrm{xx}$ was the study year; yyy was the Julian tagging date; $i$ was the release location (e.g., for $R 1, i=1$; note that in $1991 \mathrm{i}=3$ for $R 2$ and $i=2$ for $R 3$ ); $j$ was a letter indexing the release days (e.g., for release $1, j=A$ ); and $\mathrm{k}$ was $\mathrm{A}$ or $\mathrm{C}$ for yearling chinook and coho salmon, respectively.
} 
Table 2. Numbers of yearling chinook and coho salmon PIT tagged at the Chandler facility and released at various locations in 1991. Abbreviations: R1-approximately one $\mathrm{km}$ upstream from Prosser Dam; R2-the headworks of the Chandler Canal; R3-immediately below Prosser Dam; R4-the Chandler facility outfall.

\begin{tabular}{|c|c|c|c|c|}
\hline Release & Rele: & tion & & \\
\hline Date & $\mathrm{R} 1$ & R2 & R3 & R4 \\
\hline Yearling chin & almon & & & \\
\hline 14 April & 150 & 150 & 149 & 150 \\
\hline 15 April & 200 & 200 & 200 & 200 \\
\hline 16 April & 200 & 200 & 200 & 200 \\
\hline 17 April & 200 & 200 & 200 & 200 \\
\hline 22 April & 200 & 200 & 200 & 200 \\
\hline 23 April & 200 & 200 & 199 & 200 \\
\hline 24 April & 200 & 200 & 200 & 201 \\
\hline 25 April & 225 & 225 & 225 & 225 \\
\hline 26. April & 225 & 225 & 225 & 225 \\
\hline 1 May & 225 & 224 & 225 & 225 \\
\hline 2 May & 225 & 225 & 225 & 225 \\
\hline 3 May & 200 & 200 & 200 & 200 \\
\hline 4 May & 250. & 250 & 250 & 250 \\
\hline 5 May & 200 & 200 & 200 & 200 \\
\hline 7 May & 200 & 200 & 200 & 200 \\
\hline Total & 3100 & 3099 & 3098 & 3101 \\
\hline Coho salmon & & & & \\
\hline 16 May & 175 & 176 & 175 & 175 \\
\hline 17 May & 200 & 200 & 200 & 200 \\
\hline 18 May & 200 & 200 & 200 & 200 \\
\hline 21 May & 200 & 200 & 200 & 200 \\
\hline 23 May & 200 & 200 & 199 & 200 \\
\hline Total & 975 & 976 & 974 & 975 \\
\hline Grand Total & 4075 & 4075 & 4072 & 4076 \\
\hline
\end{tabular}


Table 3. Numbers of yearling chinook and coho salmon PIT tagged at the Chandler facility and released at various locations in 1992. Abbreviations: Rl-approximately one $\mathrm{km}$ upstream from Prosser Dam; R2-the headworks of the Chandler Canal; R3-immediately below Prosser Dam; R4-the Chandler facility outfall; R5-the I-82 bridge; R6immediately below the main PIT-tag detector in the Chandler facility.

\begin{tabular}{|c|c|c|c|c|c|c|}
\hline Release & Rele & ocatio & & & & \\
\hline Date & R1 & $\mathbf{R} 2$ & R3 & $\mathbf{R} 4$ & R5 & R6 \\
\hline Yearling chin & almon & & & & & \\
\hline 3 April & 125 & 125 & 125 & 125 & 125 & \\
\hline 4 April & 175 & 175 & 175 & 175 & 175 & \\
\hline 5 April & 150 & 154 & 149 & 150 & 150 & \\
\hline 6 April & 150 & 150 & 150 & 150 & 150 & \\
\hline 7 April & 150 & 150 & 150 & 150 & 150 & \\
\hline 14 April & 125 & 125 & 125 & 125 & 125 & \\
\hline 16 April & 125 & 125 & 125 & 125 & 125 & \\
\hline 18 April & 125 & 125 & 125 & 125 & 125 & \\
\hline 20 April & 125 & 125 & 125 & 125 & 125 & 125 \\
\hline 21 April & 125 & 125 & 125 & 125 & 125 & 125 \\
\hline 22 April & 125 & 125 & 125 & 125 & 125 & 125 \\
\hline 12 May & 125 & 125 & 124 & 124 & 125 & \\
\hline 13 May & 123 & 125 & 124 & 125 & 124 & \\
\hline $21 \mathrm{May}$ & 125 & 125 & 125 & 125 & 125 & \\
\hline 22 May & 125 & 125 & 125 & 125 & 125 & \\
\hline 23 May & 125 & 124 & 125 & 124 & 124 & \\
\hline 27 May & 125 & 125 & 125 & 125 & 125 & \\
\hline 2 June & 125 & 125 & 125 & 125 & 125 & 125 \\
\hline 3 June & 125 & 125 & 125 & 125 & 125 & 125 \\
\hline 4 June & 125 & 125 & 125 & 125 & 125 & 125 \\
\hline Total & 2623 & 2628 & 2622 & 2623 & 2623 & 750 \\
\hline Coho salmon & & & & & & \\
\hline 28 April & 125 & 125 & 125 & 125 & 125 & 125 \\
\hline 29 April & 125 & 125 & 125 & 125 & 125 & 125 \\
\hline 30 April & 125 & 125 & 125 & 125 & 125 & 84 \\
\hline 5 May & 125 & 125 & 125 & 125 & 125 & 125 \\
\hline 6 May & 125 & 125 & 125 & 125 & 125 & 125 \\
\hline 7 May & 125 & 125 & 125 & 125 & 125 & 125 \\
\hline Total & 750 & 750 & 750 & 750 & 750 & 709 \\
\hline Grand Total & 3373 & 3378 & 3372 & 3373 & 3373 & 1459 \\
\hline
\end{tabular}


Table 4. Numbers of 24-hour delayed mortalities for the various release groups of yearling chinook and coho salmon PIT tagged at the Chandler facility in 1992. Abbreviations: R1-approximately one $\mathrm{km}$ upstream from Prosser Dam; R2-the headworks of the Chandler Canal; R3-immediately below Prosser Dam; R4-the Chandler facility outfall; R5-the I-82 bridge; R6-immediately below the main PIT-tag detector in the Chandler facility.

\begin{tabular}{|c|c|c|c|c|c|c|}
\hline Release & Relea & cation & & & & \\
\hline Date & R1 & $\mathbf{R} 2$ & R3 & R4 & R5 & R6 \\
\hline$\overline{3 \text { April }}$ & 1 & & & & & \\
\hline 4 April & & 2 & & & & \\
\hline 5 April & & & 1 & & & \\
\hline 6 April & $\therefore$ & & & & & \\
\hline 7 April & & & & & & \\
\hline 14 April & 1 & & & & 1 & \\
\hline 16 April & 2 & 1 & 3 & 3 & 1 & \\
\hline 18 April & & & 1 & & & \\
\hline 20 April & & 1 & 6 & & & \\
\hline 21 April & & 1 & & & & \\
\hline 22 April & 7 & & 3 & & & \\
\hline 28 April & 1 & & & & 1 & \\
\hline 29 April & & 6 & 2 & $\cdots$ & 1 & 1 \\
\hline 30 April & & & & & & \\
\hline 5 May & & & & & & \\
\hline 6 May & & & & & & \\
\hline 7 May & & & & & & \\
\hline 12 May & 3 & 4 & 14 & 4 & 6 & \\
\hline 13 May & 1 & 1 & & & 4 & \\
\hline 21 May & & & 3 & & $\begin{array}{l}7 \\
6\end{array}$ & \\
\hline 22 May & 1 & 3 & 1 & & 6 & \\
\hline $\begin{array}{l}23 \text { May } \\
27 \text { May }\end{array}$ & 1 & 3 & 1 & 1 & 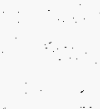 & \\
\hline Total & 18 & 22 & 35 & 8 & 27 & 1 \\
\hline 2 June & 2 & 2 & 1 & 3 & 10 & 3 \\
\hline 3 June & 4 & 1 & 5 & 3 & 2 & 6 \\
\hline 4 June & 13 & 6 & 13 & 10 & 7 & 2 \\
\hline Total & 19 & 9 & 19 & 16 & 19 & 11 \\
\hline Grand Total & 37 & 31 & 54 & 24 & 46 & 12 \\
\hline
\end{tabular}


We assumed that the unreported 24-hour delayed mortality in 1991 was similar to that observed in 1992, and that it was random with respect to release group. The resultant unknown bias of 1991 parameter estimates was considered trivial and would have only affected recapture probabilities and precision estimates.

There were very few PIT-tag observation anomalies for both years. Only 12 fish in release groups R3-R6 were erroneously detected at the Chandler facility, and no fish were detected at McNary Dam before having been detected at the Chandler facility. Two fish classified as mortalities were detected at the Chandler facility, and three fish were observed before release; PIT-tag records for theses fish were deleted from the observation files.

Careful examination of the data and the statistics generated in survival and travel-time analyses indicated that the main PIT-tag detector at the Chandler facility malfunctioned or was inoperative during important passage periods on 7 May 1991, 7 April 1992, and 12 May 1992. This led to a potentially serious bias in statistical estimates (see Appendix 2). Therefore, data and statistics from these days are not presented further in this report, except for travel-time analyses to McNary Dam. Similar detector or Chandler facility problems may have existed on other dates as well but could not be adequately documented.

Very few PIT-tagged fish from the three June 1992 releases were detected at McNary Dam (Appendix Table 3j). Parameter estimates for these releases from the maximum likelihood procedure were unattainable. Sufficient fish were detected at the Chandler facility for PIT-tag detector efficiency estimation using sample detections as well as Chandler Canal survival estimates based on expanded $\mathbf{R} 2$ detections at the facility. Relative recapture estimates of the proportion of fish entrained into the Chandler Canal were also possible. However, the RR 
method required $100 \%$ survival in the Prosser Dam forebay. While this occurred on average for all other releases in which MLE Prosser Dam forebay survival estimates were calculated, mean daily water temperature and flow in the forebay for these June 1992 releases were outside the ranges observed for all other releases. Therefore, inference of $100 \%$ Prosser Dam forebay survival for these late releases was not statistically prudent, and entrainment estimates were not made. Data from these releases were also not used in McNary Dam travel-time analyses.

The release date for the 1 May 1991 R1-R3 releases was incorrectly reported to PTAGIS as 30 April 1991. Release times for the 20 April $R 1$ and $R 2$ releases and the 21 May $R 1$ release in 1992 appeared to be reported as 3 and 1 hours too early, respectively, based on examination of travel-time data to the Chandler facility main PIT-tag detector. Release dates and times were not reported for the 13 May 1992 R3 release and the 30 April 1992 R5 and R6 releases. The release times used in travel time analyses were estimated from the other release groups on the appropriate day.

\section{Tests of Assumptions}

\section{Assumption A1}

None of the chi-square tests to assess mixing downstream from the Chandler facility outfall for detected and undetected fish from $R 1$ releases were significant at the 0.05 comparisonwise error rate (Table 5 and Appendix Tables 1a-1e). Due to very small or zero sample sizes for Rl fish not detected at the Chandler facility, no chi-square tests were done for groups released in May 1991 or during all of 1992 . The tests that were done, therefore, were quite limited as an overall assessment of the validity of Assumption A1, particularly for coho salmon, which had no valid tests. However, for most of the groups not tested, a very high proportion of tagged fish 
Table 5. Tests of homogeneity of McNary Dam passage distributions for yearling chinook salmon released one $\mathrm{km}$ above Prosser Dam and detected or not detected at the Chandler facility. P-values calculated using Monte Carlo approximation of the exact method. No tests conducted in May 1991 or all of 1992 due to small sample sizes of undetected fish.

\begin{tabular}{|c|c|c|c|}
\hline $\begin{array}{l}\text { Release } \\
\text { Dete (1991) }\end{array}$ & $x^{2}$ & $\begin{array}{l}\text { es of } \\
\text { Freedom }\end{array}$ & P-yalue \\
\hline 14 April & 15.11 & 16 & 0.5925 \\
\hline 15 April & 16.78 & 21 & 0.8317 \\
\hline 16 April & 20.36 & 20 & 0.4555 \\
\hline 17 April & 20.82 & 19 & 0.3505 \\
\hline 22 April & 13.89 & 16 & 0.6532 \\
\hline 23 April & 16.43 & 17 & 0.5325 \\
\hline 24 April & 12.55 & 16. & 0.7783 \\
\hline 25 April & 20.29 & 17 & 0.2325 \\
\hline 26 April & 22.09 & 15 & 0.0897 \\
\hline
\end{tabular}


were estimated to be entrained into the Chandler Canal. Thus, discussion of the validity of this assumption based on these $\mathrm{R} 1$ mixing tests is moot.

For yearling chinook salmon in 1991 and 1992, only 1 of 28 chi-square tests of mixing downstream from the Chandler facility outfall for $R 1$ and $R 2$ fish, sampled and unsampled at the facility, was significant at the $\alpha=0.05$ comparison-wise error rate (Tables 6 and 7 and Appendix Tables 2a-2c and 2e). (Note that tests were not done for releases after 21 May 1992 due to very small sample sizes.) Since about $1(28 \times 0.05=1.4)$ of the 28 tests would be expected to be significant by chance, the 3 April 1992 result was not considered indicative of a failure of Assumption A1.

All of the 1991 and two of the six 1992 coho salmon chi-square tests were highly significant (Tables 6 and 7 and Appendix Tables $2 \mathrm{~b}$ and 2d). The significant results appeared to be due to a 1-day shift in the McNary Dam passage distributions, which were quite compact. Survival and detection probabilities probably did not vary significantly over such short time periods. Therefore, Assumption Al was most likely not substantially violated.

The relative proportion of Chandler facility sampled to unsampled $R 1$ and $R 2$ fish detected at McNary Dam was significantly lower than 1.00 for yearling chinook salmon in 1991 at 0.92 $(\mathrm{SE}=0.02)(\mathrm{t}=3.38, \mathrm{df}=12, \mathrm{P}=0.0055$; Table 8$)$. This implied an $8 \%$ higher mortality for sampled fish in 1991. This proportion in early April 1992 was not significantly different from 1.00 at $1.08(\mathrm{SE}=0.09)(\mathrm{t}=0.84, \mathrm{df}=3, \mathrm{P}=0.4608)$, but was significantly lower after mid-April at $0.77(\mathrm{SE}=0.04)(\mathrm{t}=5.83, \mathrm{df}=5, \mathrm{P}=0.0021)$. (Note that tests were not done for releases in May 1992 due to very small sample sizes.) This implied a 24\% higher mortality for sampled fish 
Table 6. Tests of homogeneity of McNary Dam passage distributions for yearling chinook and coho salmon released one $\mathrm{km}$ above Prosser Dam or at the headworks of the Chandler Canal in 1991 and sampled or not sampled at the Chandler facility. P-values calculated using Monte Carlo approximation of the exact method.

\begin{tabular}{|c|c|c|c|}
\hline $\begin{array}{l}\text { Release } \\
\text { Date } \\
\end{array}$ & $x^{2}$ & $\begin{array}{l}\text { Degrees of } \\
\text { Freedom }\end{array}$ & P-value \\
\hline \multicolumn{4}{|c|}{ Yearling chinook salmon } \\
\hline 14 April & 18.07 & 22 & 0.7634 \\
\hline 15 April & 19.00 & 24 & 0.7471 \\
\hline 16 April & 21.05 & 22 & 0.5372 \\
\hline 17 April & 25.46 & 21 & 0.2057 \\
\hline 22 April & 15.26 & 19 & 0.7618 \\
\hline 23 April & 17.29 & 18 & 0.5353 \\
\hline 24 April & 15.98 & 17 & 0.5515 \\
\hline 25 April & 14.42 & 18 & 0.7571 \\
\hline 26 April & 13.63 & 16 & 0.6547 \\
\hline 1 May & 16.83 & 15 & 0.3249 \\
\hline 2 May & 22.35 & 15 & 0.0597 \\
\hline 3 May & 16.05 & 13 & 0.2284 \\
\hline 4 May & 15.65 & 13 & 0.2581 \\
\hline 5 May & 11.76 & 11 & 0.3717 \\
\hline 7 May & 14.56 & 12 & 0.2672 \\
\hline \multicolumn{4}{|c|}{ Coho salmon } \\
\hline 16 May & 43.46 & 7 & $<0.0001$ \\
\hline 17 May & 28.68 & 9 & 0.0002 \\
\hline 18 May & 48.23 & 8 & $<0.0001$ \\
\hline 21 May & 24.09 & 5 & 0.0001 \\
\hline 23 May & 53.95 & 6. & $<0.0001$ \\
\hline
\end{tabular}


Table 7. Tests of homogeneity of McNary Dam passage distributions for yearling chinook and coho salmon released one $\mathrm{km}$ above Prosser Dam or at the headworks of the Chandler Canal in 1992 and sampled or not sampled at the Chandler facility. P-values calculated using Monte Carlo approximation of the exact method.

\begin{tabular}{llll}
\hline Release & & & \\
Date & $\chi^{2}$ & $\begin{array}{l}\text { Degrees of } \\
\text { Freedom }\end{array}$ & P-value \\
\hline Yearling chinook salmon & & & \\
3 April & 35.31 & 24 & 0.0273 \\
4 April & 9.02 & 22 & 0.9978 \\
5 April & 22.62 & 22 & 0.4297 \\
6 April & 22.47 & 20 & 0.3084 \\
7 April & 13.87 & 17 & 0.7534 \\
14 April & 16.38 & 23 & 0.9128 \\
16 April & 22.63 & 21 & 0.3624 \\
18 April & 18.12 & 19 & 0.5549 \\
20 April & 23.16 & 19 & 0.2340 \\
21 April & 9.54 & 16 & 0.9323 \\
22 April & 14.99 & 17 & 0.6370 \\
12 May & 9.41 & 12 & 0.9046 \\
13 May & 12.16 & 15 & 0.8469 \\
21 May & 14.40 & 11 & 0.3186 \\
22 May & -2 & & \\
23 May & - & & \\
27 May & - & & \\
2 June & - & & \\
3 June & - & & \\
4 June & - & & \\
Coho salmon & & & \\
28 April & & & \\
29 April & 14.33 & 11 & 0.1967 \\
30 April & 15.75 & 13 & 0.2480 \\
5 May & 9.84 & 12 & 0.6183 \\
6 May & 14.33 & 10 & 0.1221 \\
7 May & 26.91 & 14 & 0.0043 \\
\hline & 31.13 & 17 & 0.0142 \\
\hline
\end{tabular}

Dashes indicate test not done due to very small sample sizes. 
Table 8. The relative proportion detected at McNary Dam (MCN) of fish sampled at the Chandler facility (CHF) to unsampled which were released one $\mathrm{km}$ above Prosser Dam or at the headworks of the Chandler Canal in 1991 and 1992.

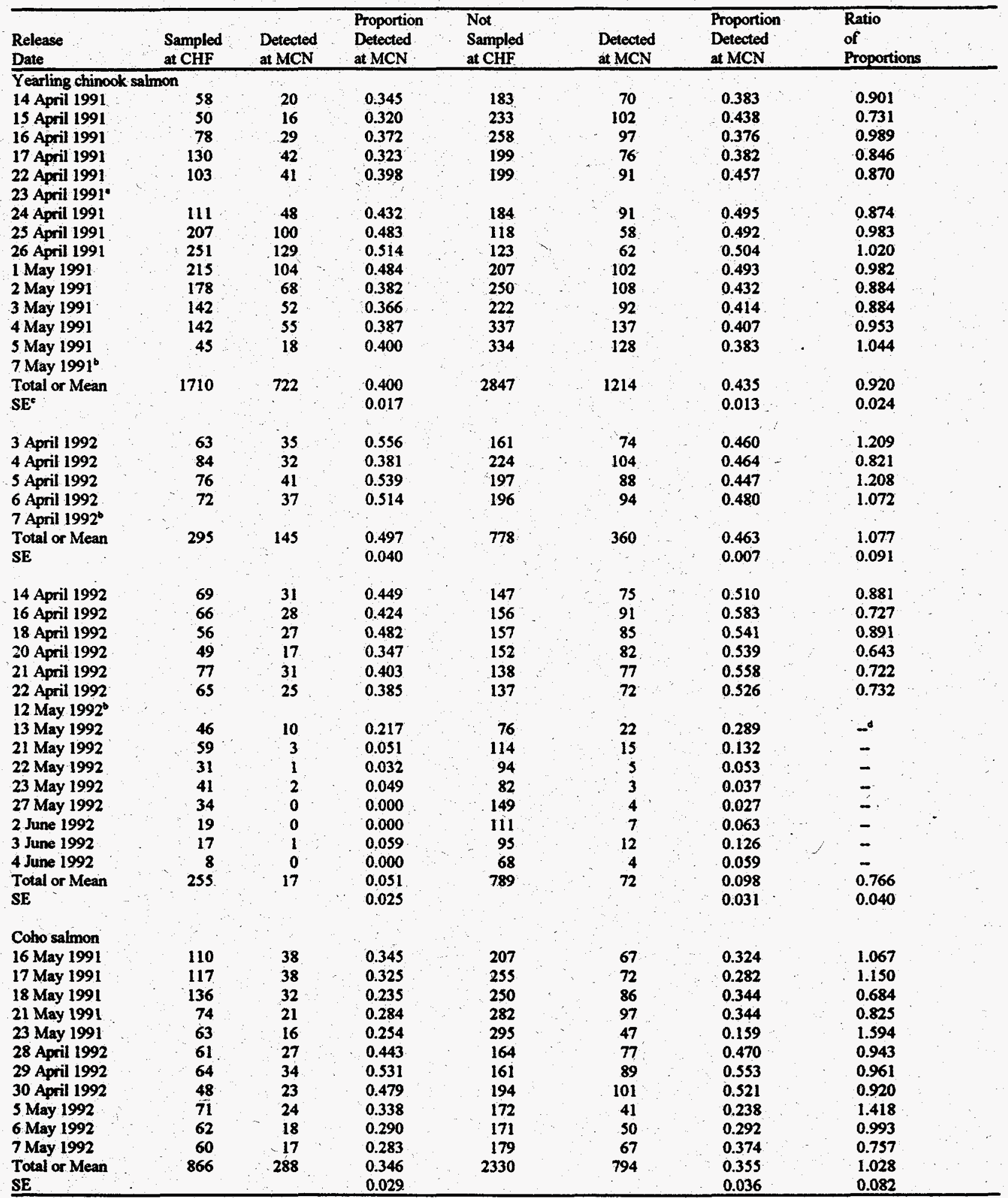

No estimate calculated due to poor mixing at McNary Dam.

- No estimate calculated due to Chandler facility PIT-tag detector malfunction

- SE = Standard Error of the Total or Mean.

- Dashes indicate ratio not calculated due to small sample sizes. 
in 1992 in mid-to-late April. Chandler facility survival estimates were adjusted (see later sections) for this violation of Assumption A1.

For coho salmon in both years, the relative proportion of fish sampled at the Chandler facility to those unsampled for R1 and R2 groups detected at McNary Dam was not significantly different from 1.00 at $1.03(\mathrm{SE}=0.08)(\mathrm{t}=0.35, \mathrm{df}=10, \mathrm{P}=0.7372$; Table 8). Therefore, the sampling procedure apparently did not cause a violation of Assumption A1 for coho salmon.

\section{Assumption A2}

Only 3 of 32 chi-square tests for yearling chinook salmon mixing at McNary Dam were significant at the $\alpha=0.05$ comparison-wise error rate (Tables 9 and 10 and Appendix Tables 3a$3 \mathrm{c}, 3 \mathrm{e}, 3 \mathrm{f}, 3 \mathrm{i}$, and $3 \mathrm{j})$. However, about $2(32 \times 0.05=1.6)$ of the 32 tests would be expected to be significant by chance. Therefore, the 14 April 1991 and 5 April 1992 results were not considered indicative of a failure of Assumption A2.

The highly significant result for 23 April $1991(P=0.0040)$, however, implied a lack of mixing for that group of releases. Comparison of the median travel times and visual inspection of the McNary Dam passage distributions for that release indicated R1 and R2 fish passed McNary Dam 1 day later than R4 fish and 2-3 days later than R3 fish. River conditions at McNary Dam fluctuated somewhat over the time period when fish from these groups were arriving at the dam but did not exhibit a strong trend through time (USACE 1991). Due to the potential violation of Assumption A2, data were omitted from the maximum likelihood analysis for this release day. For 23 April 1991, the RR estimate was used for the entrainment estimate and the EDP estimate was used for the Chandler Canal survival estimate. 
Table 9. Tests of homogeneity of McNary Dam passage distributions for yearling chinook and coho salmon released one $\mathrm{km}$ above Prosser Dam, at the headworks of the Chandler Canal, immediately below Prosser Dam, or at the Chandler facility outfall in 1991. Pvalues calculated using Monte Carlo approximation of the exact method.

\begin{tabular}{llll}
\hline $\begin{array}{l}\text { Release } \\
\text { Date }\end{array}$ & $\chi^{2}$ & $\begin{array}{l}\text { Degrees of } \\
\text { Freedom }\end{array}$ & P-value \\
\hline Yearling chinook salmon & & & \\
14 April & 100.4 & 81 & 0.0461 \\
15 April & 86.2 & 84 & 0.4100 \\
16 April & 84.0 & 75 & 0.1915 \\
17 April & 91.0 & 78 & 0.1192 \\
22 April & 61.2 & 66 & 0.6851 \\
23 April & 86.4 & 57 & 0.0040 \\
24 April & 66.9 & 63 & 0.3176 \\
25 April & 63.8 & 63 & 0.4519 \\
26 April & 63.7 & 57 & 0.2375 \\
1 May & 57.8 & 51 & 0.2127 \\
2 May & 52.2 & 48 & 0.2979 \\
3 May & 54.4 & 42 & 0.0643 \\
4 May & 54.1 & 42 & 0.0787 \\
5 May & 51.3 & 42 & 0.1362 \\
7 May & 62.4 & 51 & 0.0941 \\
& & & \\
Coho salmon & & & \\
16 May & 62.2 & 36 & 0.0006 \\
17 May & 52.1 & 39 & 0.0208 \\
18 May & 56.2 & 21 & $<0.0001$ \\
21 May & 28.7 & 12 & 0.0023 \\
23 May & 36.9 & 15 & 0.0003 \\
\hline
\end{tabular}


Table 10. Tests of homogeneity of McNary Dam passage distributions for yearling chinook and coho salmon released one $\mathrm{km}$ above Prosser Dam, at the headworks of the Chandler Canal, immediately below Prosser Dam, at the Chandler facility outfall, at the I-82 bridge, or immediately below the main PIT-tag detector in the Chandler facility in 1992. P-values calculated using Monte Carlo approximation of the exact method.

\begin{tabular}{|c|c|c|c|}
\hline $\begin{array}{l}\text { Release } \\
\text { Date }\end{array}$ & $x^{2}$ & $\begin{array}{l}\text { Degrees of } \\
\text { Freedom }\end{array}$ & $\mathrm{P}$-value \\
\hline \multicolumn{4}{|c|}{ Yearling chinook salmon } \\
\hline 3 April & 103.1 & 112 & 0.7537 \\
\hline 4 April & 130.5 & 112 & 0.0809 \\
\hline 5 April & 130.7 & 104 & 0.0247 \\
\hline 6 April & 89.9 & 92 & 0.5553 \\
\hline 7 April & 106.5 & 108 & 0.5337 \\
\hline 14 April & 106.4 & 116 & 0.7756 \\
\hline 16 April & 100.8 & 96 & 0.3327 \\
\hline 18 April & 111.6 & 100 & 0.1673 \\
\hline 20 April & 121.9 & 110 & 0.1798 \\
\hline 21 April & 112.1 & 125 & 0.8371 \\
\hline 22 April & 99.7 & 100 & 0.4890 \\
\hline 12 May & 118,6 & 108 & 0.2179 \\
\hline 13 May & 125.1 & 128 & 0.5821 \\
\hline 21 May & 75.6 & 84 & 0.8362 \\
\hline 22 May & 63.8 & 56 & 0.2481 \\
\hline 23 May & 44.7 & 44 & 0.4510 \\
\hline 27 May & 53.8 & 52 & 0.5092 \\
\hline 2 June & $--^{2}$ & & \\
\hline 3 June & - & & \\
\hline 4 June & - & & \\
\hline \multicolumn{4}{|c|}{ Coho salmon } \\
\hline 28 April & 75.0 & 85 & 0.8478 \\
\hline 29 April & 98.0 & 95 & 0.3725 \\
\hline 30 April & 96.3 & 85 & 0.1379 \\
\hline 5 May & 75.2 & 85 & 0.8407 \\
\hline 6 May & 126.1 & 115 & 0.1432 \\
\hline 7 May & 101.2 & 95 & 0.2712 \\
\hline
\end{tabular}

${ }^{2}$ Dashes indicate test not done due to very small sample sizes 
All of the 1991 coho salmon chi-square mixing tests were highly significant, while all of the 1992 tests were not (Tables 9 and 10 and Appendix Tables 3d, 3g, and 3h). Nearly all fish from all groups released on the same day in 1991 were detected over a 3- to 4-day time period, whereas the distributions in 1992 were much more protracted. The significant chi-square values reflected fluctuations in McNary Dam passage over short time periods, with R1 or R2 releases generally passing less than 1 day later than R3 and R4. Survival and detection probabilities probably did not vary significantly over such short time periods. Therefore, Assumption A2 was most likely not violated by the lack of mixing found in 1991 .

\section{Survival}

\section{Estimates}

Maximum likelihood estimates of survival (S1-S4, SA, SM1, and SM2) for the various reaches were obtained using the observed detection history totals (Appendix Tables 4 and 5). Initial MOM estimates for the iterative likelihood solutions are shown in Appendix Tables 6 and 7. Estimated sampling error precision of the daily estimates (i.e., standard errors) are listed in Appendix Tables 8 and 9.

Estimated mean survival in the 1-km reach above Prosser Dam was approximately $100 \%$ across years and species (Tables 11 and 12). Mean estimates ranged between 97.3 and $106.2 \%$ with standard errors between 0.8 and $2.1 \%$. While true survival must be less than or equal to $100 \%$, estimated survivals from the likelihood analyses used for this study were assumed to be randomly distributed about the true survival and were not similarly constrained. Therefore, if true survivals were at or near $100 \%$, it was reasonable to have several estimates greater than $100 \%$ for 
Table 11. Parameter estimates for maximum likelihood analyses in 1991. Abbreviations: S1Prosser Dam forebay survival; S2-Chandler Canal survival; S3-Prosser Dam to the Chandler facility outfall survival; SM1-Chandler facility outfall to McNary Dam survival and detection at McNary Dam; D-diversion proportion into the Chandler Canal; SA-Chandler facility to outfall survival; P-detection proportion at the Chandler facility; SE-standard error.

\begin{tabular}{|c|c|c|c|c|c|c|c|}
\hline $\begin{array}{l}\text { Release } \\
\text { Date }\end{array}$ & S1 & S2 & S3 & SM1 & D & SA & $\mathbf{P}$ \\
\hline \multicolumn{8}{|c|}{ Yearling chinook salmon } \\
\hline 14 April & 0.949 & 0.987 & 0.957 & 0.467 & 0.670 & 0.800 & $10^{2}$ \\
\hline 15 April & 1.030 & 0.984 & 0.957 & 0.470 & 0.460 & 0.887 & 0.976 \\
\hline 16 April & 1.031 & 0.990 & 1.012 & 0.405 & 0.681 & 0.931 & 1. \\
\hline 17 April & 0.962 & 0.969 & 1.282 & 0.425 & 0.779 & 0.841 & 0.985 \\
\hline 22 April & 1.010 & 0.945 & 1.247 & 0.365 & 0.597 & 1.203 & 1. \\
\hline \multicolumn{8}{|l|}{23 April } \\
\hline 24 April & 1.018 & 0.986 & 1.095 & 0.443 & 0.509 & 1.061 & 0.989 \\
\hline 25 April & 0.979 & 0.964 & 0.915 & 0.524 & 0.518 & 0.933 & 1. \\
\hline 26 April & 0.973 & 0.977 & 0.991 & 0.520 & 0.748 & 0.985 & 0.991 \\
\hline 1 May & 1.030 & 0.947 & 1.096 & 0.462 & 0.966 & 1.054 & $1 \ldots$ \\
\hline 2 May & 0.972 & 0.973 & 1.000 & 0.520 & 0.991 & 0.787 & 1. \\
\hline 3 May & 1.022 & 0.958 & 0.989 & 0.475 & 0.916 & 0.828 & 0.987 \\
\hline 4 May & 0.963 & 0.992 & 1.026 & 0.460 & 1.008 & 0.871 & 0.980 \\
\hline 5 May & 0.989 & 0.997 & 0.959 & 0.485 & 1.022 & 0.798 & 0.948 \\
\hline \multicolumn{8}{|l|}{7 Mayc $^{\circ}$} \\
\hline Mean & 0.994 & 0.974 & 1.041 & 0.463 & 0.759 & 0.921 & $0.979^{d}$ \\
\hline SE & 0.008 & 0.005 & 0.031 & 0.013 & 0.057 & 0.035 & 0.006 \\
\hline \multicolumn{8}{|c|}{ Coho salmon } \\
\hline 16 May & 0.991 & 0.978 & 0.953 & 0.411 & 0.925 & 0.793 & 0.982 \\
\hline 17 May & 1.013 & 0.985 & 1.018 & 0.275 & 0.877 & 1.075 & 1. \\
\hline 18 May & 0.975 & 0.980 & 1.090 & 0.335 & 1. & 0.913 & 1. \\
\hline 21 May & 0.931 & 1.005 & 0.813 & 0.375 & 0.873 & 0.877 & 0.985 \\
\hline 23 May & 0.958 & 0.988 & 1.382 & 0.170 & 0.908 & 1.032 & 0.971 \\
\hline Mean & 0.973 & 0.987 & 1.051 & 0.313 & $0.896^{d}$ & 0.938 & $0.979^{d}$ \\
\hline SE & 0.014 & 0.005 & 0.094 & 0.042 & 0.013 & 0.052 & 0.004 \\
\hline
\end{tabular}

- Parameter estimate was assumed to be 1.000 .

b No estimates calculated due to poor mixing at McNary Dam.

c No estimates calculated due to Chandler facility PIT-tag detector malfunction.

- Mean does not include assumed $P=1.000$ estimates. 
Table 12. Parameter estimates for maximum likelihood analyses in 1992. Abbreviations: SIProsser Dam forebay survival; S2-Chandler Canal survival; S3-Prosser Dam to the Chandler facility outfall survival; S4-Chandler facility outfall to the I-82 bridge survival; SM2-I-82 bridge to McNary Dam survival and detection at McNary Dam; Ddiversion proportion into the Chandler Canal; SA-Chandler facility to outfall survival; P-detection proportion at the Chandler facility; SE-standard error.

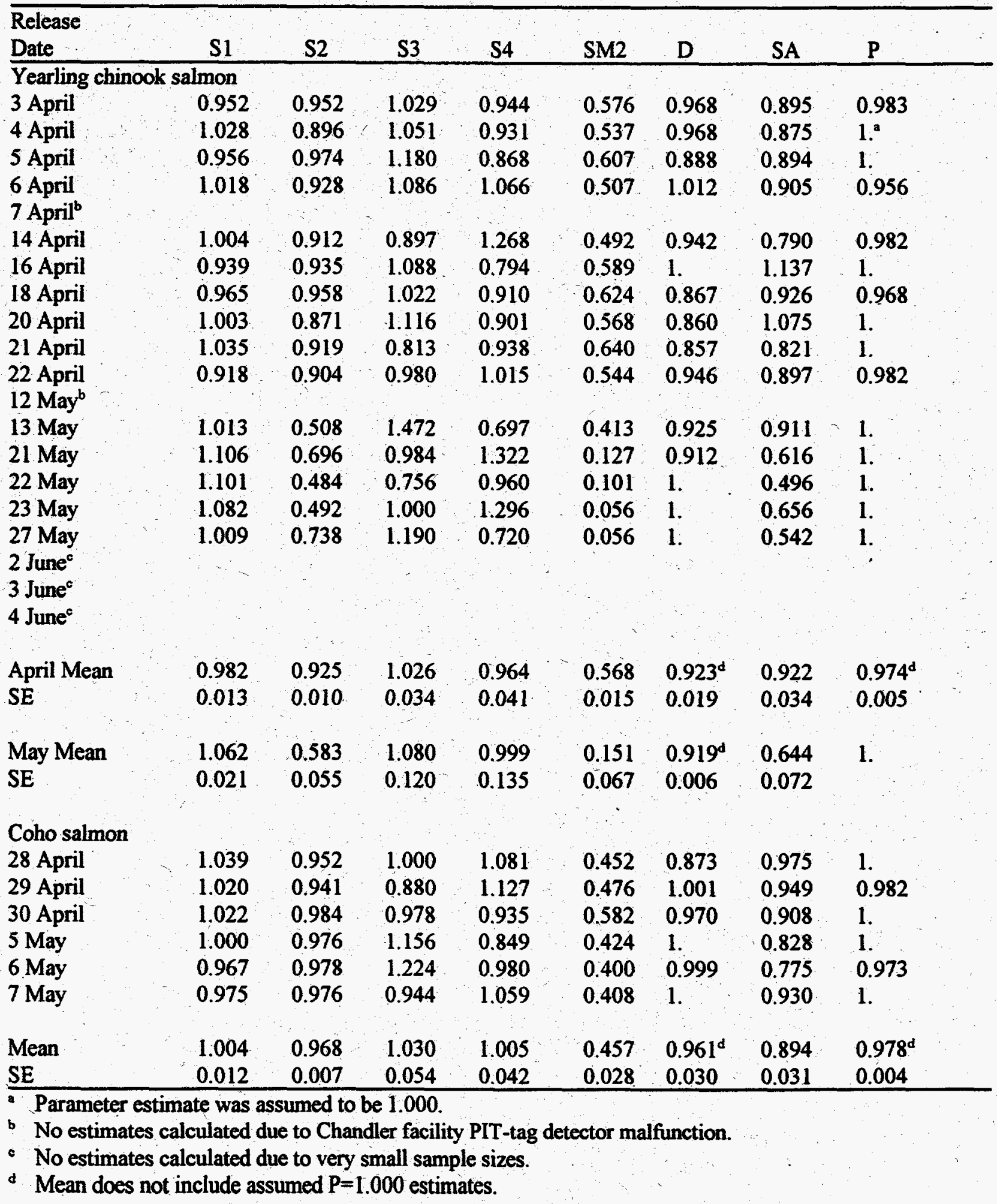


individual releases, and often for the overall average. However, the average estimate was expected to be within two standard errors of $100 \%$. This was not the case for the mean S1 survival for yearling chinook salmon in May 1992 and indicated a possible lack of fit or failure of the assumptions of the likelihood model for those releases. However, this low survival estimate was most likely related to low recapture rates at McNary Dam.

The estimated mean survivals in 1991 of $97.1(\mathrm{SE}=0.5 \%)$ and $98.7 \%(\mathrm{SE}=0.05 \%)$ for yearling chinook and coho salmon, respectively from the entrance of the Chandler Canal to the main facility PIT-tag detector were high (Table 11). Fairly high survival of $92.5(\mathrm{SE}=1.0 \%)$ and $96.8 \%(\mathrm{SE}=0.7 \%)$ for yearling chinook and coho salmon, respectively was estimated in 1992 before 12 May (Table 12). However, yearling chinook mean survival fell to $58.3 \%$ (SE $=5.5 \%$ ) after 12 May and to $47.7 \%(\mathrm{SE}=5.0 \%)$ in June (EDP estimates in Table 14 used in June).

For the reach in the Yakima River from the tailrace of Prosser Dam to the Chandler facility outfall, estimated mean survival exceeded $100 \%$ for both years and species and ranged from 102.6 to $108.0 \%$ (Tables 11 and 12). However, standard errors ranged between 3.1 and $12.0 \%$, implying actual survival was around $100 \%$. The high variation in estimates appeared random over time and was a result of small sample sizes and/or recapture rates at McNary Dam. This was particularly true after 12 May 1992.

Separate survival estimates for the reach from the Chandler facility outfall to the I-82 bridge were only available for 1992. Mean survival was high for both species, averaging 96.4 (SE $=4.1 \%)$ and $99.9 \%(\mathrm{SE}=13.5)$ for yearling chinook salmon in April and May, respectively, and $100.5 \%(\mathrm{SE}=4.2 \%)$ for coho salmon (Table 12). The large standard errors reflected small sample sizes or low recapture rates at McNary Dam, particularly after 12 May. 
Mean survival in the short reach between the main PIT-tag detector in the Chandler juvenile facility and the outfall back into the Yakima River was estimated at $92.1 \%(\mathrm{SE}=3.5 \%)$ in 1991 for yearling chinook salmon and $93.8(\mathrm{SE}=5.2 \%)$ and $89.4 \%(\mathrm{SE}=3.1 \%)$ for coho salmon in 1991 and 1992, respectively (Tables 11 and 12). The yearling chinook salmon estimate included an estimated $8 \%$ mortality due to the sampling process at the facility. The adjusted overall 1991 survival estimate for yearling chinook salmon that passed through the facility and outfall but were not sampled was $94.6 \%(\mathrm{SE}=3.6 \%$; Table 13). Mean survival results for yearling chinook salmon in 1992 were fairly complicated (Table 12). In early April, survival averaged $89.2 \%(\mathrm{SE}=0.6 \%)$ with no detectable mortality due to the sampling process. Later in April, it averaged $94.1 \%(\mathrm{SE}=5.6 \%)$ with nearly all the mortality attributed to the sampling process. The adjusted mean was $101.4 \%(\mathrm{SE}=6.6 \%)$. In May, mean survival dropped to $64.4 \%$ ( $\mathrm{SE}=\mathbf{7 . 2 \%}$ ), but the effect of the sampling process on this low survival could not be estimated. The large standard errors reflected small sample sizes and/or recapture rates at McNary Dam.

Virtually no salmonid mortality was observed in the Yakima River from $1 \mathrm{~km}$ above Prosser Dam to the I-82 bridge over the time and river conditions tested for both yearling chinook and coho salmon. Passage through the Chandler Canal and facility and back into the Yakima River resulted in roughly $11 \%$ mortality for coho salmon and $7-16 \%$ mortality for yearling chinook salmon, except in late May 1992 when it averaged $63 \%$. For coho salmon, most of the mortality occurred in the segment between the Chandler facility entrance and its outfall and was not a result of the sampling process. For yearling chinook salmon, it was difficult to determine a consistent pattern of the location of mortality, except that in late May 1992 high mortality occurred both in the Chandler Canal and through the Chandler facility. While Chandler Canal 
Table 13. Adjusted Chandler facility to outfall survival estimates for yearling chinook salmon releases where significant mortality was detected due to the facility sampling process in 1991 and 1992 (see Table 8).

\begin{tabular}{|c|c|c|c|c|}
\hline $\begin{array}{l}\text { Release } \\
\text { Date } \\
\end{array}$ & $\begin{array}{l}\text { Sampled } \\
\text { fish } \\
\text { relative } \\
\text { survival }\end{array}$ & $\begin{array}{l}\text { Chandler } \\
\text { facility } \\
\text { sample } \\
\text { proportion }\end{array}$ & $\begin{array}{l}\text { Maximum } \\
\text { likelihood } \\
\text { estimated } \\
\text { Chandler } \\
\text { facility } \\
\text { survival } \\
\end{array}$ & $\begin{array}{l}\text { Adjusted } \\
\text { unsampled } \\
\text { Chandler } \\
\text { facility } \\
\text { survival } \\
\end{array}$ \\
\hline 14 April 1991 & 0.901 & 0.241 & 0.800 & 0.819 \\
\hline 15 April 1991 & 0.731 & 0.177 & 0.887 & 0.931 \\
\hline 16 April 1991 & 0.989 & 0.232 & 0.931 & 0.933 \\
\hline 17 April 1991 & 0.846 & 0.395 & 0.841 & 0.896 \\
\hline 22 April 1991 & 0.870 & 0.341 & 1.203 & 1.259 \\
\hline \multicolumn{5}{|l|}{23 April $1991^{2}$} \\
\hline 24 April 1991 & 0.874 & 0.376 & 1.061 & 1.114 \\
\hline 25 April 1991 & 0.983 & 0.637 & 0.933 & 0.943 \\
\hline 26 April 1991 & 1.020 & 0.671 & 0.985 & 0.972 \\
\hline 1 May 1991 & 0.982 & 0.509 & 1.054 & 1.064 \\
\hline 2 May 1991 & 0.884 & 0.416 & 0.787 & 0.827 \\
\hline 3 May 1991 & 0.884 & 0.390 & 0.828 & 0.867 \\
\hline 4 May 1991 & 0.953 & 0.296 & 0.871 & 0.883 \\
\hline 5 May 1991 & 1.044 & 0.119 & 0.798 & 0.794 \\
\hline \multicolumn{5}{|l|}{7 May $1991^{b}$} \\
\hline Mean & 0.920 & 0.369 & 0.921 & 0.946 \\
\hline $\mathbf{S E}^{\mathrm{c}}$ & 0.024 & 0.046 & 0.035 & 0.036 \\
\hline 14 April 1992 & 0.881 & 0.319 & 0.790 & 0.821 \\
\hline 16 April 1992 & 0.727 & 0.297 & 1.137 & 1.237 \\
\hline 18 April 1992 & 0.891 & 0.263 & 0.926 & 0.953 \\
\hline 20 April 1992 & 0.643 & 0.244 & 1.075 & 1.177 \\
\hline 21 April 1992 & 0.722 & 0.358 & 0.821 & 0.912 \\
\hline 22 April 1992 & 0.732 & 0.322 & 0.897 & 0.982 \\
\hline Mean & 0.766 & 0.301 & 0.941 & 1.014 \\
\hline SE & 0.040 & 0.017 & 0.056 & 0.066 \\
\hline
\end{tabular}

No estimates calculated due to poor mixing at McNary Dam.

b No estimates calculated due to Chandler facility PIT-tag detector malfunction.

- $\mathrm{SE}=$ Standard Error of the Mean. 
survival was assumed to be related to river conditions, low survival through the Chandler facility may have resulted from a combination of the sampling process, river conditions, and avian predation at the facility outfall.

\section{Comparison with River Conditions}

Since nearly all survival estimates (S1-S4) were high and averaged close to $100 \%$ (except for yearling chinook salmon $S 2$ estimates), no attempt was made to correlate survival in the corresponding reaches with river conditions such as water temperature or flow volume (Appendix Table 10). It was apparent over the range of conditions tested that survival was not affected by any environmental factors.

However, the precipitous decline in S2 yearling chinook salmon survival estimates after 12 May 1992 suggested that survival between the Chandler Canal and the facility for that species was linked to some water condition in the canal. Therefore, the relationships between S2 survival estimates and water temperature and volume were examined. Estimates from 1991 and 1992 were combined based on the assumption that any cause-and-effect relationship would be the same in both years.

Lower survival through the Chandler Canal for yearling chinook salmon was clearly associated with later release dates at higher water temperatures and lower flow volumes (Figs. 3-5). However, the paucity of data falling in the middle of distributions for release date, water temperature, and canal water-flow distributions made it difficult to determine the functional relationship between these variables and canal survival. Threshold- and continuous-type models could not be differentiated using the observed data. Therefore, statistical models were not developed for these relationships. Significant yearling chinook salmon mortality in the Chandler 


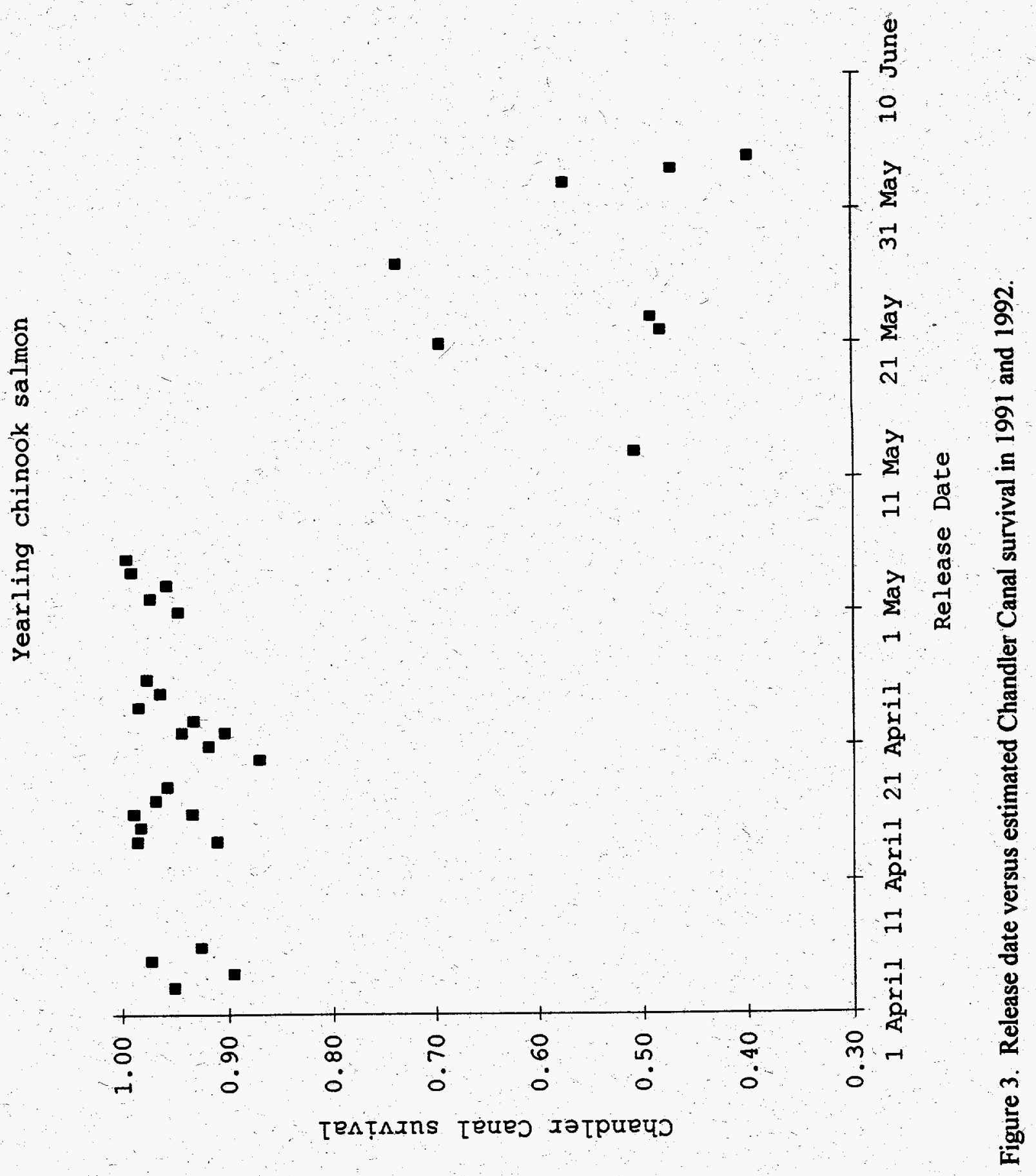




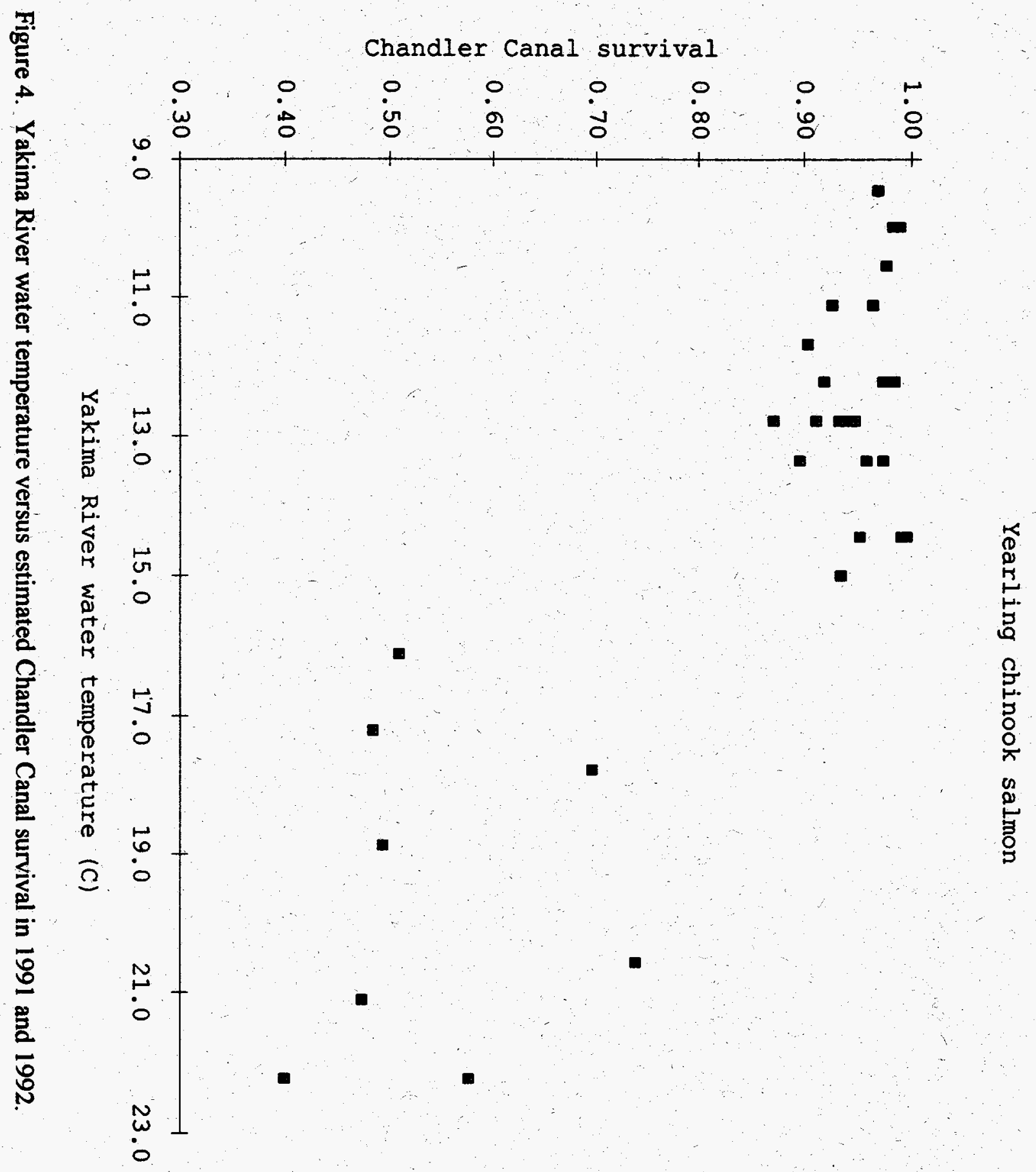




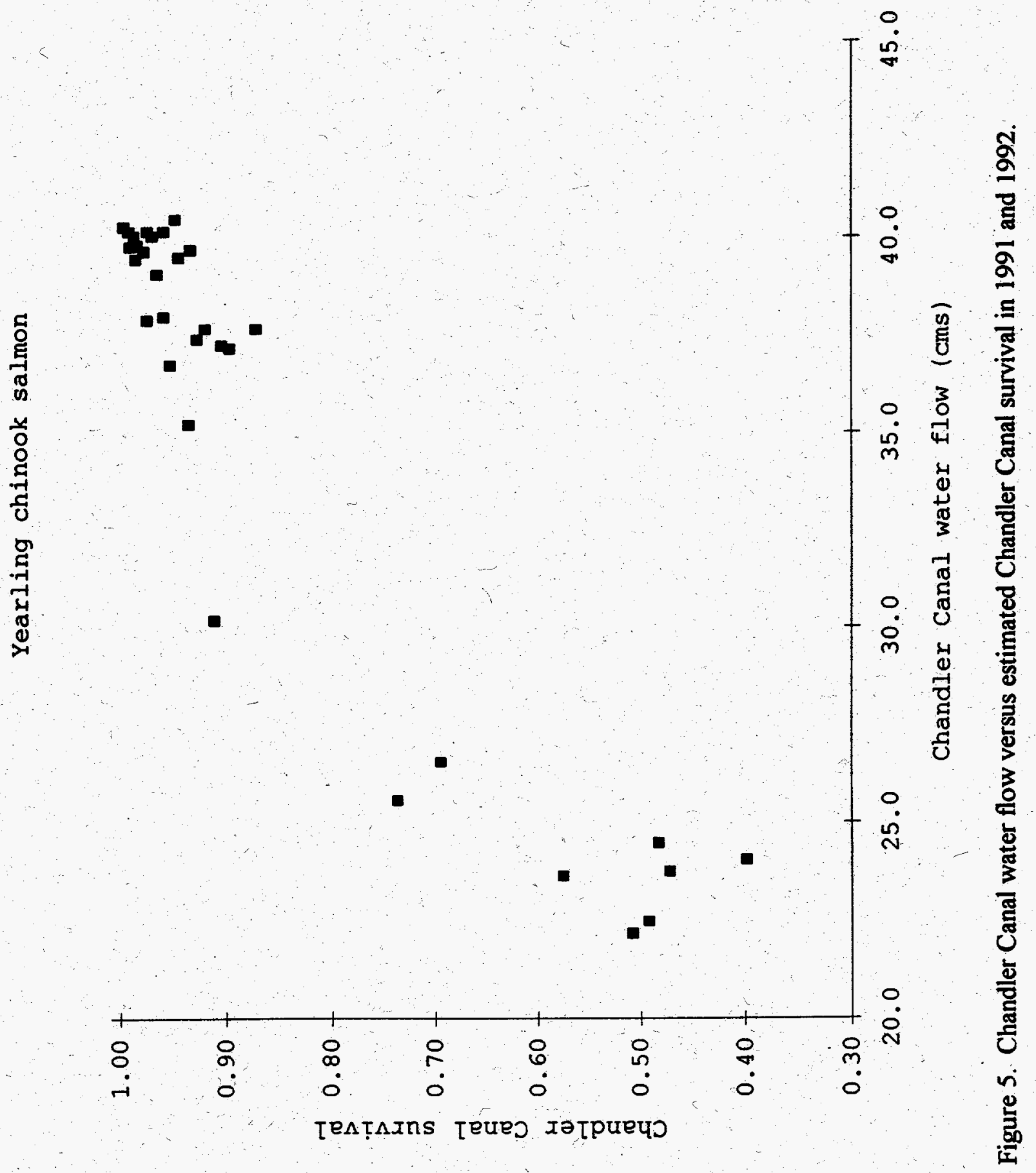


Canal to the facility occurred after 12 May when water temperatures exceeded $15^{\circ} \mathrm{C}\left(59^{\circ} \mathrm{F}\right)$ and canal water flow was less than $30.0 \mathrm{cms}(1060 \mathrm{cfs})$.

Survival estimates through the Chandler facility for yearling chinook salmon were also substantially lower after 12 May 1992 and were associated with high water temperatures and low water flows in the Yakima River (Figs. 6-8). (The discussion in the preceding paragraph regarding the choice of appropriate statistical models also applied to the observed relationships between release date, river water temperature, and survival through the Chandler facility).

Survival appeared random and quite variable over release dates and water temperatures of $9-16^{\circ} \mathrm{C}$ $\left(48-61^{\circ} \mathrm{F}\right)$ but decreased after 12 May when water temperature was above $17^{\circ} \mathrm{C}\left(63^{\circ} \mathrm{F}\right)$. Survival appeared random and quite variable over the observed flow range of 12.4-105.7 cms (438-3732 cfs) until after 12 May 1992, when it dropped substantially. Yet, it was still within the flow range observed before 12 May.

\section{Chandler Canal Water Flow versus Fish Entrainment}

The proportion of water diverted on test days and the MLEs of the proportion of fish entrained into the Chandler Canal (Tables 11 and 12) are shown in Figures 9 and 10. Individual standard errors based on multinomial sampling error for the MLEs are listed in Appendix Tables 8 and 9. For yearling chinook salmon, the best-fitting regression curve was estimated as:

$$
\mathrm{Fi}=1.368-0.234 / \mathrm{Fl}
$$

with a $95 \%$ prediction interval of: 


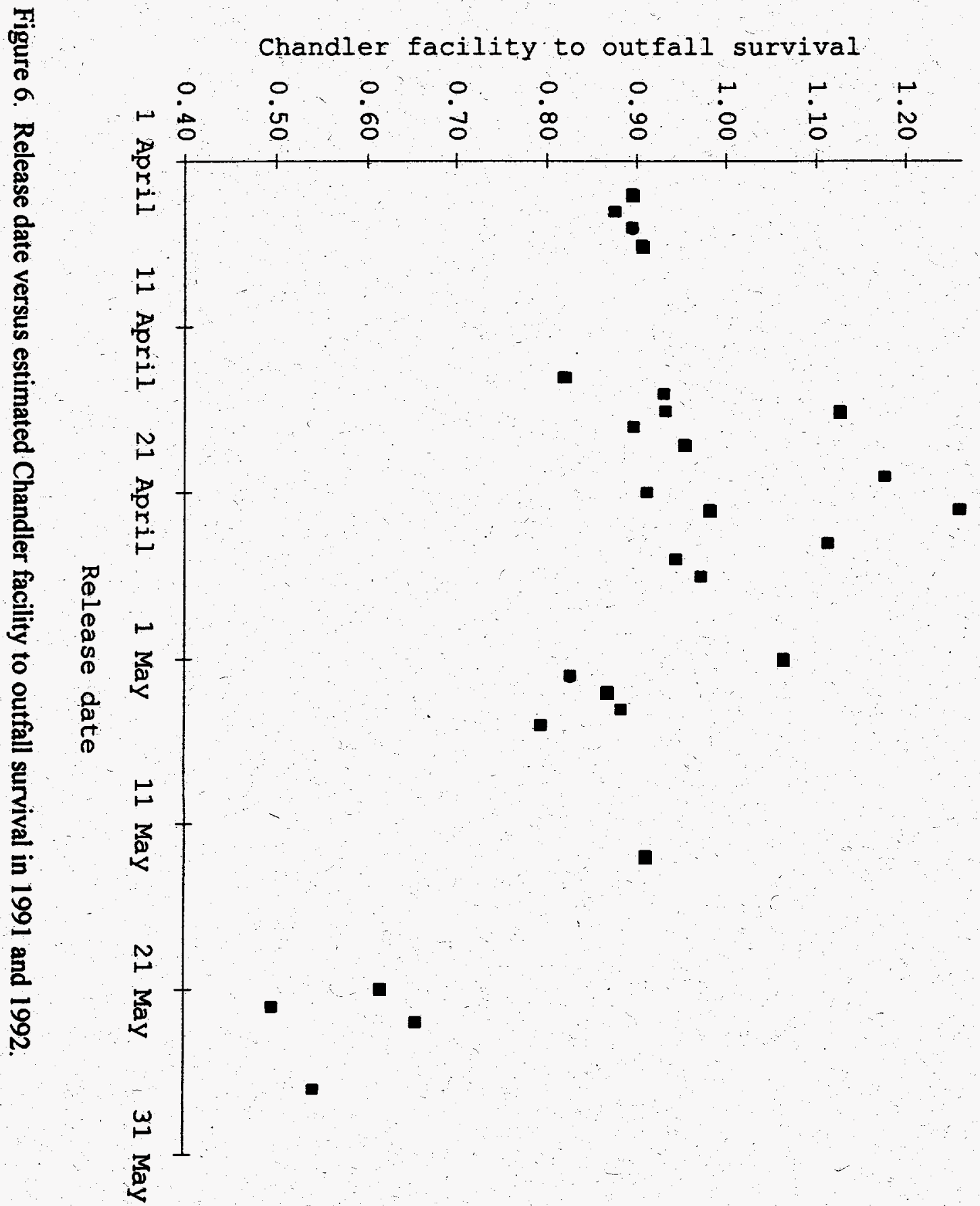

0
0
0
5
5
0
0
8
8
5
8
0
0
0
0
5
0
0 


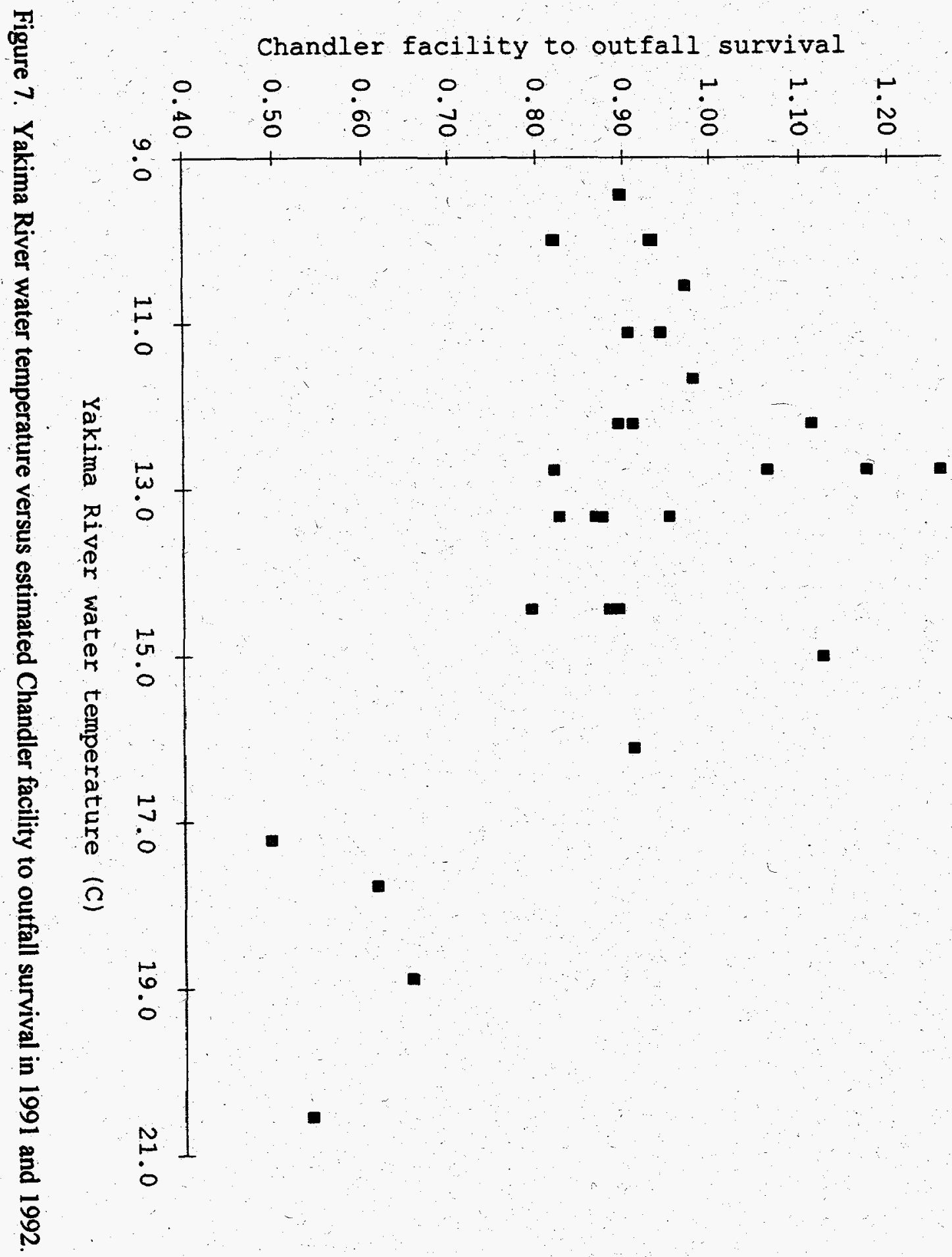

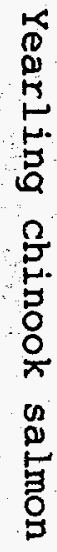




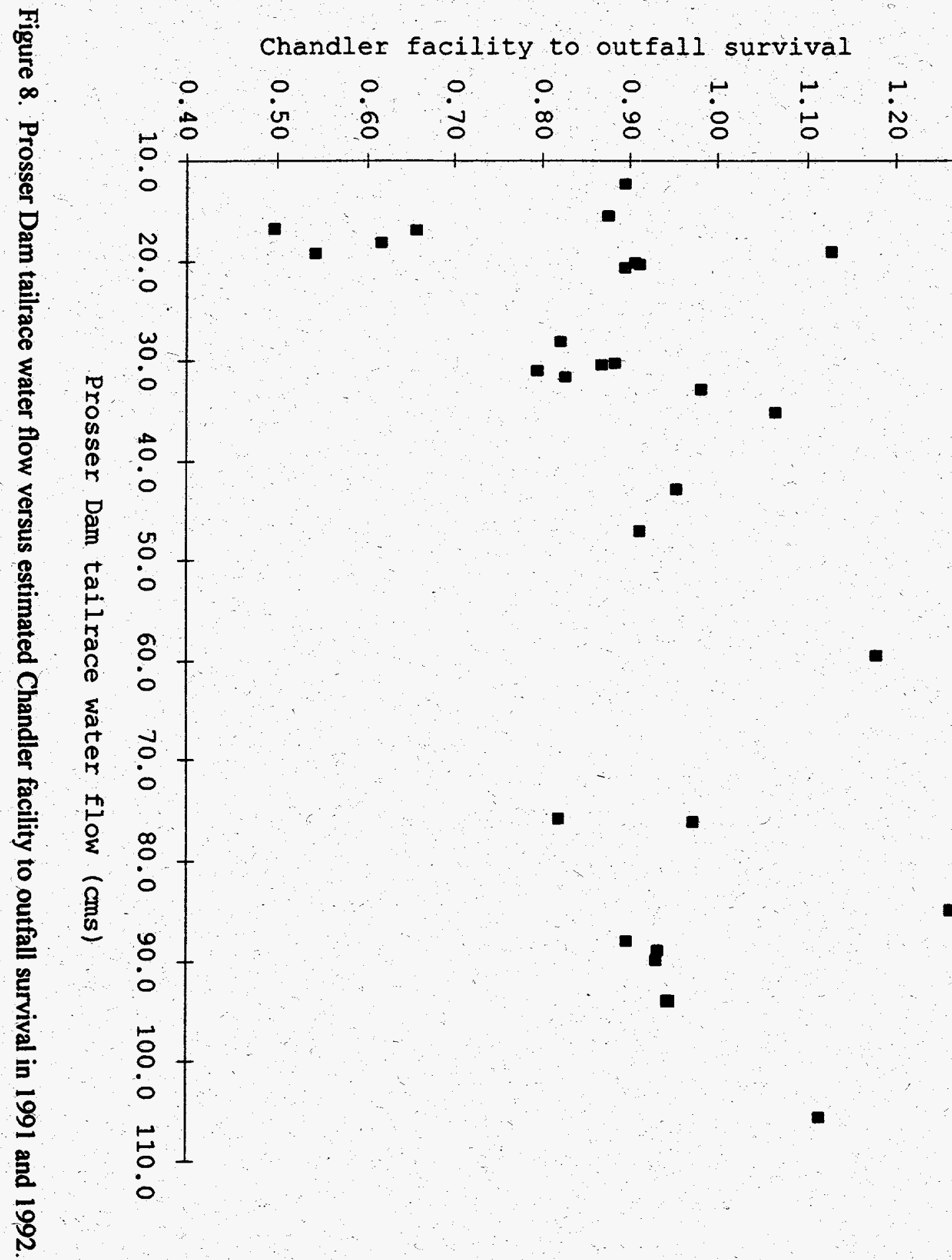

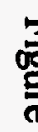


率

Estimated proportion of fish entrained in Chandler Canal

实 要

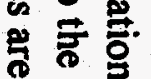

设

를

응 $\$$

을 를

홍ํㅇㅇํㅇ

을

20

용.

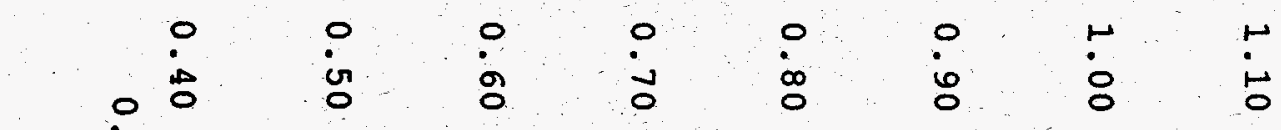

훙

\&

을

훙

就安

둥

$\stackrel{9}{\$}$

롱

正

2

丞

量

参.

ㅎํำ

웅 올

흘.

음

ริ

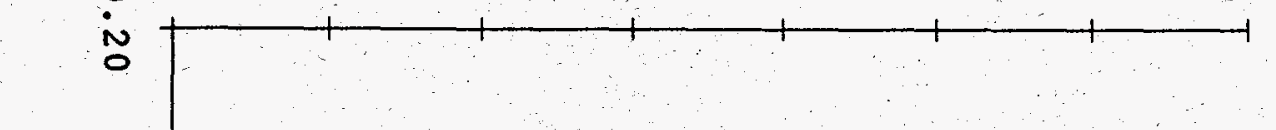

荢

हे

을

营

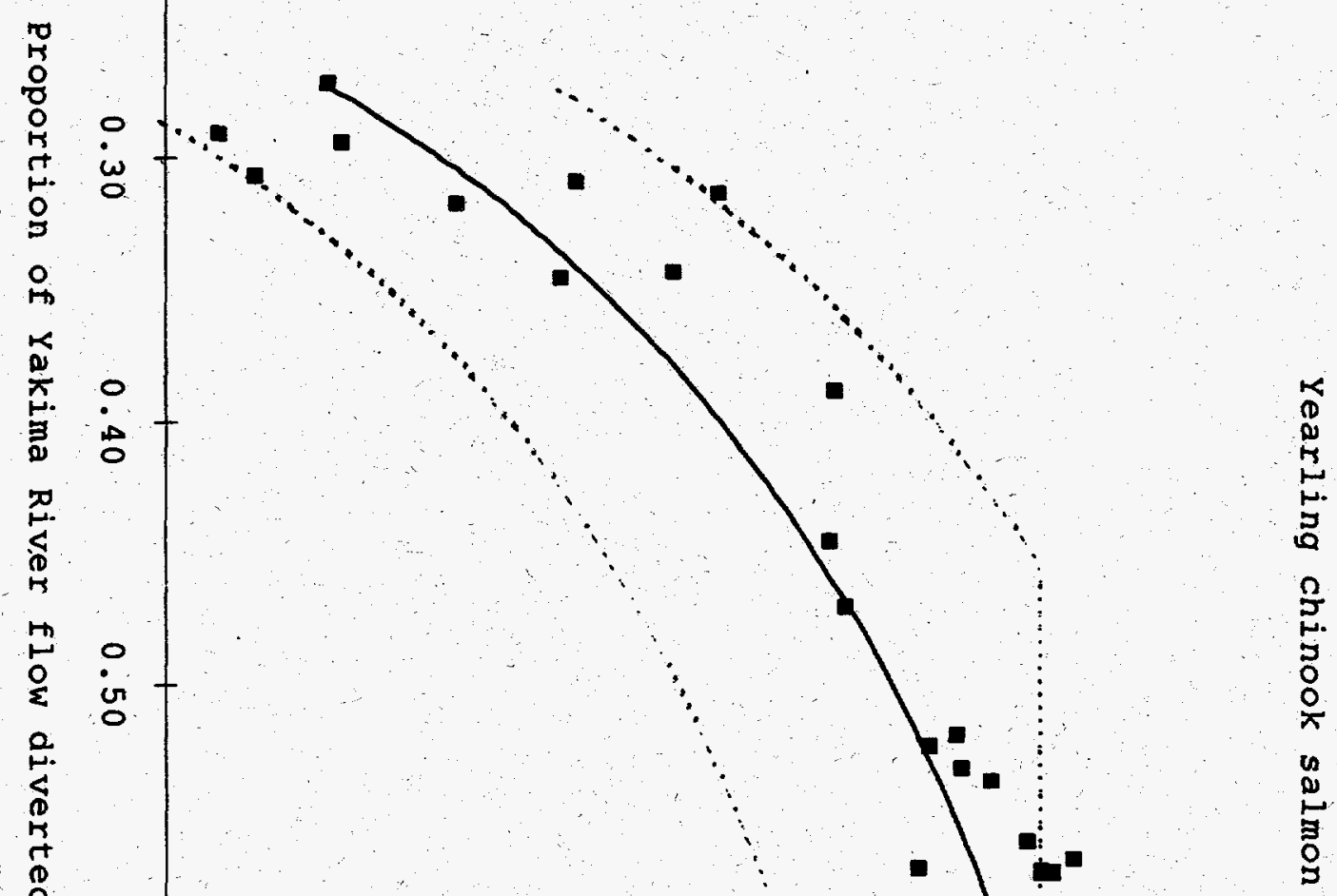


$\frac{7}{0}$

Estimated proportion of fish entrained in Chandler Canal

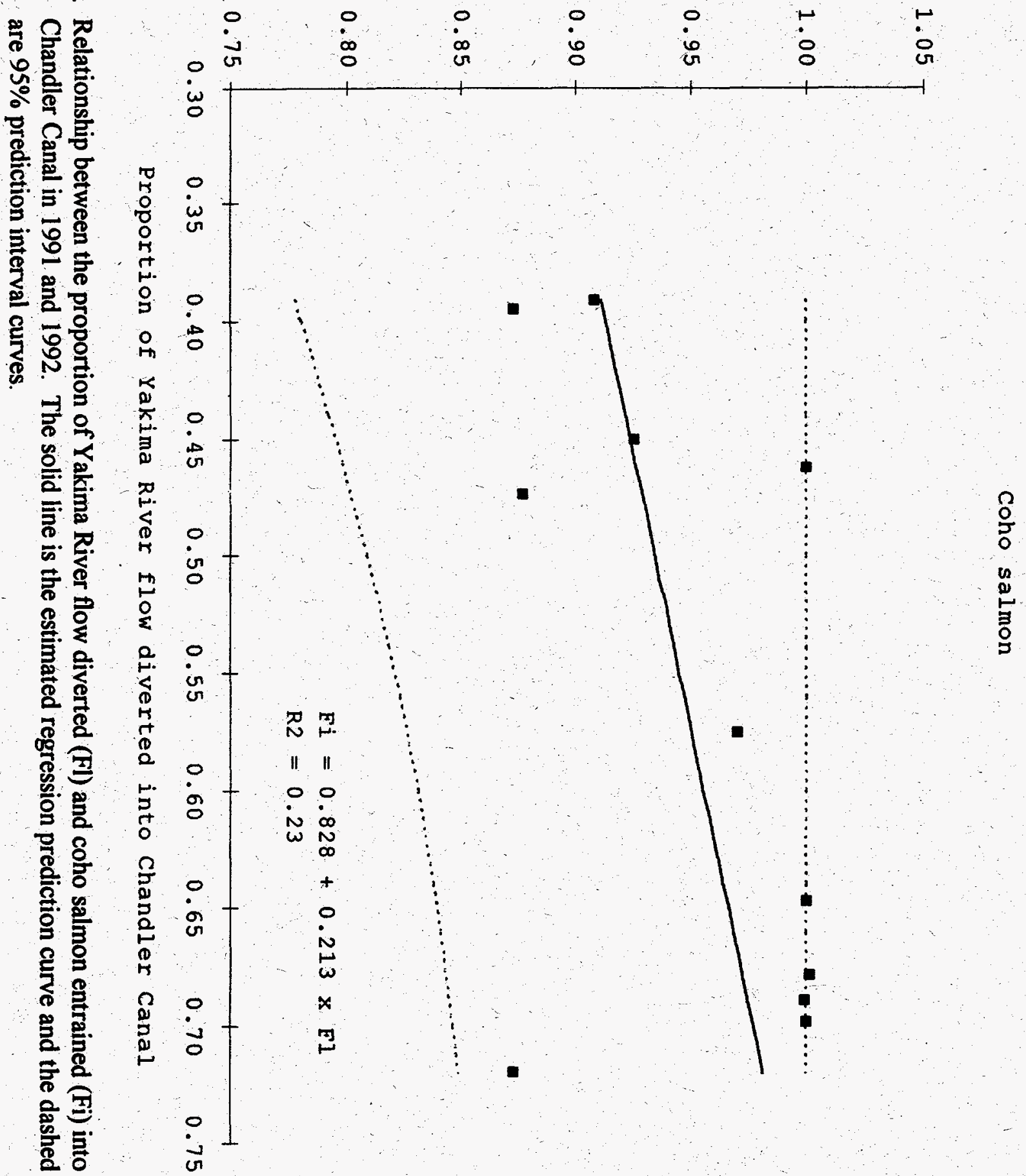

实 $\overrightarrow{\bar{\sigma}}$ 


$$
\mathrm{Fi} \pm 0.1443\left[1.0345+\frac{\left(\frac{1}{F}-2.2447\right)^{2}}{15.0275}\right]^{\frac{1}{2}}
$$

where Fi is the predicted proportion of fish entrained in Chandler Canal and Fl is the proportion of flow diverted into the canal. This regression model accounted for $86 \%$ of variation in the proportion of fish entrained in the canal (i.e., $R^{2}=0.86$ ). The model residuals, predicted minus actual values, appeared fairly random around zero and normally distributed. However, some "lack-of-fit" of the curve was apparent from visual inspection of the data shown in Fig. 9 (i.e., the curve didn't seem to bend quite as sharply as the data scatterplot suggested). This primarily resulted from having many more flow proportion diverted values on the ends of the range (around 0.3 and $0.5-0.7)$ than in the middle $(0.35-0.5)$. That is, these middle values were less able to "shape" the curve in their neighborhood.

For coho salmon, the best-fitting curve was estimated as:

$$
\mathrm{Fi}=0.828+0.213 \times \mathrm{Fl}
$$

with a $95 \%$ prediction interval of:

$$
\mathrm{Fi} \pm 0.1189\left[1.0909+\frac{(\mathrm{F} \mathrm{I}-0.5616)^{2}}{0.1680}\right]^{\frac{1}{2}}
$$

This regression model accounted for only $23 \%$ of the variation in the proportion of fish entrained in the canal (i.e., $\mathbf{R}^{2}=0.23$ ). Curve estimation and regression diagnostics (e.g., residual plots) were difficult to interpret from this small data set $(n=11)$. For example, the largest value for the 
proportion of flow diverted was associated with nearly the lowest value for the proportion of fish entrained, and this value also had the largest regression-model residual. This data point had strong influence on how the flow-diversion/fish-entrainment relationship was determined both from the standpoint of fitting a regression model and from visual inspection of the data scatterplot. Removal of this value from the regression considerably changed the prediction equation to $\mathrm{Fi}=0.766+0.345 \times \mathrm{Fl}$ and increased $\mathrm{R}^{2}$ to 0.64 .

The above prediction curves can be used to expand future fish counts at the Chandier facility into Prosser Dam passage numbers (for tagged and untagged fish). However, several caveats should be noted:

1. The precision of such estimates, as calculated from the prediction intervals above, will be fairly low. For yearling chinook and coho salmon, predicted fish entrainment estimates could vary by a minimum of 14.7 and $12.4 \%$, respectively (e.g.; given a percentage of flow diverted of $45 \%$, a researcher would predict that $85 \%$ of yearling chinook salmon would be entrained but could only say with $95 \%$ confidence that the true percentage of fish entrained was between 70.3 and $99.7 \%)$.

2. These prediction curves should only be used for flow entrainment proportions observed in this study. Flow proportions greater than those observed most likely imply $100 \%$ fish entrainment, but the relationship for flow proportions less than those observed is unknown. If data were available over the entire range of possible flow diversion proportions, it is possible that a different predictor function would be appropriate. 
3. Expansion estimates using these curves need to be adjusted for Chandler Canal to facility estimated survival and facility main PIT-tag detector efficiency. Estimates at "low" canal flow volumes would be highly variable.

4. The accuracy of the coho salmon prediction curve is somewhat tenuous due to small sample size.

\section{Maximum Likelihood vs Expanded Detection Proportion and Relative Recapture}

The mean ratio of MLE to EDP estimates of Chandler Canal survival over years and species was $0.996(\mathrm{SE}=0.003$; Table 14). Individual values ranged from 0.966 to 1.033 . Therefore, the average estimates from the two methods were not significantly different. Furthermore, individual estimates were not highly variable. The EDP method can be used to obtain Chandler Canal survival estimates in the future as long as the Chandler facility main PITtag detector efficiency can be estimated.

The mean ratio of the MLE to RR estimates of the proportion of fish entrained into Chandler Canal over years and species was $1.003(\mathrm{SE}=0.008$, Table 14). Individual values ranged from 0.894 to 1.154 . Therefore, average estimates from the two methods were not significantly different. Furthermore, individual estimates were not highly variable. The RR method can be used to obtain entrainment estimates in the future as long as $100 \%$ survival from the $\mathrm{R} 1$ release point to the Chandler Canal can be assumed.

\section{Chandler Facility Main PIT-tag Detector Efficiency}

MLEs of the PIT-tag detection efficiency of the Chandler facility exceeded $94 \%$ for all release days over both years and species, with means and standard errors ranging from 97.4 to 
Table 14. Comparison of the 1991 and 1992 expanded detection proportion (EDP) Chandler Canal survival estimates and the relative recapture (RR) Chandler Canal fish entrainment proportion estimates with the maximum likelihood (MLE) estimates.

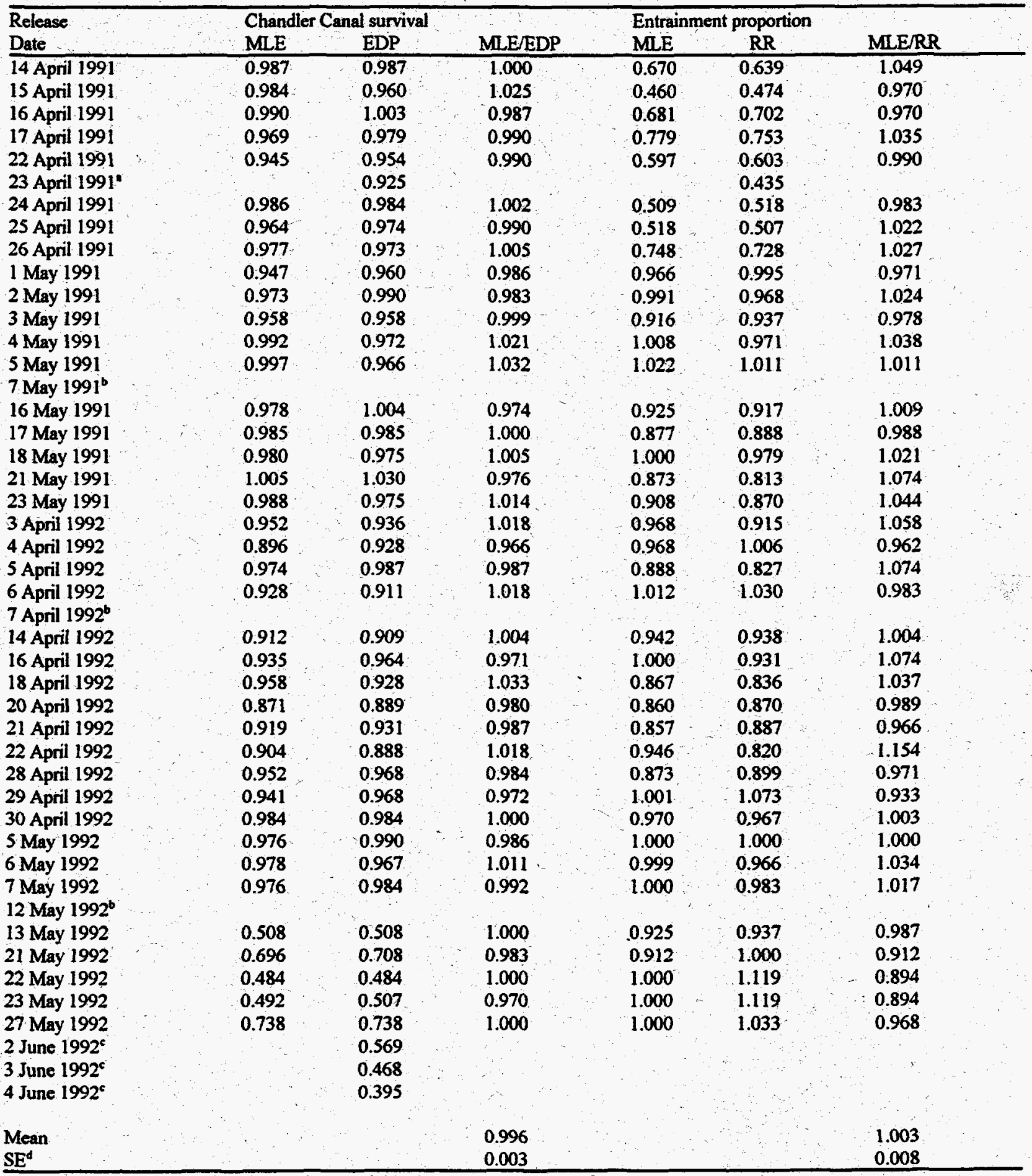

- No MLE estimates calculated due to poor mixing at McNary Dam

b No estimates calculated due to Chandler facility PIT-tag detector malfunction.

c No MLE or RR estimates calculated due to very small sample sizes or no assumption of $100 \%$ Prosser Dam forebay survival.

d $\mathrm{SE}=$ Standard Error of the Mean. 
$97.9 \%$ and 0.4 to $0.6 \%$, respectively (Tables 11 and 12). Model-based individual standard errors are listed in Appendix Tables 8 and 9. However, in 22 of the 39 tests, the efficiency was not estimable by the full likelihood model and was assumed to be $100 \%$ due to 0 detections at McNary Dam of fish not previously detected at the Chandler facility.

Estimates of the Chandler facility main PIT-tag detector efficiency based on sample PITtag detector detections of $\mathrm{R} 1$ and $\mathrm{R} 2$ releases exceeded $95 \%$ for all release days over both years and species with means and standard errors ranging from 98.0 to $99.0 \%$ and 0.2 to $0.9 \%$, respectively (Table 15). Estimates were obtained by this approach for all release days, with sample sizes in excess of 30 sample detections, except in June 1992. Sample sizes for the June 1992 releases ranged from 8 to 19 , with detector efficiency estimates at $100 \%$.

\section{Travel Time}

\section{Chandler Facility}

In 1991, the fastest travel times to the Chandler facility for fish released in the Chandler Canal averaged $0.7(\mathrm{SE}=0.1)$ and 0.5 hours $(\mathrm{SE}=0.1)$ for yearling chinook and coho salmon, respectively (Table 16). For both species, this was an average of about 0.8 hours $(S E=0.1)$ faster than the minimum travel time for fish released in the Prosser Dam forebay. In 1992, the fastest travel times to the Chandler facility for fish released in the Chandler Canal averaged 1.7 $(\mathrm{SE}=0.2)$ and 1.8 hours $(\mathrm{SE}=0.1)$ for yearling chinook and coho salmon, respectively (Table 17). This averaged $1.1(\mathrm{SE}=0.1)$ and 0.6 hours $(\mathrm{SE}=0.1)$ faster than the minimum travel time for forebay-released yearling chinook and coho salmon, respectively. Within both years, minimum travel times of individual release days were fairly consistent. 
Table 15. Estimated Chandler facility main PIT-tag detector (MD) efficiency based on sample PIT-tag detector (SD) detections of Prosser Dam forebay and Chandler Canal yearling chinook and coho salmon releases in 1991 and 1992.

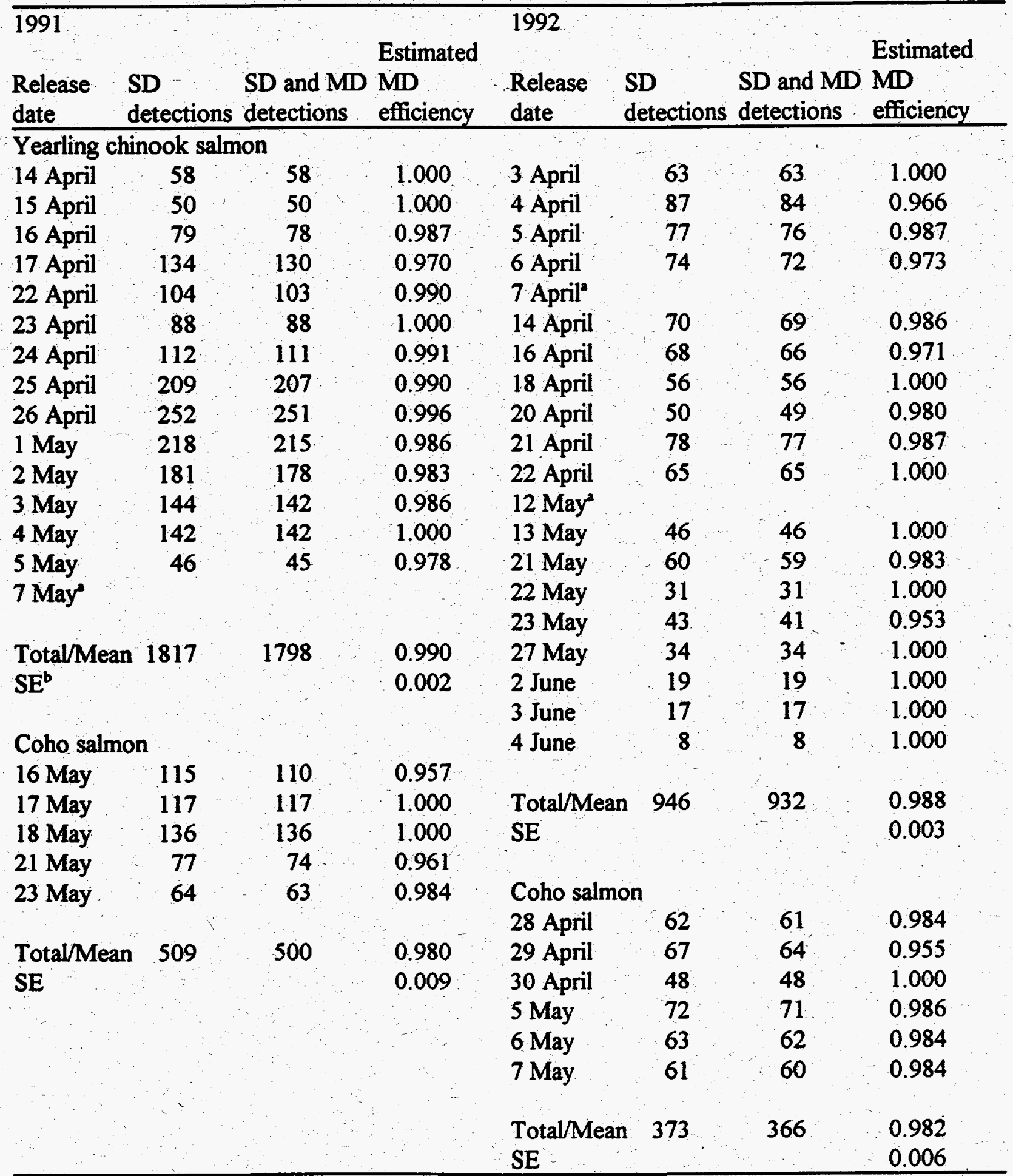

No estimates made due to Chandler facility PIT-tag detector malfunction.

b $\mathrm{SE}=$ Standard Error of the Mean. 
Table 16. Minimum and median travel time (TT) to the Chandler facility for yearling chinook and coho salmon released $1 \mathrm{~km}$ above Prosser Dam (Forebay) or at the headworks of the Chandler Canal (Canal) in 1991.

\begin{tabular}{|c|c|c|c|c|c|c|}
\hline $\begin{array}{l}\text { Release } \\
\text { date }\end{array}$ & $\begin{array}{l}\text { Forebay } \\
\text { Minimum } \\
\text { TT (hours) }\end{array}$ & $\begin{array}{l}\text { Canal } \\
\text { Minimum } \\
\text { TT (hours) }\end{array}$ & $\begin{array}{l}\text { Forebay } \\
\text { - Canal } \\
\text { (hours) }\end{array}$ & $\begin{array}{l}\text { Forebay } \\
\text { Median } \\
\text { TT (hours) }\end{array}$ & $\begin{array}{l}\text { Canal } \\
\text { Median } \\
\text { TT (hours) }\end{array}$ & $\begin{array}{l}\text { Forebay } \\
\text { - Canal } \\
\text { (hours) }\end{array}$ \\
\hline \multicolumn{7}{|c|}{ Yearling chinook salmon } \\
\hline 14 April & 0.2 & 0.6 & -0.4 & 2.7 & 2.1 & 0.7 \\
\hline 15 April & 1.3 & 0.5 & 0.8 & 2.7 & 2.0 & 0.7 \\
\hline 16 April & 1.5 & 0.6 & 1.0 & 3.2 & 2.3 & 0.9 \\
\hline 17 April & 2.3 & 1.2 & $1: 1$ & 4.1 & 3.8 & 0.4 \\
\hline 22 April & 2.4 & 1.1 & 1.4 & 3.5 & 3.5 & -0.1 \\
\hline 23 April & 1.2 & 0.8 & 0.5 & 3.1 & 3.2 & 0.0 \\
\hline 24 April & 1.4 & 0.8 & 0.6 & 2.7 & 2.0 & 0.7 \\
\hline 25 April & 1.2 & 0.9 & 0.3 & 3.3 & 2.8 & 0.5 \\
\hline 26 April & 1.3 & 0.6 & 0.7 & 3.4 & 2.1 & 1.3 \\
\hline 1 May & 2.0 & 0.7 & 1.3 & 6.1 & 5.3 & 0.8 \\
\hline 2 May & 1.7 & 0.8 & 0.8 & 4.6 & 3.9 & 0.7 \\
\hline 3 May & 1.5 & 0.6 & 0.9 & 5.5 & 5.5 & 0.1 \\
\hline 4May & 1.1 & 0.7 & 0.4 & 4.5 & 2.0 & 2.5 \\
\hline 5 May & 1.3 & 0.7 & 0.6 & 4.2 & 2.0 & 2.3 \\
\hline \multicolumn{7}{|l|}{ 7. May" } \\
\hline Mean & 1.5 & 0.7 & 0.7 & 3.8 & 3.0 & 0.8 \\
\hline $\mathbf{S E}^{\mathbf{b}}$ & 0.1 & 0.1 & 0.1 & 0.3 & 0.3 & 0.2 \\
\hline \multicolumn{7}{|c|}{ Coho salmon } \\
\hline 16 May & 1.2 & 0.5 & 0.7 & 2.6 & 2.0 & 0.5 \\
\hline 17 May & 1.6 & 0.3 & 1.3 & 3.1 & 2.3 & 0.8 \\
\hline 18 May & 1.2 & 0.4 & 0.8 & 2.6 & 2.2 & 0.5 \\
\hline 21 May & 1.1 & 0.7 & 0.5 & 2.3 . & 1.8 & 0.6 \\
\hline 23 May & 1.3 & 0.4 & 0.9 & 2.1 & 1.5 & 0.6 \\
\hline Mean & 1.3 & 0.5 & 0.8 & 2.6 & 2.0 & 0.6 \\
\hline SE & 0.1 & 0.1 & 0.1 & 0.2 & 0.1 & 0.1 \\
\hline
\end{tabular}

a No estimates calculated due to Chandler facility PIT-tag detector malfunction.

b $\mathrm{SE}=$ Standard Error of the Mean. 
Table 17. Minimum and median travel time (TT) to the Chandler facility for yearling chinook and coho salmon released $1 \mathrm{~km}$ above Prosser Dam (Forebay) or at the headworks of the Chandler Canal (Canal) in 1992.

\begin{tabular}{|c|c|c|c|c|c|c|}
\hline $\begin{array}{l}\text { Release } \\
\text { date }\end{array}$ & $\begin{array}{l}\text { Forebay } \\
\text { Minimum } \\
\text { TT (hours) }\end{array}$ & $\begin{array}{l}\text { Canal } \\
\text { Minimum } \\
\text { TT (hours) }\end{array}$ & $\begin{array}{l}\text { Forebay } \\
\text { - Canal } \\
\text { (hours) }\end{array}$ & $\begin{array}{l}\text { Forebay } \\
\text { Median } \\
\text { TT (hours) }\end{array}$ & $\begin{array}{l}\text { Canal } \\
\text { Median } \\
\text { TT (hours) }\end{array}$ & $\begin{array}{l}\text { Forebay } \\
\text { - Canal } \\
\text { (hours) }\end{array}$ \\
\hline \multicolumn{7}{|c|}{ Yearling chinook salmon } \\
\hline 3 April & 2.1 & 1.0 & 1.0 & 13.5 & 13.6 & -0.2 \\
\hline 4 April & 2.3 & 1.0 & 1.3 & 14.3 & 14.3 & 0.0 \\
\hline 5 April & 1.7 & 1.0 & 0.6 & 11.2 & 15.2 & -4.1 \\
\hline 6 April & 1.9 & 1.1 & 0.9 & 14.9 & 14.8 & 0.1 \\
\hline \multicolumn{7}{|l|}{7 April $^{2}$} \\
\hline 14 April & 3.4 & 1.7 & 1.6 & 39.7 & 37.3 & 2.3 \\
\hline 16 April & 2.6 & 1.5 & 1.1 & 10.8 & 8.8 & 1.9 \\
\hline 18 April & 2.4 & 1.5 & 0.9 & 4.3 & 3.4 & 0.9 \\
\hline 20 April & 2.5 & 1.5 & 1.0 & 4.6 & 4.3 & 0.3 \\
\hline 21 April & 2.3 & 2.0 & 0.3 & 5.0 & 5.2 & -0.1 \\
\hline \multicolumn{7}{|l|}{$12 \mathrm{May}^{3}$} \\
\hline 13 May & 6.0 & 4.1 & 1.9 & 7.4 & 7.8 & -0.4 \\
\hline 21 May & 4.2 & 1.5 & 2.6 & 6.7 & 4.8 & 1.9 \\
\hline 22 May & 3.2 & 2.8 & 0.4 & 9.5 & 9.1 & 0.4 \\
\hline 23 May & 3.1 & 1.6 & 1.5 & 13.9 & 68.3 & -54.4 \\
\hline 27 May & 2.3 & 1.2 & 1.1 & 5.8 & $6: 4$ & -0.5 \\
\hline 2 June & 3.7 & 2.5 & 1.2 & 7.5 & 8.9 & -1.4 \\
\hline 3 June & 2.1 & 1.3 & 0.8 & 6.4 & 7.3 & -1.0 \\
\hline 4 June & 2.4 & 1.9 & 0.5 & 4.7 & 5.3 & -0.5 \\
\hline Mean & 2.8 & 1.7 & 1.1 & 9.5 & 8.1 & -0.1 \\
\hline $\mathbf{S E}^{\mathbf{b}}$ & 0.2 & 0.2 & 0.1 & 2.0 & 1.9 & 0.4 \\
\hline \multicolumn{7}{|c|}{ Coho salmon } \\
\hline 28 April & 2.5 & 1.6 & 0.8 & 4.1 & 3.8 & 0.2 \\
\hline 29 April & 2.6 & 1.7 & 1.0 & 6.0 & 5.5 & 0.5 \\
\hline 30 April & 2.3 & 1.8 & 0.4 & 3.6 & 3.5 & 0.0 \\
\hline 5 May & 2.4 & 1.9 & 0.5 & 3.9 & 3.3 & 0.6 \\
\hline 6 May & 2.4 & 1.9 & 0.5 & 3.8 & 3.3 & 0.5 \\
\hline 7 May & 2.3 & 1.8 & 0.4 & 3.9 & 3.6 & 0.4 \\
\hline Mean & 2.4 & 1.8 & 0.6 & 4.2 & 3.9 & 0.4 \\
\hline SE & 0.1 & 0.1 & 0.1 & 0.4 & 0.3 & 0.1 \\
\hline
\end{tabular}

No estimates calculated due to Chandler facility PIT-tag detector malfunction.

b $\mathrm{SE}=$ Standard Error of the Mean. 
In 1991, the median Chandler Canal-released yearling chinook and coho salmon reached the Chandler facility main PIT-tag detector with means of $3.0(\mathrm{SE}=0.3)$ and 2.0 hours $(\mathrm{SE}=$ $0.1)$, respectively. This was a mean of $0.8(\mathrm{SE}=0.2)$ and 0.6 hours $(\mathrm{SE}=0.1)$ faster than the median Prosser Dam forebay-released fish (Table 16). Median travel time for Chandler Canalreleased coho salmon in 1992 averaged 3.9 hours $(\mathrm{SE}=0.3)$ which was 0.4 hours $(\mathrm{SE}=0.1)$ faster than Prosser Dam forebay-released fish (Table 17). Median travel time characteristics for 1992 yearling chinook salmon were more complex. Between R1 and R2 releases, the median travel time was nearly the same to get to the Chandler facility (the median travel time difference averaged 0.4 hours $(\mathrm{SE}=0.4)$ ). However, average travel times changed over the migration season, as early in April both groups took 11-15 hours, but from mid-April through early June both groups mostly took 3-10 hours. Also, on two occasions median travel times were unexplainably much longer than usual, at nearly 40 hours for both 14 April groups and at 14 and 68 hours for R1 and R2 groups, respectively, on 23 May. Close examination of the PIT-tag observation data for these groups did not adequately reveal any data errors (such as the PIT-tag detector problems described in Appendix 2).

The time between minimum and median detection at the Chandler facility main PIT-tag detector was generally only a few hours. Also, on average, fish released to the Prosser Dam forebay passed the Chandler facility up to an hour or so later than fish released to the Chandler Canal. Therefore, any period of time in the hours following release in which the PIT-tag detector was inoperative or malfunctioned would have affected the $R 1$ and $R 2$ groups differently. This was evidenced for the three release days described in Appendix 2. The observation of significant 
bias in statistical estimates as a result of non-random PIT-tag detection problems underscored the need for highly reliable and stable PIT-tag detection systems and careful documentation of detector problems.

\section{McNary Dam}

In 1991, median travel times from release to primary detection at McNary Dam were fairly similar between releases within days but varied substantially over time and between species (Table 18). Median travel time for yearling chinook salmon in April and May averaged 10.7 (SEs averaged 0.5 days) and 6.2 days (SEs averaged 0.2 days), respectively, while median travel time for coho salmon later in May averaged 3.2 days (SEs all 0.1 days). The maximum difference between groups released on the same day ranged from 0.4 to 2.9 days. Only two median travel time maximum differences were in excess of 2 days: the $R 2$ release group median travel time was over 2 days longer than all groups on 22 April, and both the R1 and $R 2$ group median travel times were over 2 days longer than the R3 group on 23 April.

McNary Dam 1991 passage distributions for yearling chinook salmon were quite protracted in April, encompassing 3 to 4 weeks; they were somewhat shorter in early May at around 2 weeks. Coho salmon passage distributions later in May were quite compact, with most fish passing in 3 to 4 days (Appendix Tables 3a-3d).

Median travel times from release to primary detection at McNary Dam in 1992 were somewhat variable between releases within days and varied considerably over time and between species (Table 19). For yearling chinook salmon in early April, median travel times were fairly consistent and averaged 16.6 days (SEs averaged 0.2 days). Maximum differences between groups released on the same day ranged from 0.8 to 2.0 days, but the groups with the longest and 
Table 18. Median travel time (TT) to McNary Dam in 1991 of yearling chinook and coho salmon released approximately one $\mathrm{km}$ upstream from Prosser Dam (R1), at the headworks of the Chandler Canal (R2), immediately below Prosser Dam (R3), or at the Chandler facility outfall (R4).

\begin{tabular}{|c|c|c|c|c|c|}
\hline $\begin{array}{l}\text { Release } \\
\text { date }\end{array}$ & $\begin{array}{l}\text { R1 } \\
\text { Median } \\
\text { TT (days) }\end{array}$ & $\begin{array}{l}\text { R2 } \\
\text { Median } \\
\text { TT (days) }\end{array}$ & $\begin{array}{l}\text { R3 } \\
\text { Median } \\
\text { TT (days) }\end{array}$ & $\begin{array}{l}\text { R4 } \\
\text { Median } \\
\text { TT (days) }\end{array}$ & $\begin{array}{l}\text { Maximum } \\
\text { Difference } \\
\text { (days) }\end{array}$ \\
\hline \multicolumn{6}{|c|}{ Yearling chinook salmon } \\
\hline 14 April & 11.8 & 12.9 & 11.8 & 12.9 & 1.1 \\
\hline 15 April & 10.2 & 11.0 & 11.9 & 10.9 & 1.7 \\
\hline 16 April & 11.2 & 11.9 & 10.9 & 11.8 & 1.0 \\
\hline 17 April & 10.7 & 11.3 & 10.5 & 11.3 & 0.8 \\
\hline 22 April & 6.9 & 9.7 & 7.3 & 6.8 & 2.9 \\
\hline 23 April & 9.8 & 10.3 & 7.5 & 8.8 & 2.8 \\
\hline 24 April & 10.9 & 10.7 & 10.4 & 11.4 & 1.0 \\
\hline 25 April & 11.7 & 11.7 & 10.0 & 11.2 & 1.7 \\
\hline 26 April & 11.0 & 11.8 & 10.9 & 11.8 & 0.9 \\
\hline Mean & 10.5 & 11.2 & 10.1 & 10.8 & 1.5 \\
\hline$S E^{a}$ & 0.5 & 0.3 & 0.6 & 0.6 & 0.3 \\
\hline 1 May & 7.4 & 7.2 & 6.8 & 6.8 & 0.6 \\
\hline 2 May & 6.8 & 6.9 & 6.8 & 6.1 & 0.8 \\
\hline 3 May & 6.3 & 6.1 & 5.9 & 5.4 & 0.9 \\
\hline 4 May & 6.0 & 5.9 & 5.8 & 5.6 & 0.4 \\
\hline 5 May & 6.6 & 6.0 & 5.4 & 5.0 & 1.6 \\
\hline 7 May & 5.8 & 6.6 & 5.4 & 6.0 & 1.2 \\
\hline Mean & 6.5 & 6.4 & 6.0 & 5.8 & 0.9 \\
\hline $\mathrm{SE}$ & 0.2 & 0.2 & 0.3 & 0.3 & 0.2 \\
\hline \multicolumn{6}{|c|}{ Coho salmon } \\
\hline 16 May & 3.8 & 3.8 & 3.1 & 3.1 & 0.7 \\
\hline 17 May & 3.4 & 3.7 & 3.3 & 3.2 & 0.5 \\
\hline 18 May & 3.3 & 3,4 & 2.6 & 2.7 & 0.8 \\
\hline 21 May & 3.4 & 3.2 & 3.0 & 2.6 & 0.8 \\
\hline 23 May & 3.1 & 3.5 & 2.9 & 2.8 & 0.7 \\
\hline Mean & 3.4 & 3.5 & 3.0 & 2.9 & 0.7 \\
\hline SE & 0.1 & 0.1 & 0.1 & 0.1 & 0.1 \\
\hline
\end{tabular}

SE $=$ Standard Error of the Mean. 
Table 19. Median travel time (TT) to McNary Dam in 1992 of yearling chinook and coho salmon released approximately one $\mathrm{km}$ upstream from Prosser Dam (R1), at the headworks of the Chandler Canal (R2), immediately below Prosser Dam (R3), at the Chandler facility outfall (R4), at the I-82 bridge, or immediately below the main PIT-tag detector in the Chandler facility (R6).

\begin{tabular}{|c|c|c|c|c|c|c|c|}
\hline $\begin{array}{l}\text { Release } \\
\text { date }\end{array}$ & $\begin{array}{l}\text { Rl } \\
\text { Median } \\
\text { TT (days) }\end{array}$ & $\begin{array}{l}\text { R2 } \\
\text { Median } \\
\text { TT (days) }\end{array}$ & $\begin{array}{l}\text { R3 } \\
\text { Median } \\
\text { TT (days) }\end{array}$ & $\begin{array}{l}\text { R4 } \\
\text { Median } \\
\text { TT (days) }\end{array}$ & $\begin{array}{l}\text { R5 } \\
\text { Medain } \\
\text { TT (days) }\end{array}$ & $\begin{array}{l}\text { R6 } \\
\text { Median } \\
\text { TT (days) }\end{array}$ & $\begin{array}{l}\text { Maximum } \\
\text { Difference } \\
\text { (days) }\end{array}$ \\
\hline \multicolumn{8}{|c|}{ Yearling chinook salmon } \\
\hline 3 April & $\therefore 16.6$ & 16.8 & 16.7 & 16.0 & 16.7 & a & 0.8 \\
\hline 4 April & 17.4 & 16.8 & 16.9 & 15.7 & 15.8 & & 1.7 \\
\hline 5 April & 16.4 & 17.7 & 15.7 & 16.0 & 17.0 & & 2.0 \\
\hline 6 April & 16.9 & 15.9 & 16.9 & $17: 0$ & 17.0 & & 1.1 \\
\hline 7.April & 15.9 & 17.8 & 16.9 & 16.7 & 16.8 & & 1.9 \\
\hline Mean & 16.6 & 17.0 & 16.6 & 16.3 & 16.7 & & 1.5 \\
\hline$S^{b}$ & 0.3 & 0.3 & 0.2 & 0.2 & 0.2 & & 0.2 \\
\hline 14 April & 11.7 & 14.0 & 11.2 & 11.7 & 12.0 & & 2.8 \\
\hline 16 April & 11.6 & 12.9 & 9.7 & 11.9 & 10.0 & & 3.2 \\
\hline 18 April & 9.0 & 8.9 & 8.4 & 9.9 & 10.5 & & 2.1 \\
\hline 20 April & 10.2 & 10.7 & 9.9 & 10.4 & 10.6 & 9.8 & 0.9 \\
\hline 21 April & 9.9 & 10.7 & 9.8 & 9.9 & 9.8 & 10.8 & 1.0 \\
\hline 22 April & 9.8 & 9.9 & 9.8 & 9.4 & 9.7 & 9.9 & 0.5 \\
\hline Mean & 10.4 & 11.2 & 9.8 & 10.6 & 10.4 & 10.2 & 1.8 \\
\hline SE & 0.4 & 0.8 & 0.4 & 0.4 & 0.3 & 0.3 & 0.5 \\
\hline 12 May & 31.1 & 32.5 & 20.8 & 28.7 & 30.5 & & 11.7 \\
\hline 13 May & 28.9 & 30.0 & 27.8 & 29.2 & 29.4 & & 2.2 \\
\hline 21 May & 23.7 & 25.1 & 23.8 & 22.5 & 25.5 & & 3.0 \\
\hline 22 May & 27.0 & 21.7 & 24.5 & 23.3 & 22.9 & & 5.1 \\
\hline 23 May & 21.2 & 35.1 . & 21.3 & 22.8 & 24.3 & & 14.1 \\
\hline 27 May & 26.1 & 22.3 & 18.5 & 17.9 & 21.7 & & 8.2 \\
\hline Mean & 26.3 & 27.8 & 22.8 & 24.1 & 25.7 & & 7.4 \\
\hline SE & 1.4 & 2.3 & 1.3 & 1.7 & 1.4 & & 2.0 \\
\hline 28 April & 4.7 & 4.6 & 4.5 & 4.5 & 4.7 & 4.8 & 0.3 \\
\hline 29 April & 5.7 & 5.7 & 4.9 & 4.8 & 5.4 & 5.6 & 0.9 \\
\hline 30 April & 4.8 & 4.8 & 4.6 & 4.6 & 4.6 & 4.7 & 0.2 \\
\hline 5 May & 5.8 & 6.0 & 5.8 & 5.7 & 5.6 & 5.9 & 0.4 \\
\hline 6 May & 5.6 & 5.9 & 5.2 & 5.3 & 5.0 & 5.0 & 0.9 \\
\hline 7 May & 5.6 & 5.8 & 5.4 & 4.9 & 5.0 & 5.1 & 0.9 \\
\hline Mean & 5.3 & 5.5 & 5.1 & 5.0 & 5.0 & 5.2 & 0.6 \\
\hline SE & 0.2 & 0.2 & 0.2 & 0.2 & 0.2 & 0.2 & 0.1 \\
\hline
\end{tabular}

Blanks indicate no releases were made.

b $\mathrm{SE}=$ Standard Error of the Mean. 
shortest median travel times varied daily. Median travel times for the same species in mid-April decreased to an average of 10.4 days (SEs averaged 0.4 days). Maximum differences ranged between 0.5 and 3.2 days, with $R 2$ and $R 3$ groups typically having the longest and shortest median travel times, respectively. Median travel times for the other groups were very similar and generally midway between the $\mathbf{R} 2$ and $\mathbf{R} 3$ groups. In late April to early May, median travel times for coho salmon were very consistent over time and release locations (range of all groups was only 4.5-6.0 days) and averaged 5.2 days (SEs averaged 0.2 days). Maximum differences between median travel times within a release day ranged from 0.2 to 0.9 days. Finally, yearling chinook salmon in May had quite long and highly variable median travel times (range 17.9-35.1 days), averaging 25.3 days (SEs averaged 1.7 days). Maximum differences between same-day release groups ranged from 2.2 to 14.1 days, with the $R 1$ and $R 2$ groups generally having the longest median travel times. The highly variable and lengthy median travel times were the result of small sample sizes and unusual passage distributions at McNary Dam (Appendix Table 3i). There were very few detections recorded for these groups in late May and early June.

McNary Dam 1992 passage distributions for yearling chinook salmon were quite protracted in April, encompassing over 2 to 3 weeks. Coho salmon passage distributions in late April and early May were fairly compact but heavily right-tailed, with most fish passing in 4 to 5 days but with the rest spread over more than an additional week later. The two yearling chinook salmon early May passage distributions were nearly bimodal with about half of the detections between 18 and 31 May and most of the rest after 10 June. The final May groups had scattered McNary Dam passage distributions with most detections after 10 June (Appendix Tables 3e-3i): 


\section{SUMMARY}

1. In general, assumptions of the statistical methodology used in the 1991 and 1992 studies were not violated, and maximum likelihood estimates (MLEs) derived were deemed valid.

2. For yearling chinook and coho salmon in 1991 and 1992, significant mortality occurred in the Prosser Dam and Chandler facility system only for fish passing through the Chandler Canal and facility. For much of the time and for most conditions tested, this mortality was estimated at approximately $7-16$ and $11 \%$ for yearling chinook and coho salmon, respectively. However, after mid-May 1992, when Chandler Canal water temperatures exceeded $15^{\circ} \mathrm{C}\left(59^{\circ} \mathrm{F}\right)$ and water flow was less than $30.0 \mathrm{cms}(1060 \mathrm{cfs})$, yearling chinook salmon mortality increased significantly to $63 \%$. Avian predation at the Chandler facility outfall may have contributed to this mortality (personal observations of the authors and Chandler facility staff) but its effect was not assessed in these studies. Only 5 valid tests were conducted in this time period for yearling chinook salmon and only 11 total tests were conducted for coho salmon.

3. The relationship between proportion of water flow diverted into the Chandler Canal (Fl) and proportion of fish entrained into the canal (Fi) for yearling chinook salmon was high $\left(R^{2}=0.86\right)$, but for coho salmon was low $\left(R^{2}=0.23\right)$. Further, predicted entrainment estimates had fairly low precision, did not cover all possible flows, and required adjustment for expected Chandler Canal-to-facility survival. 
4. Expanded detection proportion estimates of Chandler Canal survival were quite similar to the maximum likelihood estimates, and the EDP method can be used in future studies as long as the efficiency of the Chandler facility main PIT-tag detector can be estimated.

5. Relative recapture estimates of the Chandler Canal fish entrainment proportion were quite similar to the maximum likelihood estimates, and the RR method can be used in future studies as long as $100 \%$ survival can be assumed in the Prosser Dam forebay.

6. The efficiency of the Chandler facility main PIT-tag detector was estimated as exceeding $95 \%$ over both studies. However, there were at least three occasions when the detector was apparently inoperative for several hours, and these malfunctions seriously compromised detection data for study fish released during those times.

7. Most of the PIT-tagged fish released in the Prosser Dam forebay and the Chandler Canal passed the Chandler facility in a few hours. Median travel times to McNary Dam decreased over time from as long as 17 days in early April to as short as 6 days in early May for yearling chinook salmon and from 5 days in early May to 3 days in late May for coho salmon.

\section{RECOMMENDATIONS}

1. If precise survival estimates in the Yakima River system are required, additional survival studies over broad ranges of environmental conditions should be conducted to clarify and substantiate the results obtained in the 1991 and 1992 studies. A primary objective should be assessment of mortality factors related to passage through the Chandler Canal and facility. 
2. Further Chandler Canal fish entrainment proportion estimates are necessary to improve the precision and accuracy of the estimated fish/flow entrainment relationship.

3. High efficiency of the Chandler facility PIT-tag detection system should be maintained and detector malfunctions or downtime should be fully documented. 



\section{REFERENCES}

Burnhiam, , K. P., D. R. Anderson, G. C. White, C. Brownie, and K. H. Pollock. 1987. Design and analysis methods for fish survival experiments based on release-recapture. Am. Fish. Soc. Monogr. 5:1-437.

Hogg, R. V., and A. T. Craig. 1978. Introduction to Mathematical Statistics. 4th ed. Macmillan, New York, 438p.

Kendall, M. G. and A. Stuart. 1977. The Advanced Theory of Statistics. Vol. 2, 4th ed. Macmillan, New York, 472p.

Mehta, C., and N. Patel. 1992. StatXact ver. 2.0. Statistical Software for Exact Nonparameteric Inference. User's Manual. Cytel Software Corp., Cambridge, MA.

Mood, A. M., F. A. Graybill, and D. C. Boes 1974. Introduction to the Theory of Statistics, 3rd ed. McGraw-Hill Book Co., New York, 564p.

Prentice, E. F., T. A. Flagg, C. S. McCutcheon, D. F. Brastow, and D. C. Cross. 1990.

Equipment, methods, and an automated data-entry station for PIT tagging. Am. Fish.

Soc. Symp. 7:335-340.

Ruehle, T. E., and C. S. McCutcheon. 1994. PIT-tag studies with juvenile salmonids at the Chandler Canal fish collection facility, Yakima River, 1990. Report to Bonneville Power Administration, Contract DE-AI79-90PP-0799 37 p. + Appendices. (Available from Northwest Fisheries Science Center, 2725 Montlake Blvd. East, Seattle, WA 98112.)

Seber, G. A. F. 1982. Estimation of Animal Abundance and Related Parameters, 2nd ed. Oxford University Press, New York, 654p.

USACE (U.S. Army Corp of Engineers). 1991. Annual fish passage report--1991.

Columbia/Snake River projects, North Pacific Division. (Available from U.S. Army Corps of Engineers, P.O. Box 2946, Portland, OR 97208.)

Weisberg, S. 1985. Applied Linear Regression, 2nd ed. John Wiley \& Sons, New York 324p. 



\section{APPENDIX 1}

Initial estimates for the iterative likelihood models used in these studies were obtained using method-of-moment (MOM) estimators. MOM estimators were derived by setting the . detection history totals equal to their expected values and then solving the equations simultaneously for the various parameters (Hogg and Craig 1978). The MOM estimators presented below applied to the 1991 experimental design. Some of the 1992 MOM estimators were identical to the 1991 estimators, while others were somewhat different as they incorporated information from additional release locations R5 and R6 (as defined in the text). The resulting MOM estimates from the observed data are presented in Appendix Tables 6 and 7.

The parameter notation for the following equations were defined in the text. Parameters were uppercase while MOM estimators were lowercase. The detection history totals were defined as $x_{i j k}$, where ijk were the detection histories defined in the text. Although the sizes of the release groups on the same day were not always equal (i,e., due to slightly different tagging and mortality numbers), they were similar enough that they were assumed equal for algebraic simplicity in solving the MOM equations, and the average release number, $\mathrm{R}$, was used.

The following equations were used to obtain MOM estimators for 1991 (Note that detection totals $\mathbf{x}_{i 00}$ were not needed to obtain the solutions):

$$
\begin{aligned}
& \mathbf{x}_{111}=R S_{1} D S_{2} P S_{a} S_{m 1} \\
& x_{110}=R S_{1} D S_{2} P\left(1-S_{a} S_{m 1}\right) \\
& x_{101}=R S_{1} S_{m 1}\left(D S_{2}(1-P) S_{a}+(1-D) S_{3}\right) \\
& x_{211}=R S_{2} P S_{2} S_{m 1} \\
& x_{210}=R S_{2} P\left(1-S_{2} S_{m 1}\right) \\
& \mathbf{x}_{201}=R S_{2}(1-P) S_{2} S_{m 1} \\
& x_{31}=R S_{3} S_{m 1} \\
& x_{41}=R S_{m 1}
\end{aligned}
$$


The MOM estimators for the initial 1991 maximum likelihood iterative estimates were then derived as:

$$
\begin{aligned}
& s_{\mathrm{ml}}=\mathrm{x}_{41} / \mathrm{R} \\
& \mathrm{s}_{3}=\mathrm{x}_{31} / \mathrm{x}_{41} \\
& \mathrm{p}=\mathrm{x}_{211} /\left(\mathrm{x}_{201}+\mathrm{x}_{211}\right) \\
& \mathrm{s}_{2}=\left(\mathrm{x}_{210}+\mathrm{x}_{211}\right) / \mathrm{Rp} \\
& \mathrm{s}_{\mathrm{a}}=\mathrm{x}_{211} /\left(\left(\mathrm{x}_{210}+\mathrm{x}_{211}\right) \mathrm{s}_{\mathrm{ml}}\right) \\
& \left.\mathrm{d}=1 /\left(\left(\left(\mathrm{x}_{101}+\mathrm{x}_{111}\right) / \mathrm{x}_{111}\right)-(1 / \mathrm{p})\right)\left(\mathrm{x}_{211} / \mathrm{x}_{31}\right)+1\right) \\
& \mathrm{s}_{1}=\left(\mathrm{x}_{110}+\mathrm{x}_{111}\right) / \mathrm{D}\left(\mathrm{x}_{210}+\mathrm{x}_{211}\right)
\end{aligned}
$$




\section{APPENDIX 2}

Maximum Likelihood estimates for S1, S2, P, and Chandler facility travel times for 7 May 1991, 7 April 1992, and 12 May 1992 were different from the estimates for all other release days. The differences were substantial and similar between days. PIT-tag detections through time at the Chandler facility main PIT-tag detector were examined for these three and adjacent days. In all three cases, initial detections for R1 and R2 releases were much later than other days. Also, the two groups were detected together while on other release days, R2 fish were generally detected ahead of R1 fish. Following are detailed descriptions of the differences discussed above for the three affected release days. Comparisons involve only yearling chinook salmon releases.

\section{May 1991}

1. The average S1 estimate was 0.99 . The 7 May S1 estimate was 1.12 and was the only estimate over 1.03. The average $\mathrm{S} 2$ estimate was 0.97 . The 7 May S2 estimate was 0.77 and was the only estimate below 0.90 . The average $P$ estimate was 0.98 . The 7 May $P$ estimate was 0.60 and was the only estimate below 0.95 .

2. For R1 and R2 fish released on 7 May, 88 and 108 were not detected at the Chandler facility, respectively. The maximums for other $\mathbf{R} 1$ and $\mathbf{R} 2$ releases in May were 23 and 15 , respectively.

3. Minimum travel times for R1 and R2 fish released on 7 May were 2.4 and 2.7 hours, respectively. Other release days averaged 1.5 and 0.7 hours, respectively. The difference 
between median travel times for $\mathrm{R} 1$ and $\mathrm{R} 2$ fish released on 7 May was -0.6 hours. Other release days averaged 0.8 hours.

\section{April 1992}

1. The average April S1 estimate was 0.98 . The 7 April S1 estimate was 1.12 and was the only estimate over 1.03. The average April S2 estimate was 0.93. The 7 April S2 estimate was 0.82 and was the only estimate below 0.87 . The average April P estimate was 0.97 . The 7 April P estimate was 0.72 and was the only estimate below 0.95 .

2. For R1 and R2 fish released on 7 April, 47 and 61 were not detected at the Chandler facility, respectively. The maximums for other $\mathrm{R} 1$ and $\mathrm{R} 2$ releases in April were 31 and 17 , respectively.

3. Minimum travel times for R1 and R2 fish released on 7 April were 8.4 and 8.8 hours, respectively. Other release days averaged 2.8 and 1.7 hours, respectively. The difference between median travel times for $\mathrm{R} 1$ and $\mathrm{R} 2$ fish released on 7 April was -55.9 hours. Other release days averaged 0.4 hours.

\section{May 1992}

1. The average May S1 estimate was 1.06. The 12 May S1 estimate was 1.45 and was the only estimate over 1.11 . The average May $\mathrm{S} 2$ estimate was 0.58 . The 12 May S2 estimate was 0.31 and was the only estimate below 0.48 . There were no May P estimates.

2. For R1 and R2 fish released on 12 May, 76 and 84 were not detected at the Chandler facility, respectively. The maximums for other $\mathrm{R} 1$ and $\mathrm{R} 2$ releases in May were 65 and 63 , respectively. 
3. Minimum travel times for R1 and R2 fish released on 12 May were 6.0 and 6.2 hours, respectively. Other release days averaged 2.8 and 1.7 hours, respectively. The difference between median travel times for R1 and R2 fish released on 12 May was -5.3 hours.

Other release days averaged 0.4 hours. 
Appendix Table 1a. McNary Dam passage dates for yearling chinook salmon released one km above Prosser Dam in April 1991 and detected (D) or not detected (ND) at the Chandler facility.

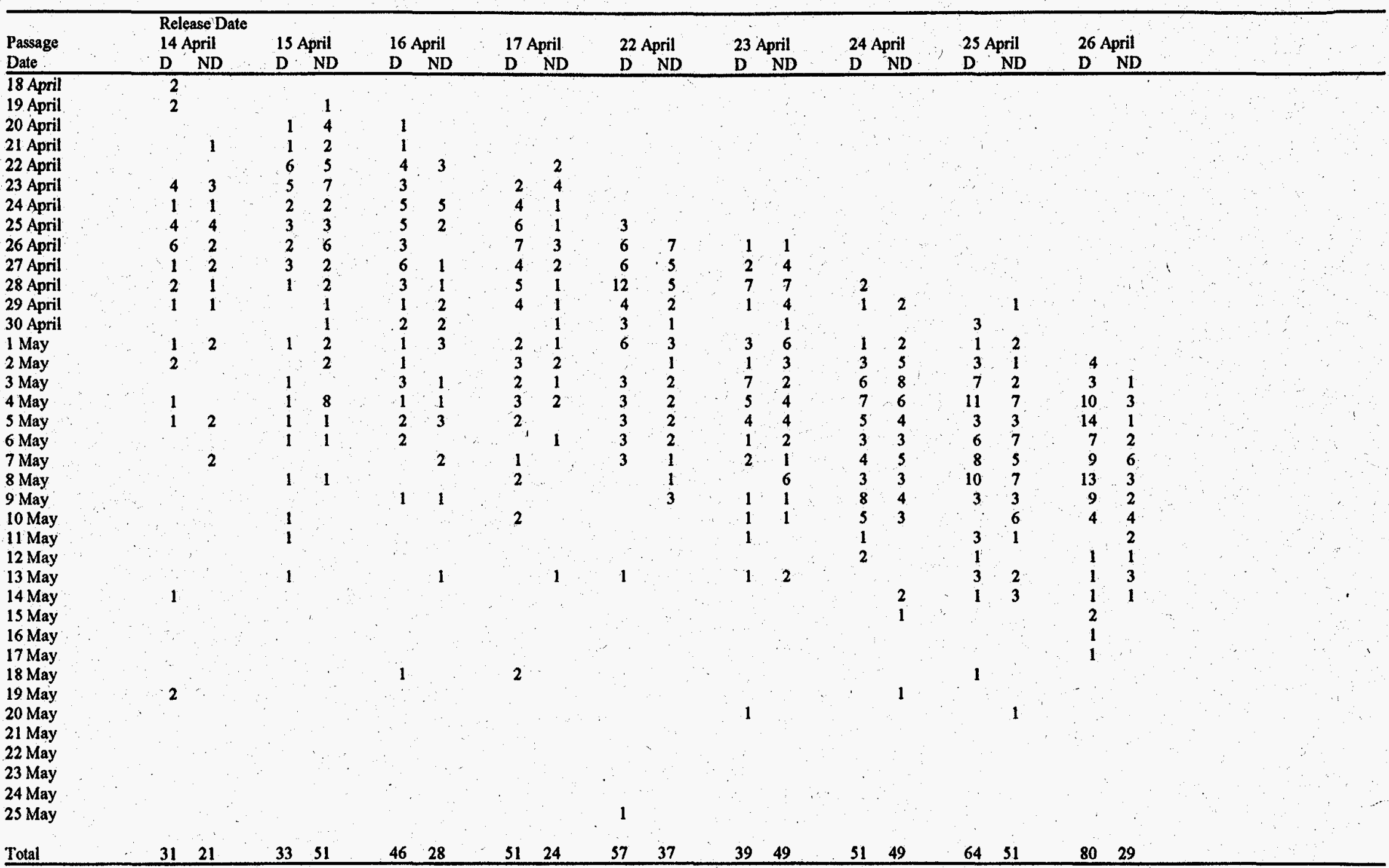


Appendix Table 1b. McNary Dam passage dates for yearling chinook and coho salmon released one km above Prosser Dam in May 1991 and detected (D) or not detected (ND) at the Chandler facility.

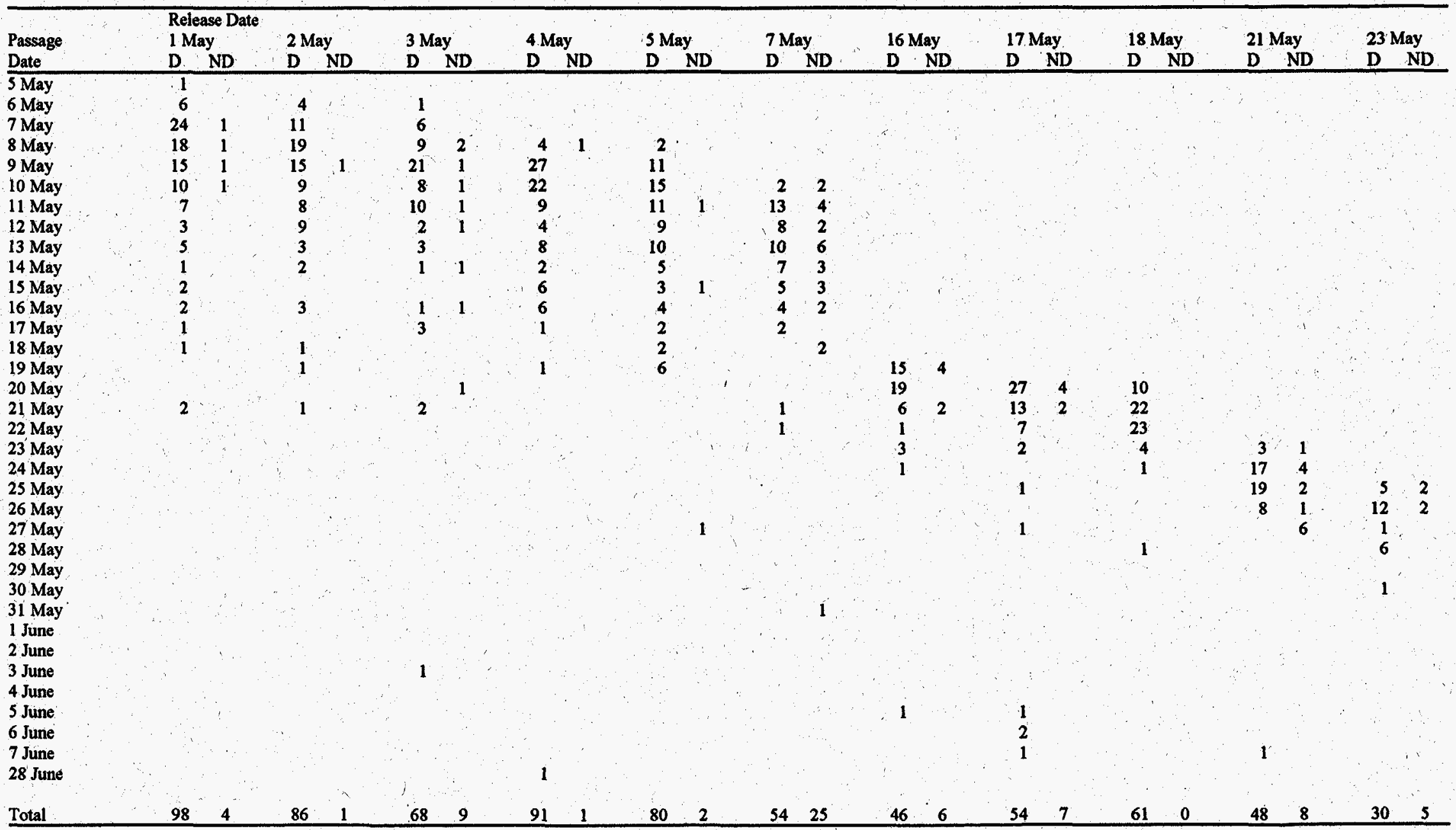


Appendix Table 1c. McNary Dam passage dates for yearling chinook salmon released one km above Prosser Dam in April 1992 and detected (D) or not detected (ND) at the Chandler facility.

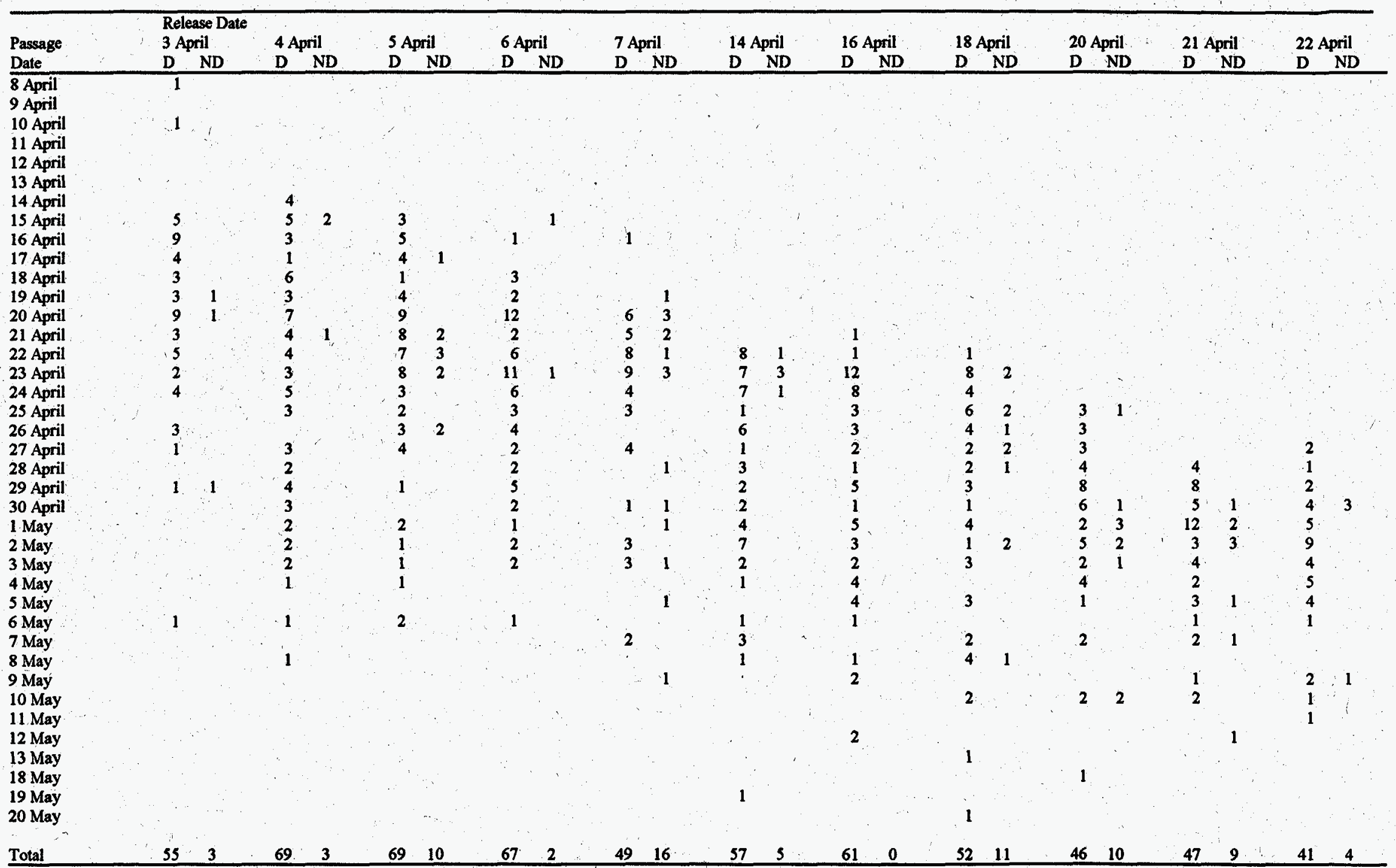


Appendix Table 1d. McNary Dam passage dates for coho salmon released one $\mathrm{km}$ above Prosser Dam in April and May 1992 and detected (D) or not detected (ND) at the Chandler facility.

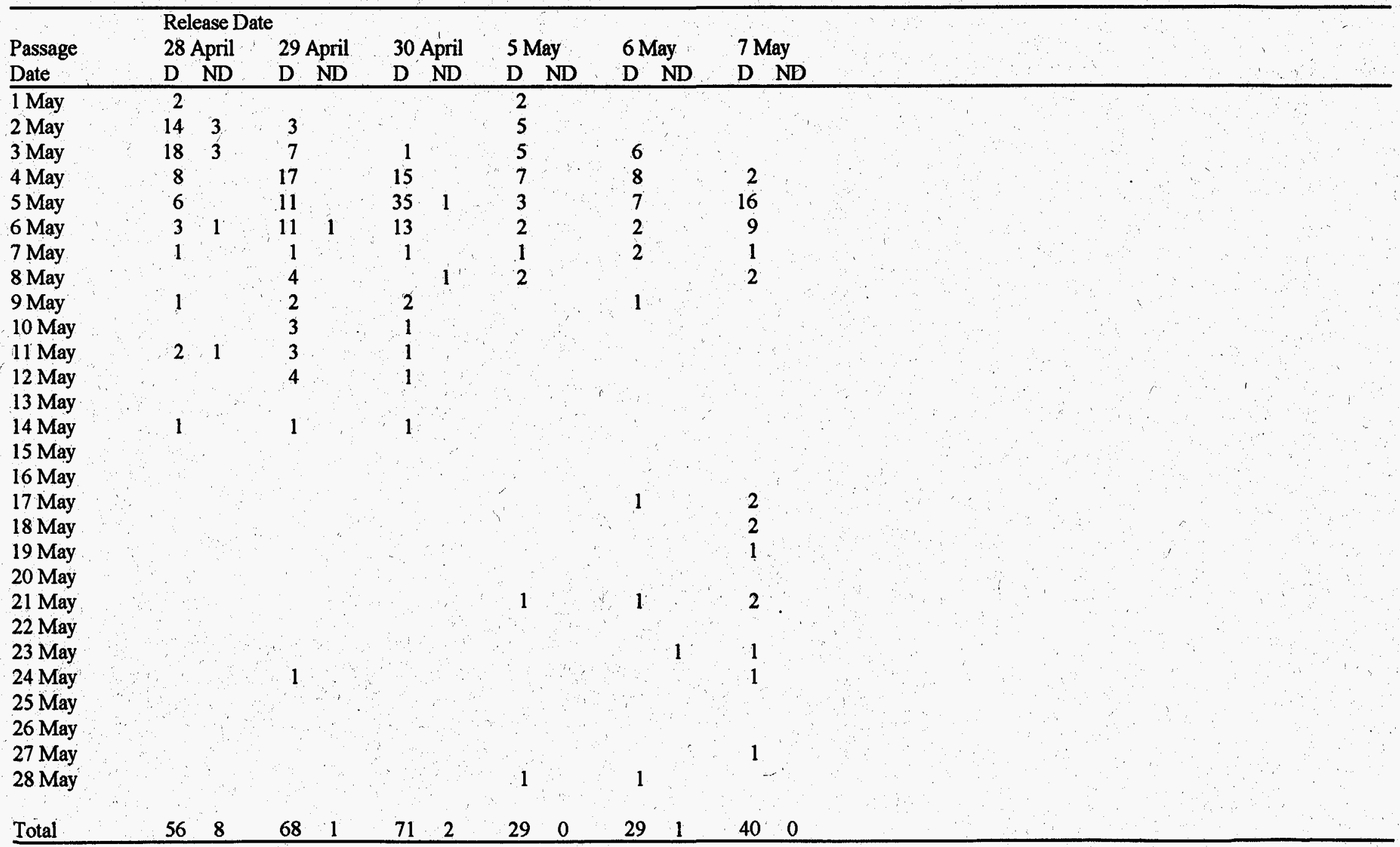


Appendix Táble 1e. McNary Dam passage dates for yearling chinook salmon released one $\mathrm{km}$ above Prosser Dam in May and June 1992 and detected (D) or not detected (ND) at the Chandler facility.

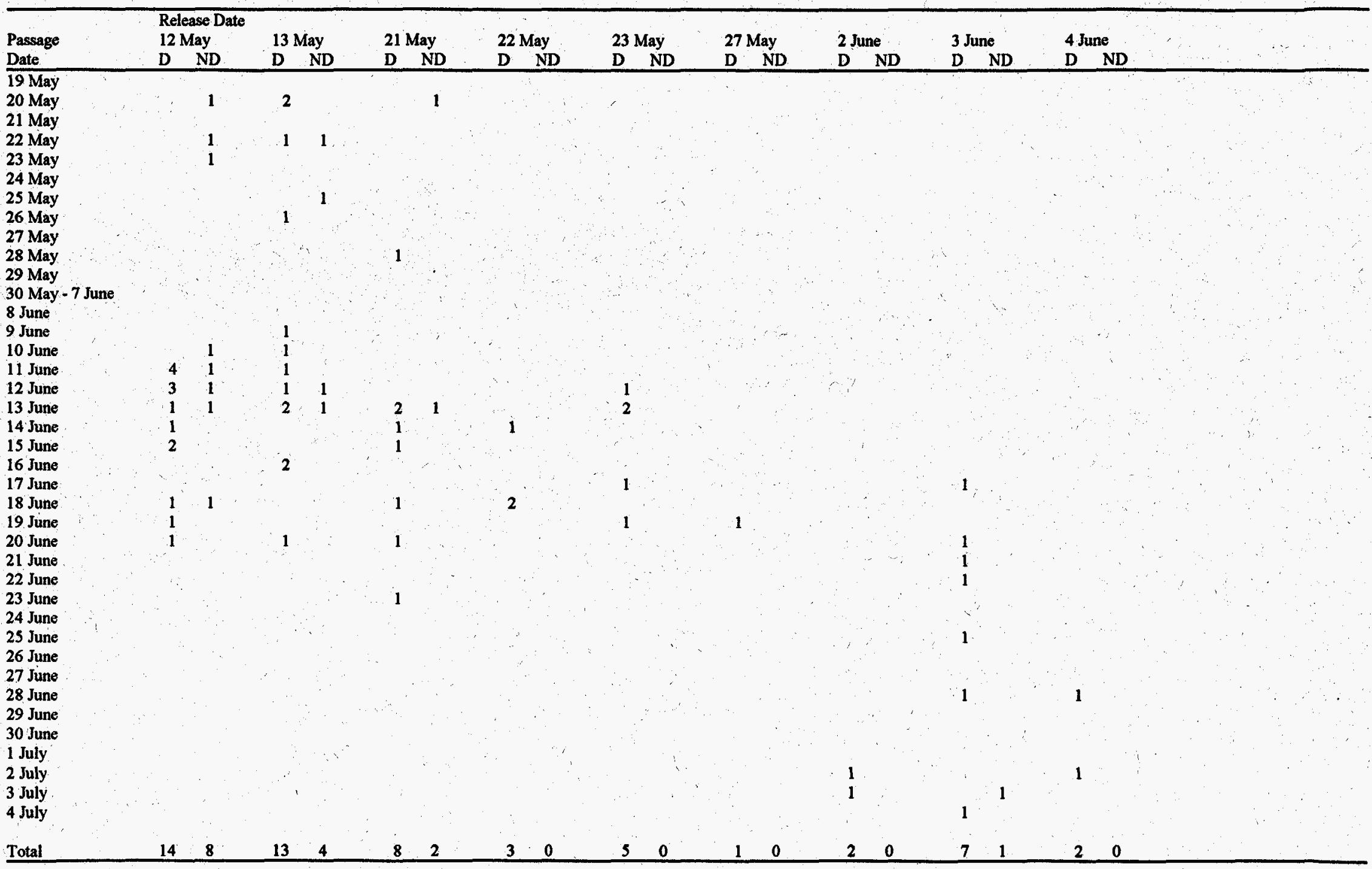


Appendix Table 2a. McNary Dam passage dates for yearling chinook salmon released one $\mathrm{km}$ above Prosser Dam or at the headworks of the Chandler Canal in April 1991 and sampled (S) or not sampled (NS) at the Chandler facility.

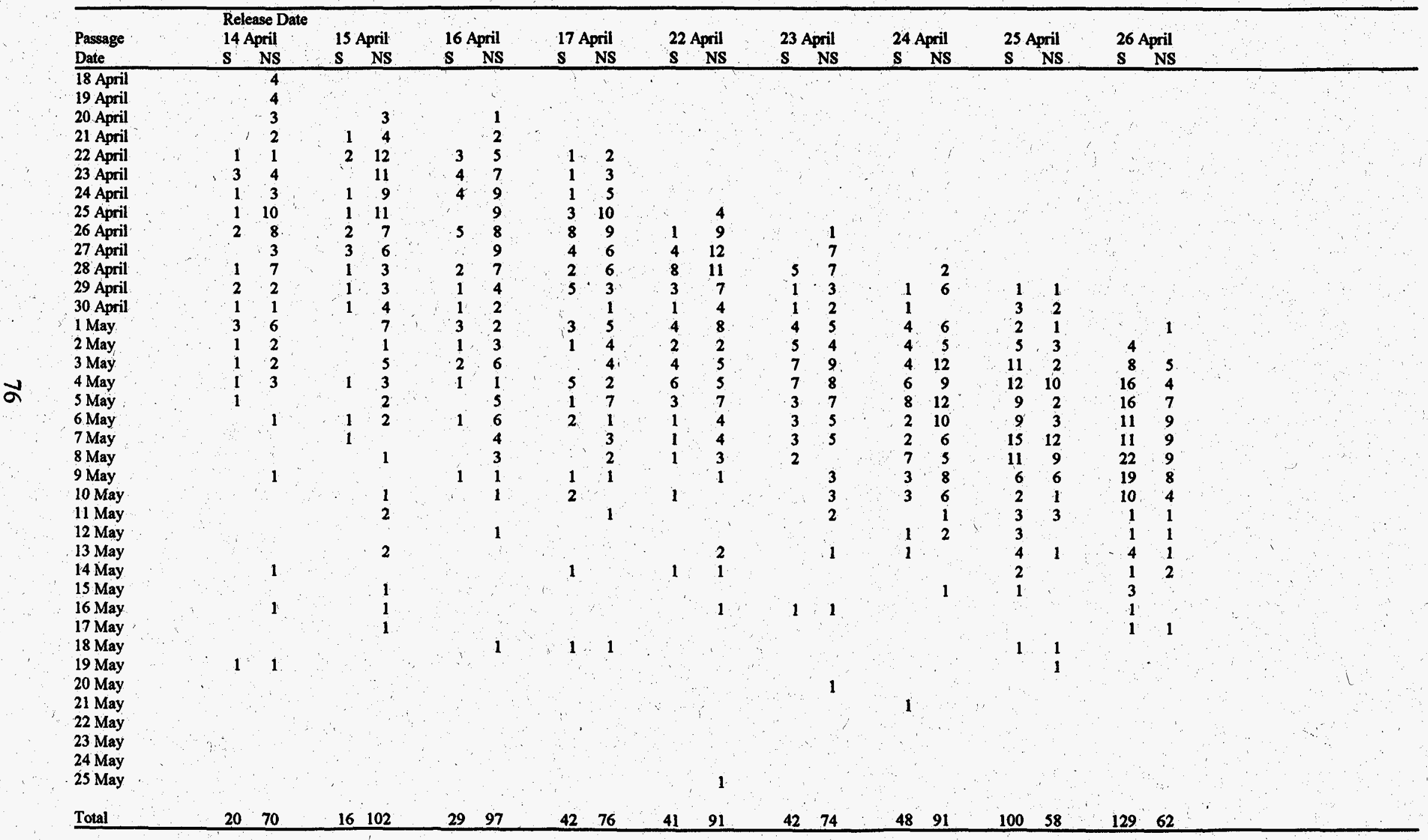


Appendix Table 2b. McNary Dam passage dates for yearling chinook and coho salmon released one $\mathrm{km}$ above Prosser Dam or at the headworks of the Chandler Canal in May 1991 and sampled (S) or not sampled (NS) at the Chandler facility.

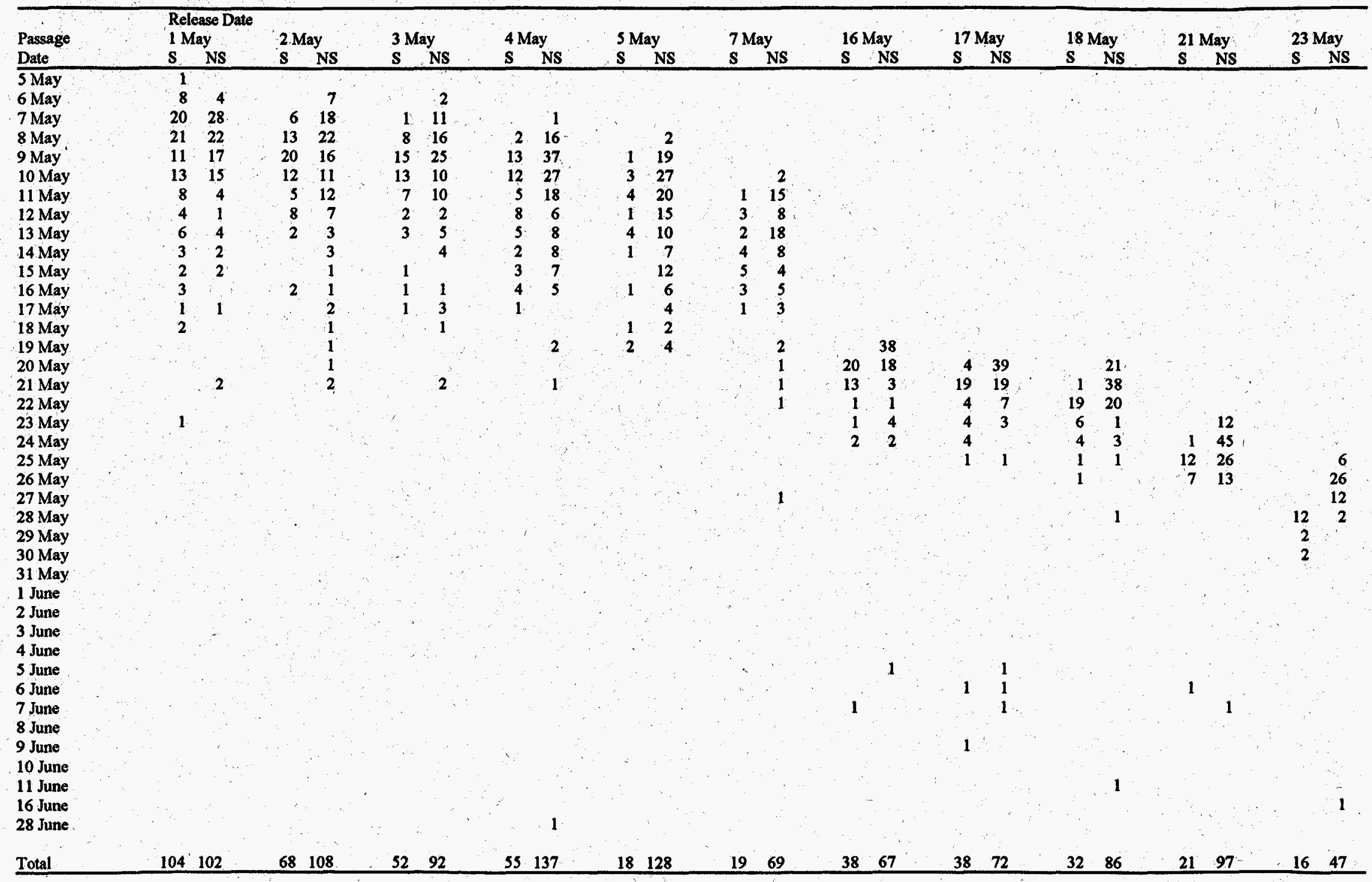


Appendix Table 2c. McNary Dam passage dates for yearling chinook salmon released one km above Prosser Dam or at the headworks of the Chandler Canal in April 1992 and sampled (S) or not sampled (NS) at the Chandler facility.

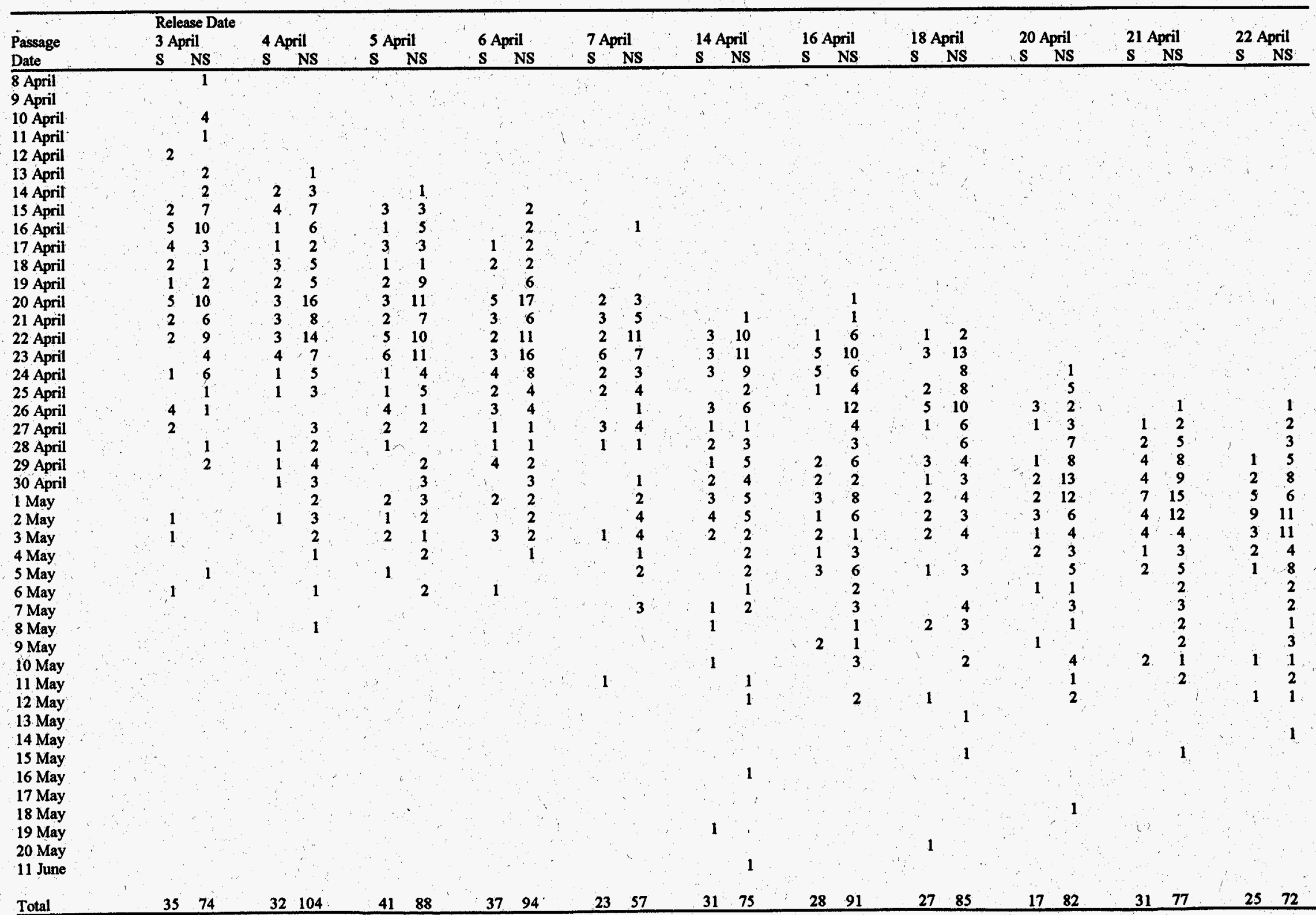


Appendix Table 2d. McNary Dam passage dates for coho salmon released one $\mathrm{km}$ above Prosser Dam or at the headworks of the Chandler Canal in April and May 1992 and sampled (S) or not sampled (NS) at the Chandler facility.

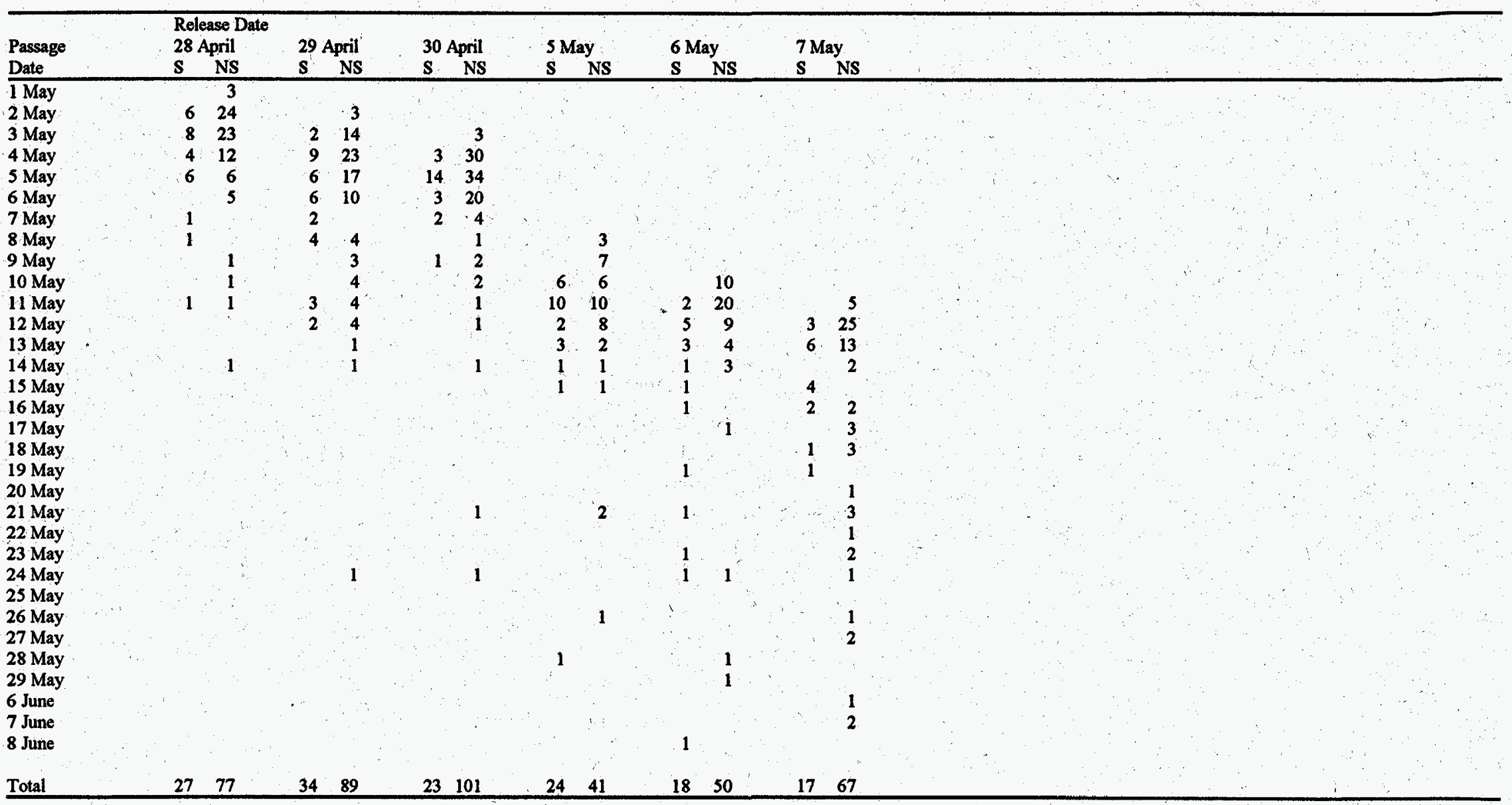


Appendix Table 2e. McNary Dam passage dates for yearling chinook salmon released one $\mathrm{km}$ above Prosser Dam or at the headworks of the Chandler Canal in May and June 1992 and sampled (S) or not sampled (NS) at the Chandler facility.

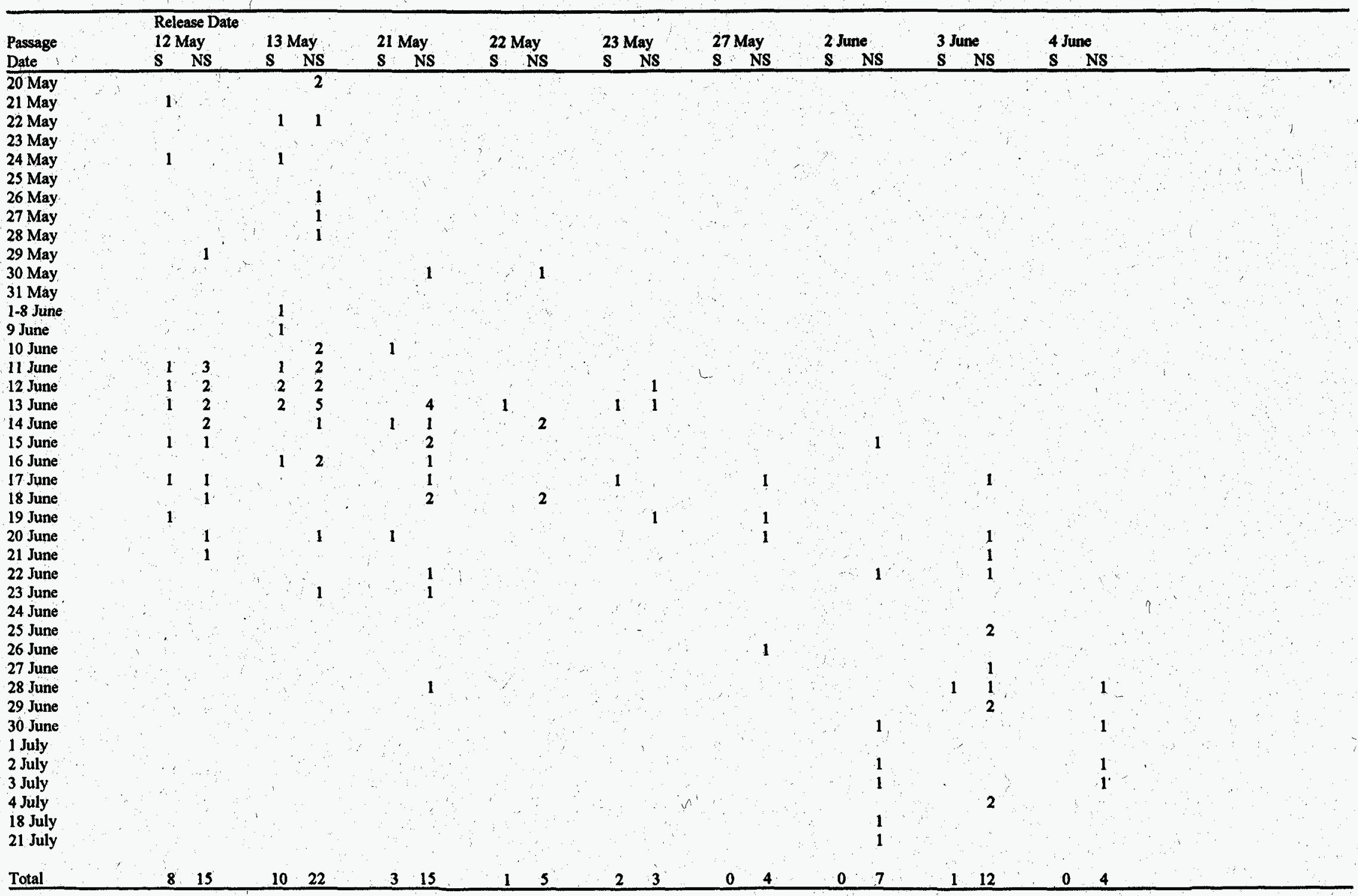


Appendix Table 3a. McNary Dam passage dates for yearling chinook salmon released one $\mathrm{km}$ above Prosser Dam (R1), at the headworks of the Chandler Canal (R2), immediately below Prosser Dam (R3), or at the Chandler facility outfall (R4) from 14-17 April 1991. Medians are in bold.

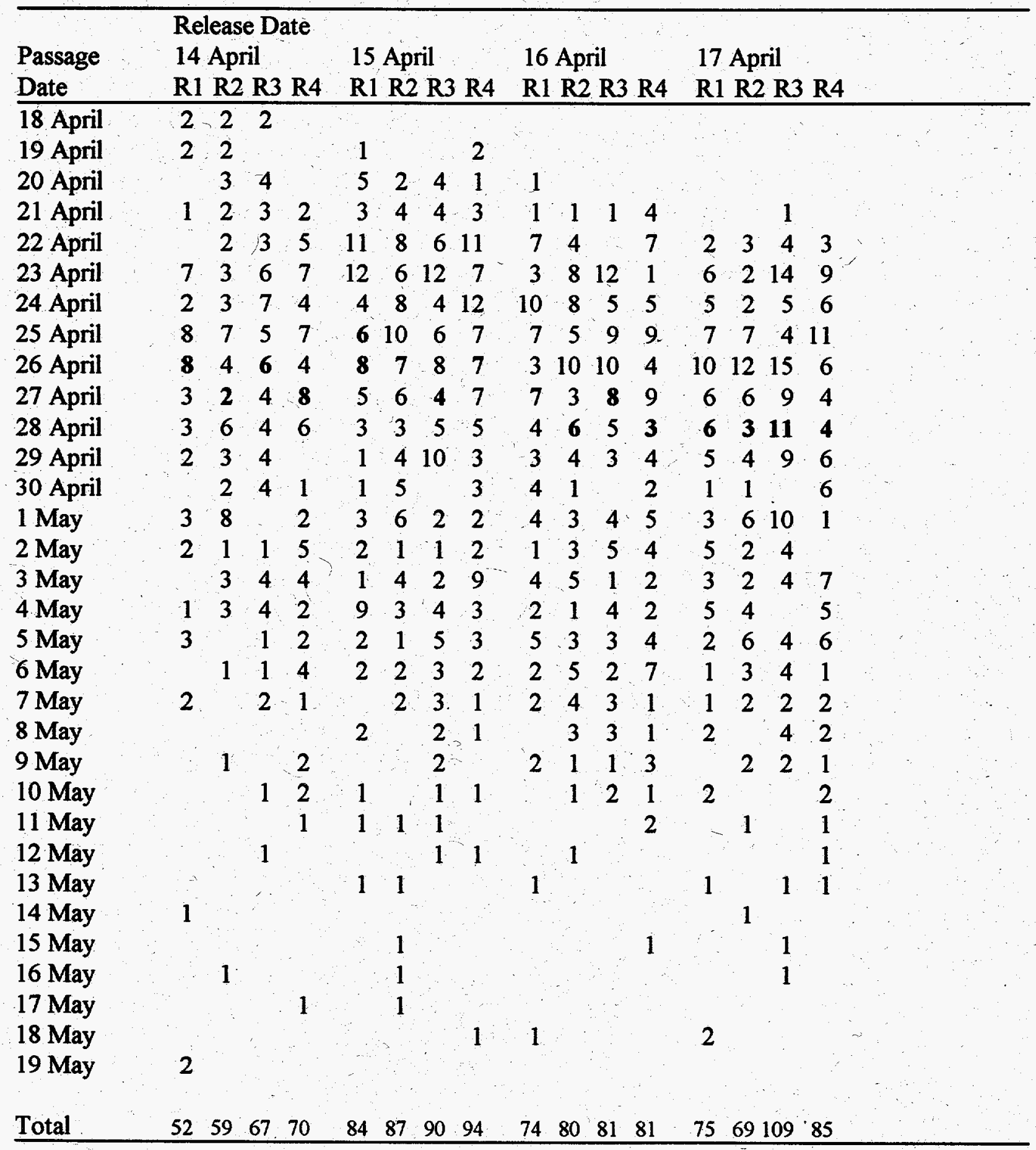


Appendix Table 3b. McNary Dam passage dates for yearling chinook salmon released one $\mathrm{km}$ above Prosser Dam (R1), at the headworks of the Chandler Canal (R2), immediately below Prosser Dam (R3), or at the Chandler facility outfall (R4) from 22-26 April 1991. Medians are in bold.

\begin{tabular}{|c|c|c|c|c|c|c|c|c|c|c|c|c|c|c|c|c|c|c|c|c|}
\hline $\begin{array}{l}\text { Passage } \\
\text { Date }\end{array}$ & $\begin{array}{c}\mathrm{Re} \\
22 \\
\mathrm{R} 1\end{array}$ & $\begin{array}{l}\text { Ap } \\
\text { R2 }\end{array}$ & $\mathbf{R}$ & $\mathbf{R} 4$ & & $\begin{array}{l}3 \mathrm{Ap} \\
1 \mathrm{R}\end{array}$ & ril & $\mathrm{R} 4$ & & $\begin{array}{l}4 \mathrm{Ap} \\
1 \mathrm{R} 2\end{array}$ & & & & $\begin{array}{l}A p \\
R^{\prime}\end{array}$ & & $3 \mathrm{R} 4$ & & $\begin{array}{l}6 \mathrm{Apr} \\
1 \mathrm{R} 2 \\
\end{array}$ & & \\
\hline 25 April & 3 & 1 & 3 & 2 & & & & & & & & & & & & & & & & \\
\hline 26 April & 13 & 4 & 14 & 9 & 2 & & 8 & 3 & & & & & & & & & & & & \\
\hline 27 April & 11 & 10 & 12 & 13 & 6 & 5 & 11 & 6 & & & & & & & & & & & & \\
\hline 28 April & 17 & 7 & 8 & 10 & 14 & 5 & 15 & 10 & 2 & & 4 & 3 & & & 1 & & & & & \\
\hline 29 April & 6 & 6 & 10 & 7 & 5 & 3 & 6 & 10 & 3 & 6 & 4 & 3 & 1 & 2 & 2 & 3 & & & & \\
\hline 30 April & 4 & 3 & 2 & 1 & 1 & 3 & 3 & 3 & & 1 & 2 & 2 & 3 & 2 & 2 & 1 & & & z & \\
\hline 1 May & 9 & 6 & 8 & 6 & 9 & 6 & 4 & 7 & 3 & 9 & 8 & 7 & 3 & 2 & 6 & & & 1 & 5 & \\
\hline 2 May & 1 & 4 & 10 & 4 & 4 & 8 & 3 & 14 & 8 & 6 & 10 & 4 & 4 & 5 & 6 & 10 & 4 & 4 & 5 & 4 \\
\hline 3 May & 5 & 6 & 4 & 6 & 9 & 9 & 9 & 10 & 14 & 10 & 12 & 7 & 9 & 6 & 14 & 13 & & 410 & 3 & 6 \\
\hline 4 May & 5 & 8 & 8 & 4 & 9 & 10 & 5 & 8 & 13 & 8 & 8 & 10 & 18 & 12 & 14 & 10 & 13 & 310 & 9 & 15 \\
\hline 5 May & 5 & 7 & 2 & 4 & 8 & 6 & 7 & 6 & 9 & 15 & 12 & 8 & 6 & 8 & 11 & 15 & 15 & 59 & 14 & 7 \\
\hline 6 May & 5 & 2 & 1 & 1 & 3 & 7 & 2 & 2 & 6 & 59 & 3 & 9 & 13 & 6 & 14 & 8 & & 913 & 13 & 7 \\
\hline 7 May & 4 & 2 & 1 & & 3 & 6 & 7 & 2 & 9 & 4 & 9 & 9 & 13 & 19 & 10 & 12 & 15 & 511 & 17 & 13 \\
\hline 8 May & 1 & 4 & 3 & 2 & 6 & 2 & & 5 & 6 & 9 & 9 & 7 & 17 & 10 & 10 & 19 & 16 & 619 & 19 & 22 \\
\hline May & 3 & 1 & 1 & 1 & 2 & 2 & 5 & & 12 & 4 & 8 & 11 & 6 & 9 & 5 & 10 & & 118 & 14 & 8 \\
\hline 10 May & & 1 & 1 & & 2 & 2 & & & 8 & 4 & 1 & 3 & 6 & 4 & 5 & 3 & & 810 & 6 & 9 \\
\hline 11 May & & & 1 & & 1 & 1 & & 3 & 1 & & 2 & 1 & 4 & 3 & 1 & 1 & & 2 & 1 & 7 \\
\hline 12 May & & & 1 & 1 & & & & & 2 & 1 & 1 & 3 & 1 & 2 & 1 & 1 & & 2 & 4 & 5 \\
\hline 13 May & 1 & 1 & & & 3 & & & & & 1 & & 1 & 5 & 2 & 1 & 2 & & 4 & 3 & 4 \\
\hline 14 May & & 2 & 1 & & & & & & 2 & & 1 & & 4 & 1 & 1 & 6 & & 2 & 1 & 1 \\
\hline 15 May & & & & & & & & & 1 & 1 & & & & 1 & 2 & 2 & & 1 & & 2 \\
\hline 16 May & & 1 & & & & 2 & & & & & & 1 & & & & & 1 & & & 1 \\
\hline 17 May & & & & & & & & & & & 2 & & & & & 1 & & 1 & 1 & 2 \\
\hline 18 May & & & & & & & 1 & & & & & & 1 & 1 & & & & & & 1 \\
\hline 19 May & & & & 1 & & & & & 1 & & & & & 1 & 1 & & & & & 2 \\
\hline 20 May & & & & & 1 & & & & & & & & 1 & & & & & & 1 & 1 \\
\hline 21 May & & & & 1 & & & & & & 1 & & & & & & & & & & \\
\hline 2 May & & & & & & & & & & & & & & & & & & & & \\
\hline 3 May & & & & & & & & & & & & & & & & & & & & \\
\hline 4 May & & & & & & & & & & & & & & & & & & & & \\
\hline 25 May & 1 & & & & & & & & & & & & & & & & & & & \\
\hline Total & 94 & 76 & 91 & 73 & 88 & 77 & 86 & 89 & 100 & 89 & 96 & $89^{\circ}$ & 115 & 96 & 107 & 117 & 109 & 91131 & 116 & 117 \\
\hline
\end{tabular}


Appendix Table 3c. McNary Dam passage dates for yearling chinook salmon released one km above Prosser Dam (R1), at the headworks of the Chandler Canal (R2), immediately below Prosser Dam (R3), or at the Chandler facility outfall (R4) from 1-7 May 1991. Medians are in bold.

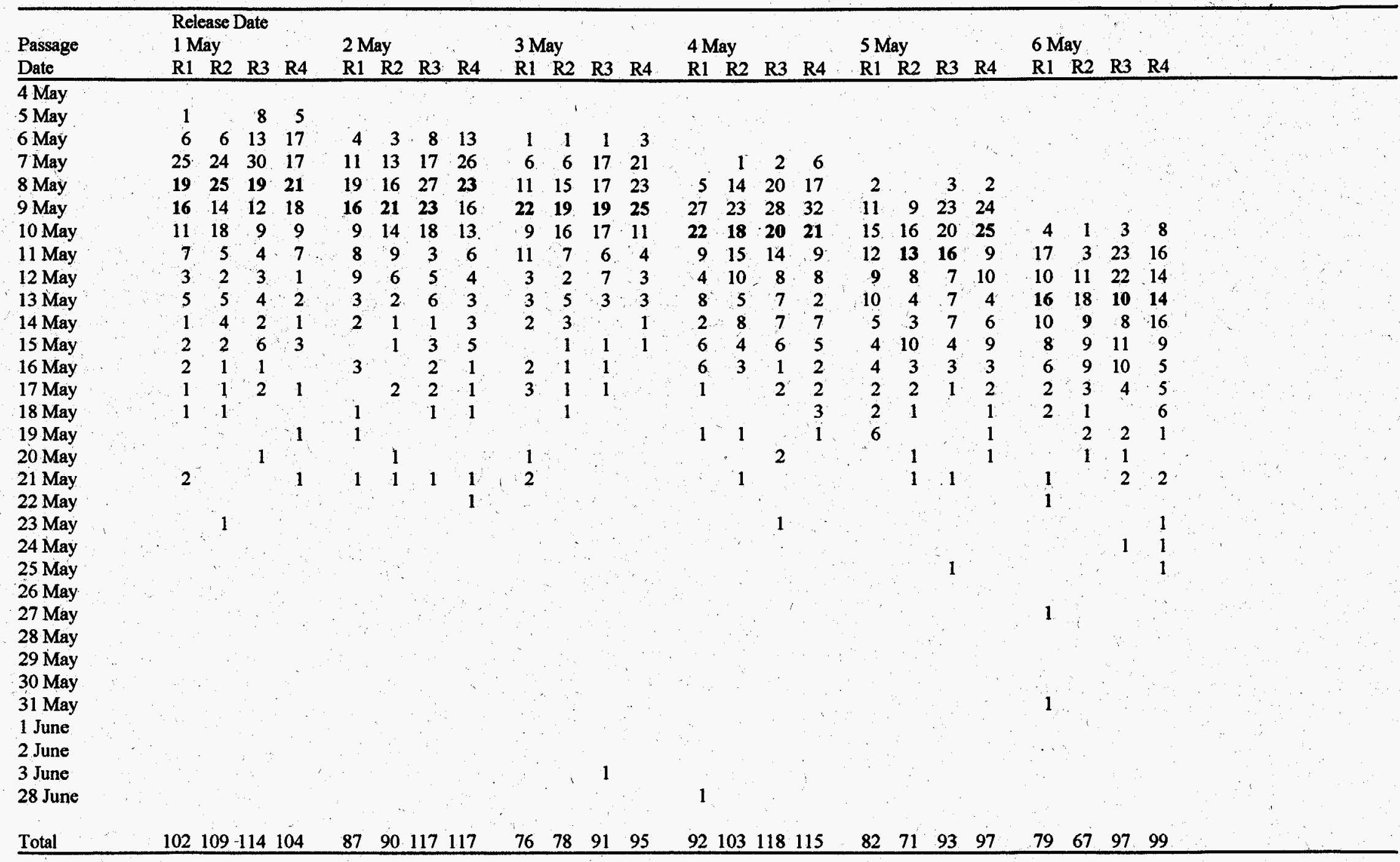


Appendix Table 3d. McNary Dam passage dates for coho salmon released one $\mathrm{km}$ above Prosser Dam (R1), at the headworks of the Chandler Canal (R2), immediately below Prosser Dam (R3), or at the Chandler facility outfall (R4) from 16-23 May 1991. Medians are in bold.

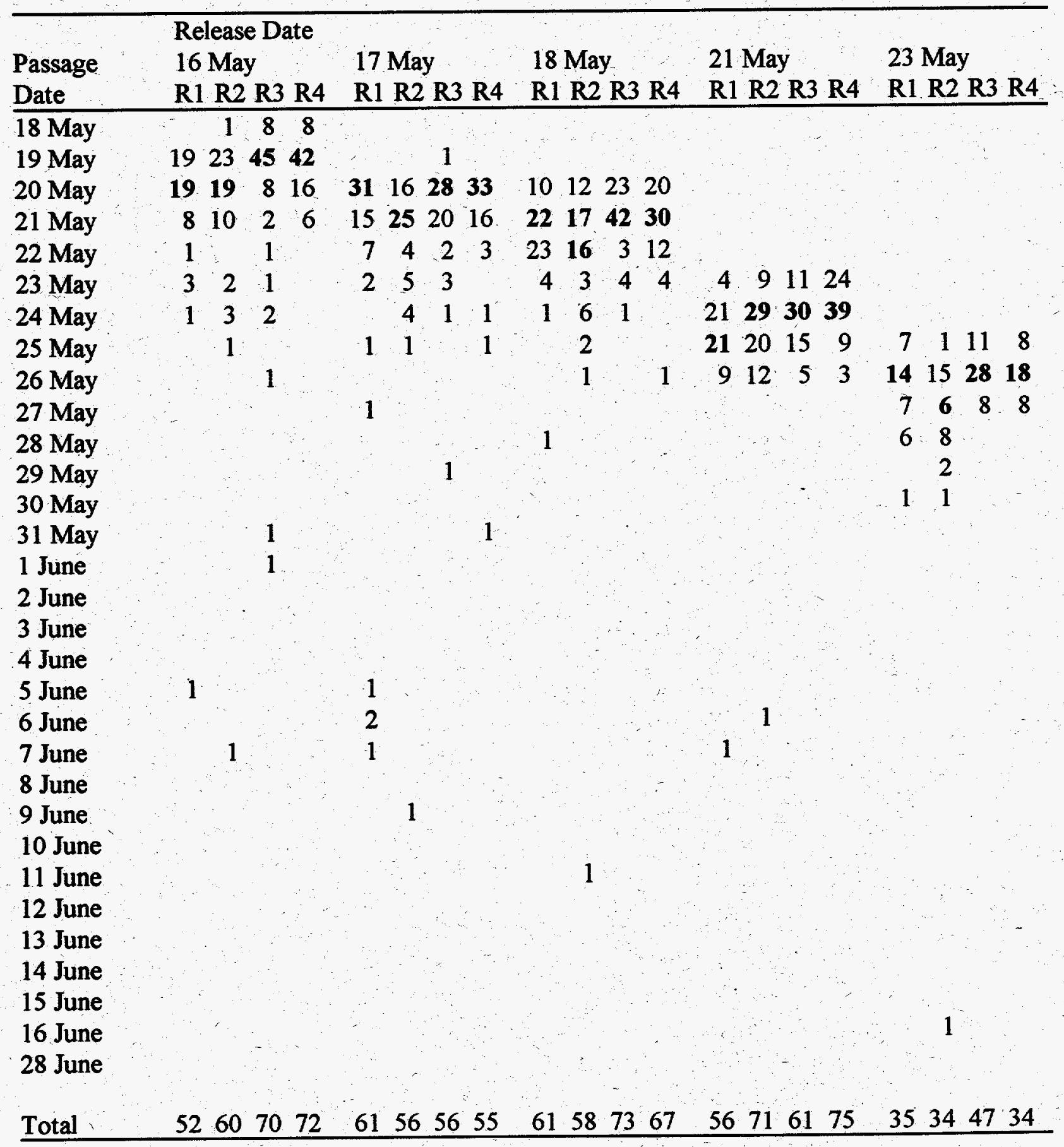


Appendix Table 3e. McNary Dam passage dates for yearling chinook salmon released one km above Prosser Dam (R1), at the headworks of the Chandler Canal (R2), immediately below Prosser Dam (R3), at the Chandler facility outfall (R4), or at the I-82 bridge (R5) from 3-7 April 1992. Medians are in bold.

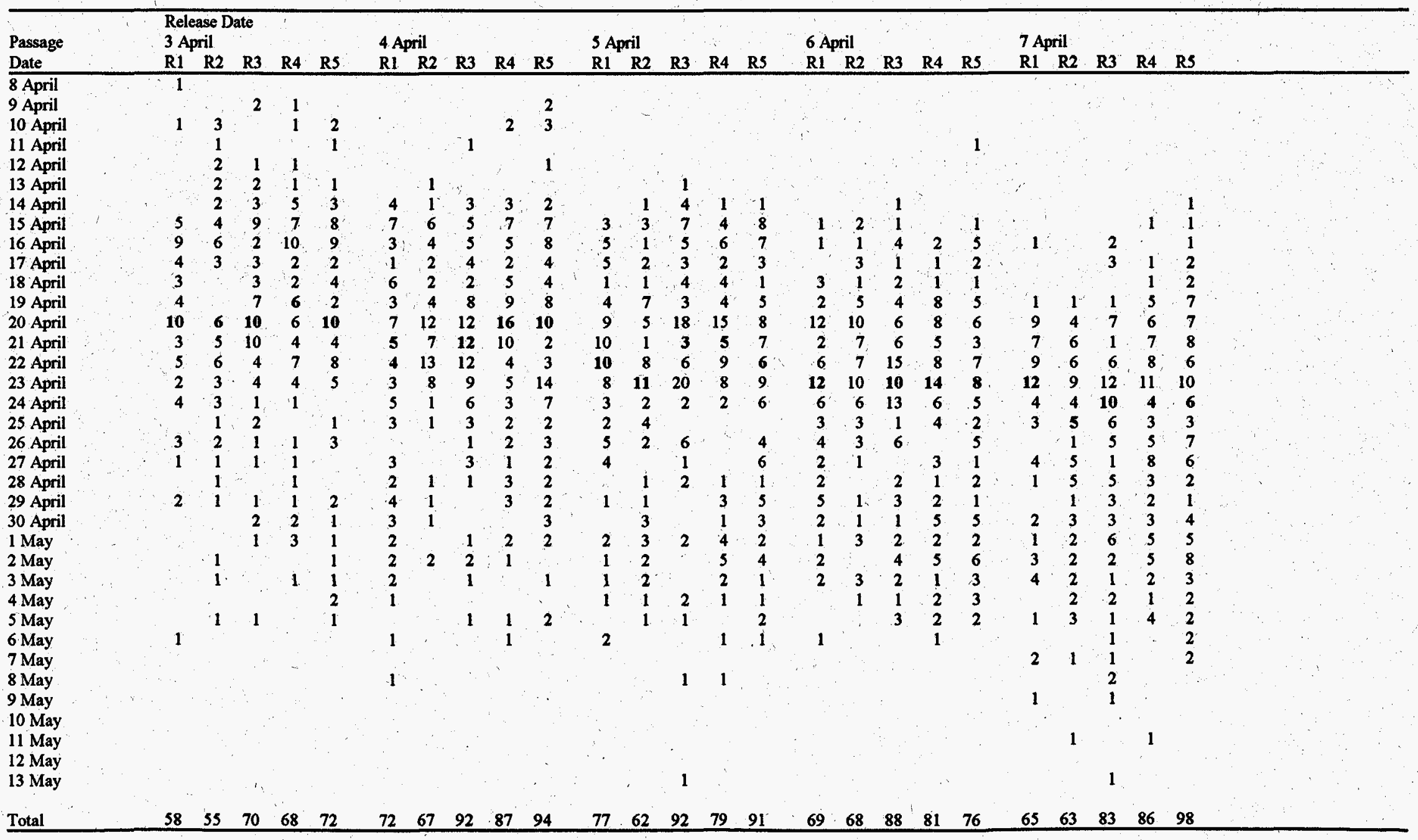


Appendix Table 3f. McNary Dam passage dates for yearling chinook salmon released one km above Prosser Dam (R1), at the headworks of the Chandler Canal (R2), immediately below Prosser Dam (R3), at the Chandler facility outfall (R4), at the I-82 bridge (R5), or immediately below the main PIT-tag detector in the Chandler facility (R6) from 14-22 April 1992. Medians are in bold.

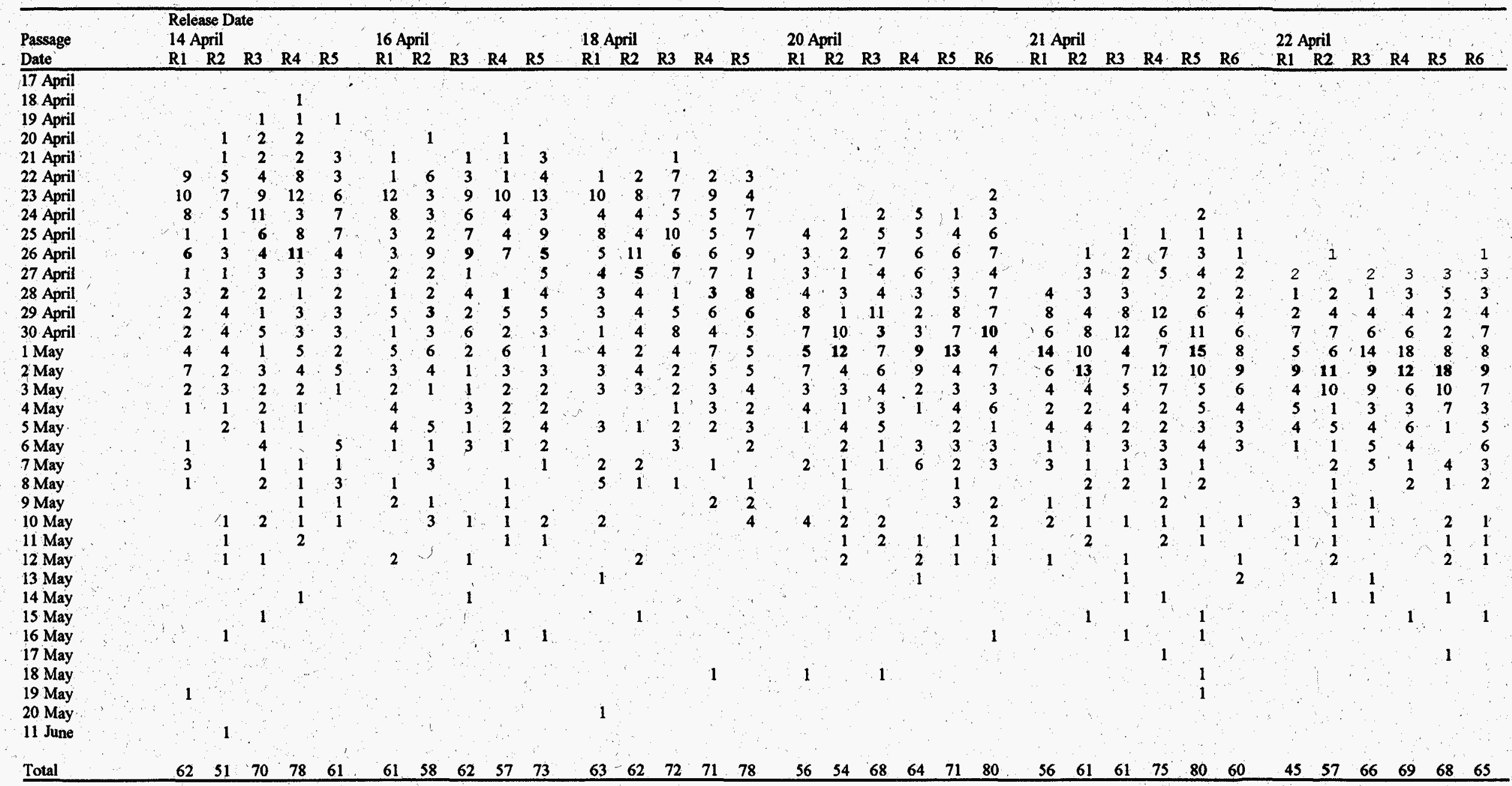


Appendix Table 3g. McNary Dam passage dates for coho salmon released one $\mathrm{km}$ above Prosser Dam (R1), at the headworks of the Chandler Canal (R2), immediately below Prosser Dam (R3), at the Chandler facility outfall (R4), at the I-82 bridge (R5), or immediately below the main PIT-tag detector in the Chandler facility (R6) from 28-30 April 1992. Medians are in bold.

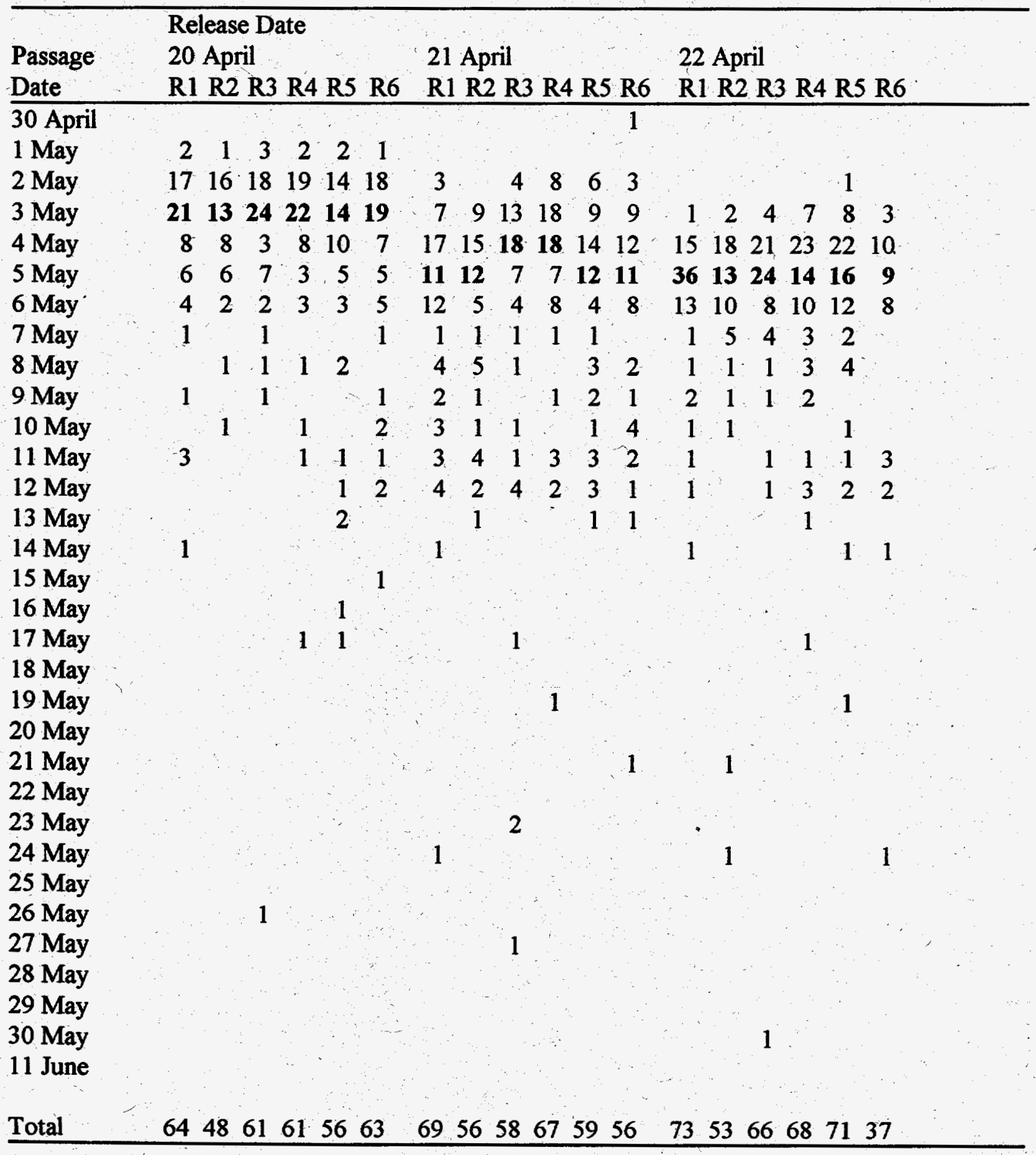


Appendix Table 3h. McNary Dam passage dates for coho salmon released one $\mathrm{km}$ above Prosser Dam (R1), at the headworks of the Chandler Canal (R2), immediately below Prosser Dam (R3), at the Chandler facility outfall (R4), at the I-82 bridge (R5), or immediately below the main PIT-tag detector in the Chandler facility (R6) from 5-7 May 1992. Medians are in bold.

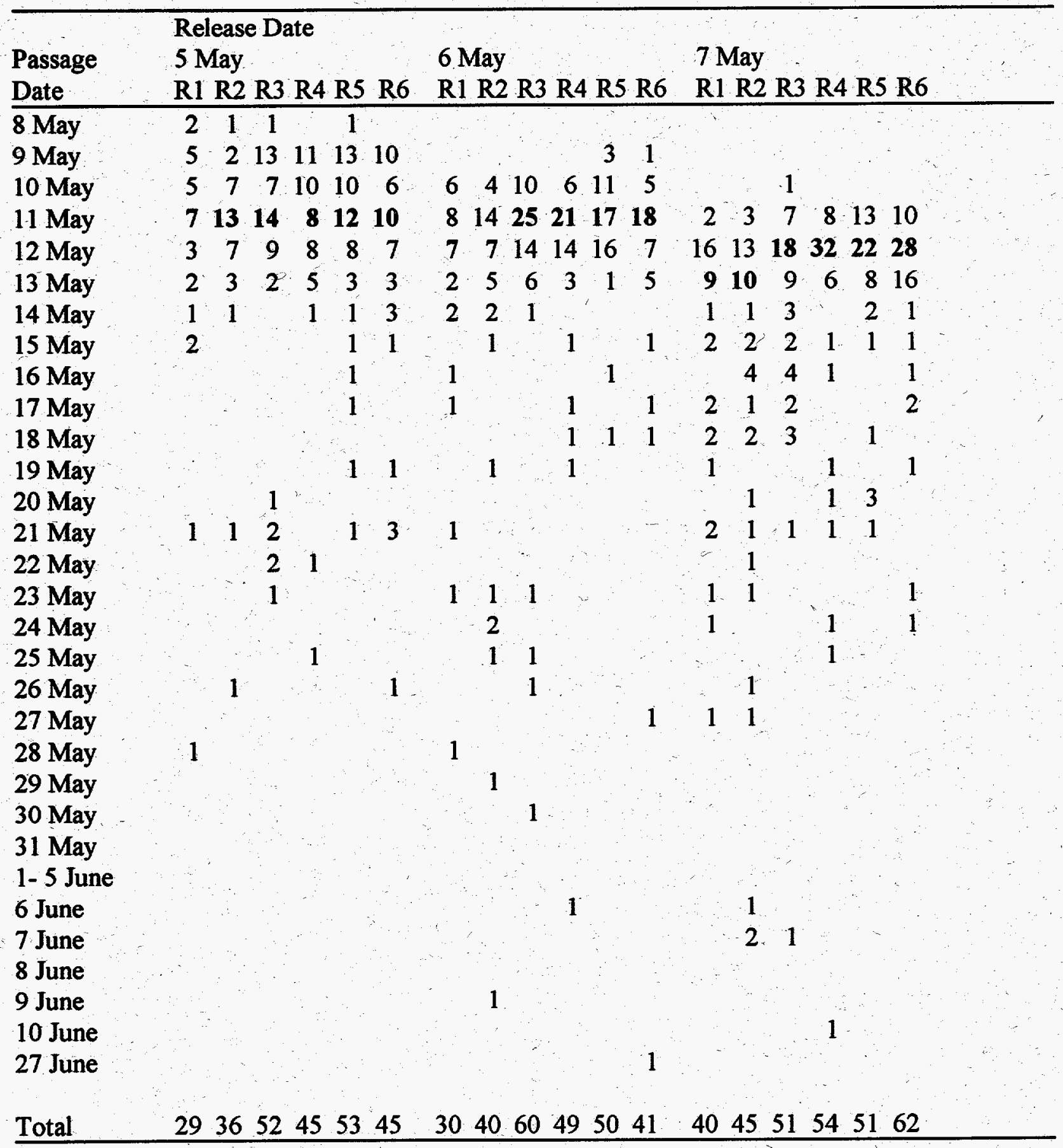


Appendix Table 3i. McNary Dam passage dates for yearling chinook salmon released one km above Prosser Dam (R1), at the headworks of the Chandler Canal (R2), immediately below Prosser Dam (R3), at the Chandler facility outfall (R4), or at the I-82 bridge (R5) from 12-27 May 1992. Medians are in bold.

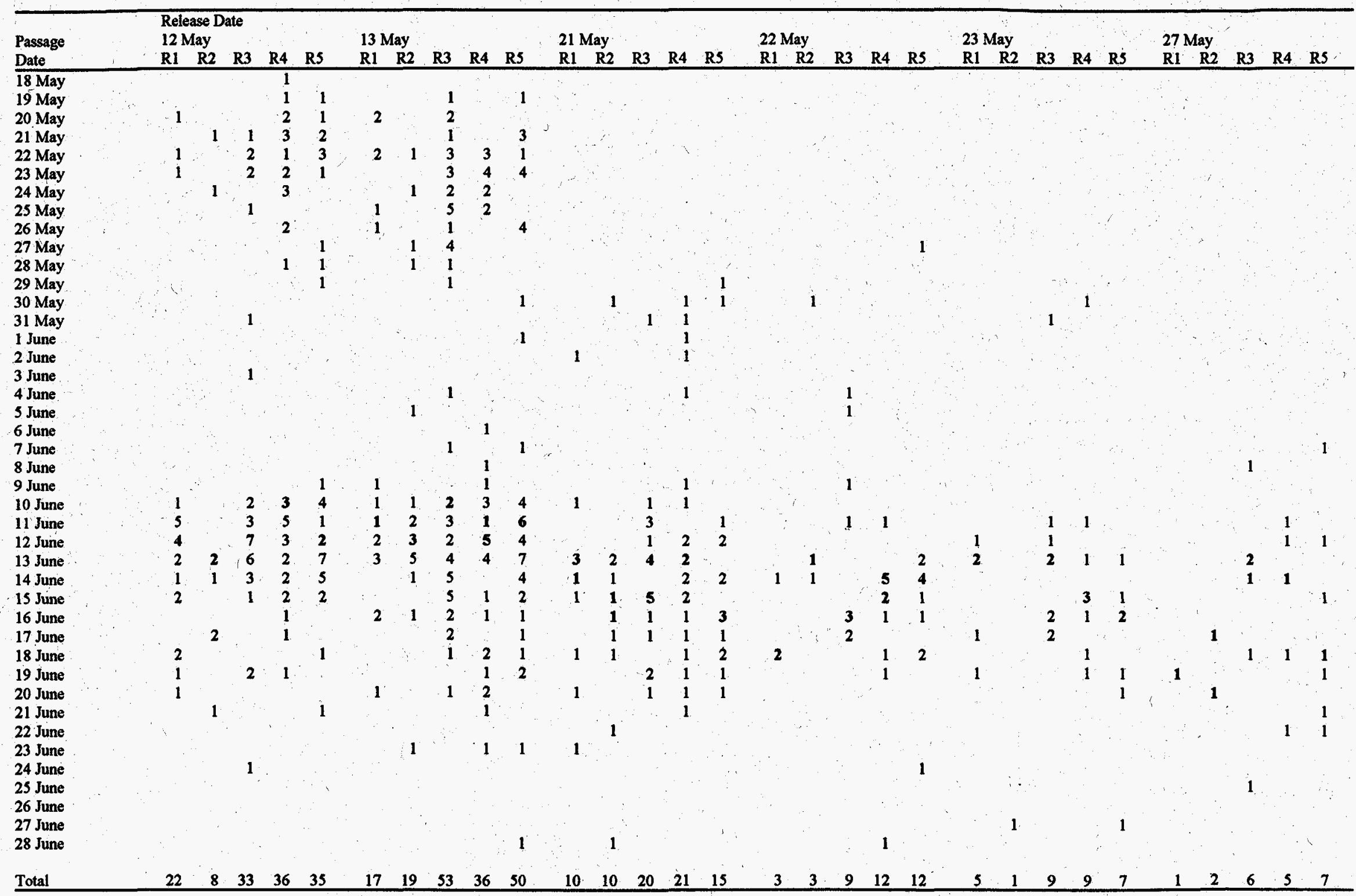


Appendix Table 3j. McNary Dam passage dates for yearling chinook salmon released one $\mathrm{km}$ above Prosser Dam (R1), at the headworks of the Chandler Canal (R2), immediately below Prosser Dam (R3), at the Chandler facility outfall (R4), or at the I-82 bridge (R5) in June 1992.

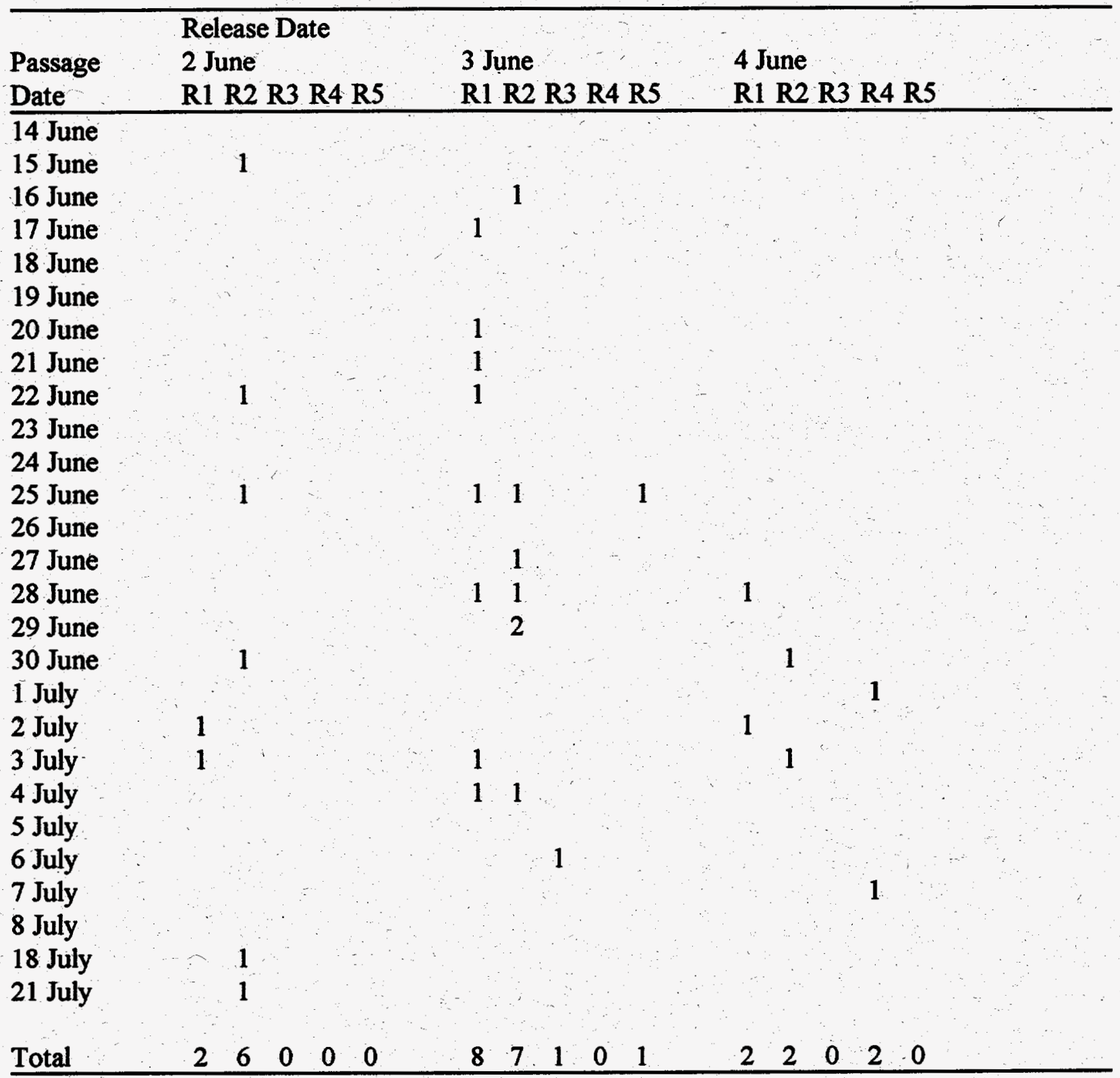


Appendix Table 4. Detection history totals for PIT-tagged yearling chinook and coho salmon released one km above Prosser Dam (R1), at the headworks of the Chandler Canal (R2), immediately below Prosser Dam (R3), or at the Chandler facility outfall (R4) in 1991. Abbreviations: CHF-Chandler facility; MCN-McNary Dam; Det-Detected.

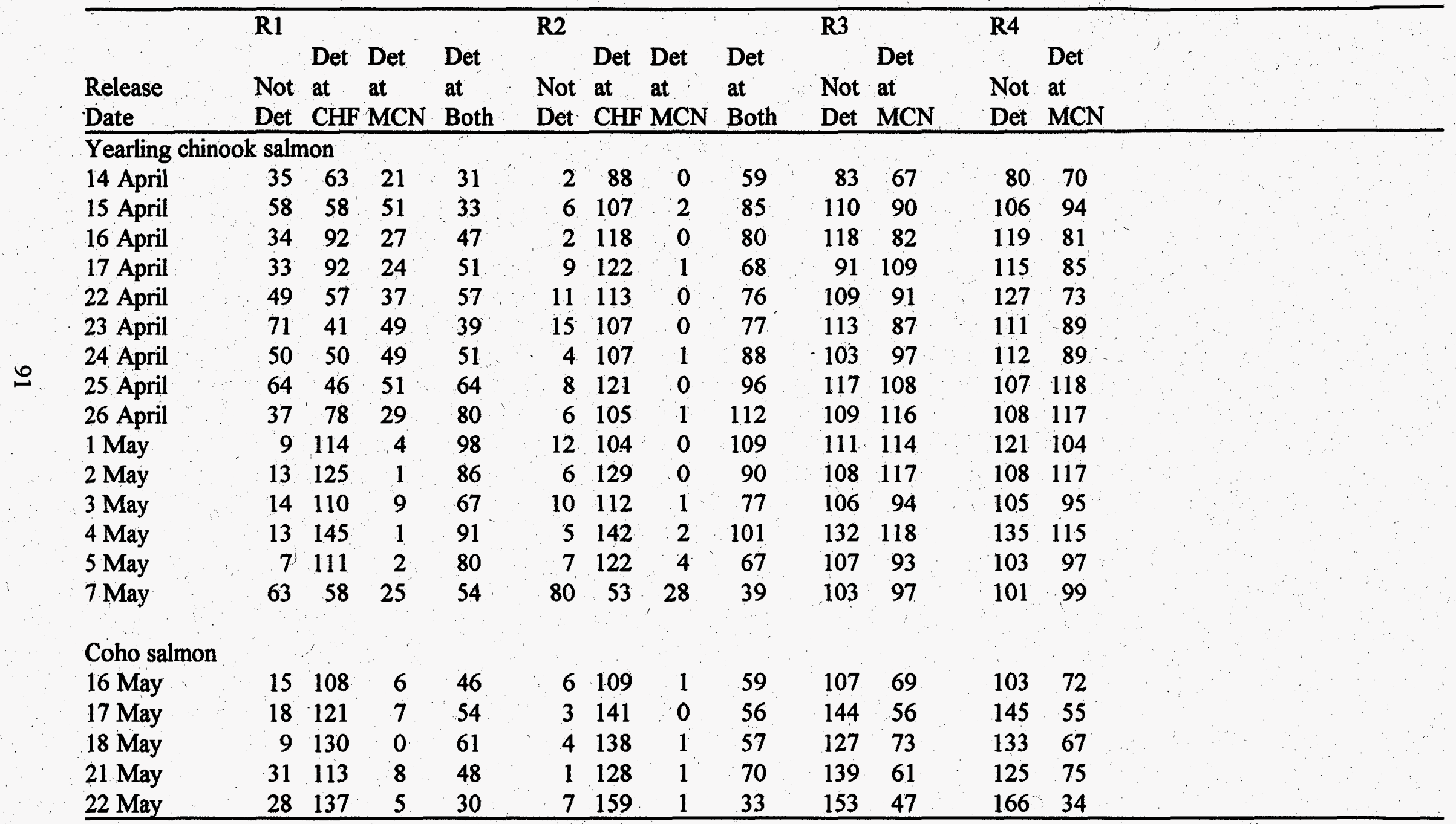


Appendix Table 5. Detection history totals for PIT-tagged yearling chinook and coho salmon released one km above Prosser Dam (R1), at the headworks of the Chandler Canal (R2), immediately below Prosser Dam (R3), at the Chandler facility outfall (R4), at the I-82 bridge (R5), or immediately below the main PIT-tag detector in the Chandler facility (R6) in 1992. Abbreviations: CHF-Chandler facility; MCN-McNary Dam; Det-Detected.

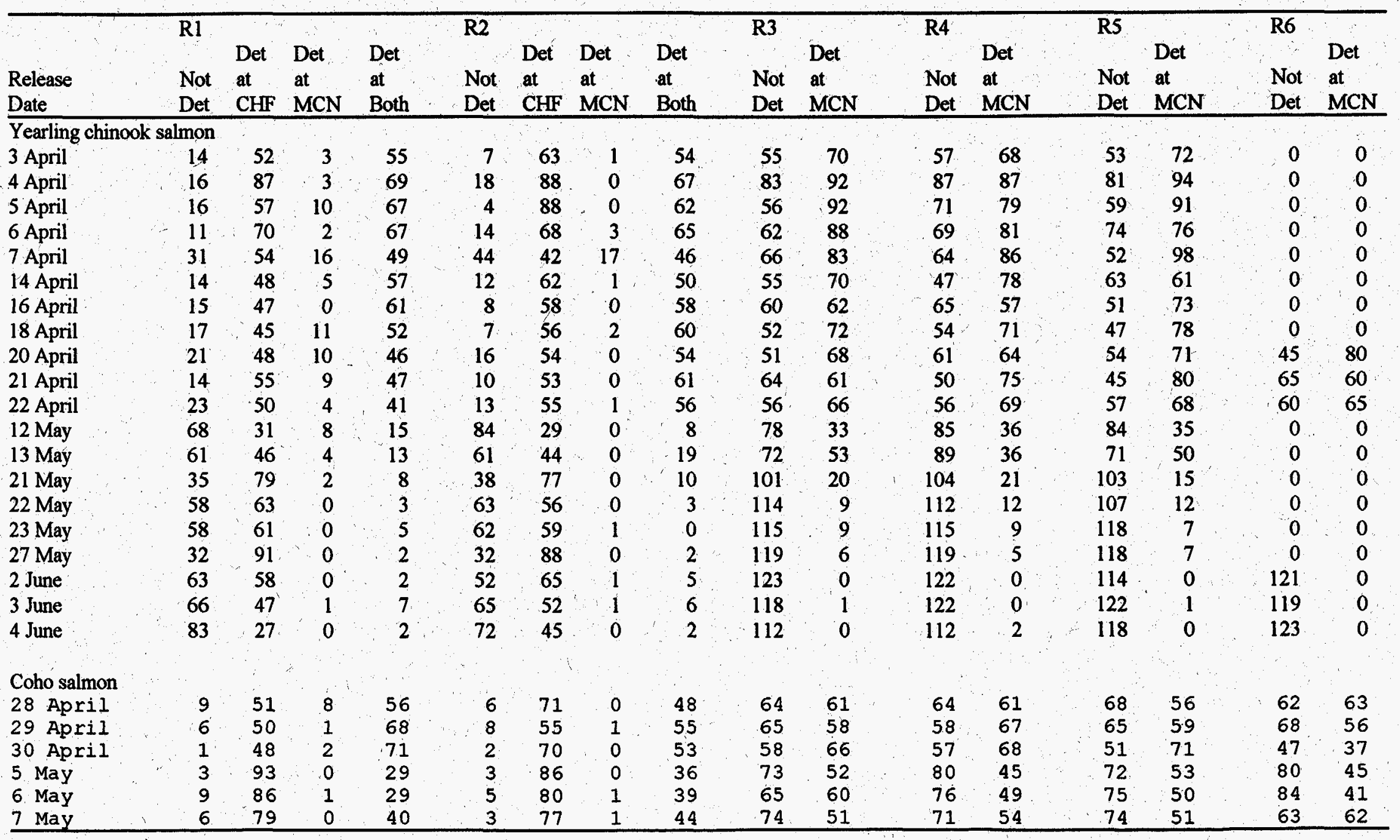


Appendix Table 6. Method-of-moment initial parameter estimates for iterative maximum likelihood analyses in 1991. Abbreviations: S1-Prosser Dam forebay survival; S2-Chandler Canal survival; S3-Prosser Dam to the Chandler facility outfall survival; SM1-Chandler facility outfall to McNary Dam survival and detection at McNary Dam; D-diversion proportion into the Chandler Canal; SA-Chandler facility to outfall survival; P-detection proportion at the Chandler facility.

\begin{tabular}{|c|c|c|c|c|c|c|c|}
\hline $\begin{array}{l}\text { Release } \\
\text { Date }\end{array}$ & $\mathbf{S 1}$ & $\mathbf{S 2}$ & S3 & SM1 & D & $\mathbf{S A}$ & $\mathbf{P}$ \\
\hline \multicolumn{8}{|c|}{ Yearling chinook salmon } \\
\hline 14 April & 1.021 & 0.987 & 0.957 & 0.467 & 0.626 & 0.860 & 1.000 \\
\hline 15 April & 1.155 & 0.983 & 0.957 & 0.470 & 0.410 & 0.942 & 0.977 \\
\hline 16 April & 1.095 & 0.990 & 1.012 & 0.405 & 0.641 & 0.998 & 1.000 \\
\hline 17 April & 0.967 & 0.964 & 1.282 & 0.425 & 0.779 & 0.842 & 0.986 \\
\hline 22 April & 0.930 & 0.945 & 1.247 & 0.365 & 0.648 & 1.102 & 1.000 \\
\hline 23 April & 0.918 & 0.925 & 0.978 & 0.445 & 0.473 & 0.940 & 1.000 \\
\hline 24 April & 0.964 & 0.986 & 1.090 & 0.443 & 0.537 & 1.019 & 0.989 \\
\hline 25 April & 0.866 & 0.964 & 0.915 & 0.524 & 0.585 & 0.844 & 1.000 \\
\hline 26 April & 0.977 & 0.977 & 0.991 & 0.520 & 0.746 & 0.993 & 0.991 \\
\hline $1 \mathrm{May}$ & 1.034 & 0.947 & 1.096 & 0.462 & 0.962 & 1.107 & 1.000 \\
\hline 2 May & 0.977 & 0.973 & 1.000 & 0.520 & 0.991 & 0.790 & 1.000 \\
\hline 3 May & 1.030 & 0.957 & 0.989 & 0.475 & 0.910 & 0.858 & 0.987 \\
\hline 4 May & 0.964 & 0.991 & 1.026 & 0.460 & 1.008 & 0.904 & 0.981 \\
\hline 5.May & 0.985 & 1.001 & 0.959 & 0.485 & 1.026 & 0.731 & 0.944 \\
\hline 7 May & 1.093 & 0.790 & 0.980 & 0.495 & 1.114 & 0.856 & 0.582 \\
\hline \multicolumn{8}{|c|}{ Coho salmon } \\
\hline $16 \mathrm{May}$ & 1.006 & 0.976 & 0.958 & 0.411 & 0.912 & 0.854 & 0.983 \\
\hline 17 May & 1.003 & 0.985 & 1.018 & 0.275 & 0.885 & 1.034 & 1.000 \\
\hline 18 May & 0.966 & 0.992 & 1.090 & 0.335 & 1.014 & 0.873 & 0.983 \\
\hline 21 May & 0.955 & 1.004 & 0.813 & 0.375 & 0.851 & 0.943 & 0.986 \\
\hline $22 \mathrm{May}$ & 0.953 & 0.989 & 1.382 & 0.170 & 0.913 & 1.011 & 0.971 \\
\hline
\end{tabular}


Appendix Table 7. Method-of-moment initial parameter estimates for iterative maximum likelihood analyses in 1992. Abbreviations: S1-Prosser Dam forebay survival; S2-Chandler Canal survival; S3-Prosser Dam to the Chandler facility outfall survival; S4-Chandler facility outfall to the I-82 bridge survival; SM2-I-82 bridge to McNary Dam survival and detection at McNary Dam; D-diversion proportion into the Chandler Canal; SAChandler facility to outfall survival; $P$-detection proportion at the Chandler facility.

\begin{tabular}{|c|c|c|c|c|c|c|c|c|}
\hline $\begin{array}{l}\text { Release } \\
\text { Date }\end{array}$ & S1 & $\mathbf{S} 2$ & S3 & S4 & SM2 & D & SA & $\mathbf{P}$ \\
\hline \multicolumn{9}{|c|}{ Yearling chinook salmon } \\
\hline 3 April & 0.940 & 0.953 & 1.029 & 0.944 & 0.576 & 0.973 & 0.848 & 0.982 \\
\hline 4 April & 1.038 & 0.896 & 1.057 & 0.926 & 0.537 & 0.969 & 0.865 & 1.000 \\
\hline 5 April & 0.910 & 0.974 & 1.165 & 0.868 & 0.607 & 0.909 & 0.785 & 1.000 \\
\hline 6 April & 1.018 & 0.928 & 1.086 & 1.066 & 0.507 & 1.012 & 0.905 & 0.956 \\
\hline 7 April & 1.130 & 0.813 & 0.965 & 0.878 & 0.653 & 1.024 & 0.901 & 0.730 \\
\hline 14 April & 0.983 & 0.914 & 0.897 & 1.279 & 0.492 & 0.954 & 0.715 & 0.980 \\
\hline 16 April & 0.931 & 0.935 & 1.088 & 0.781 & 0.589 & 1.000 & 1.070 & 1.000 \\
\hline 18 April & 0.960 & 0.959 & 1.014 & 0.910 & 0.624 & 0.871 & 0.911 & 0.968 \\
\hline 20 April & 1.021 & 0.871 & 1.063 & 0.901 & 0.568 & 0.853 & 0.977 & 1.000 \\
\hline 21 April & 1.057 & 0.927 & 0.813 & 0.938 & 0.640 & 0.839 & 0.884 & 1.000 \\
\hline 22 April & 0.875 & 0.904 & 0.957 & 1.015 & 0.544 & 0.937 & 0.914 & 0.982 \\
\hline 12 May & 1.399 & 0.306 & 0.944 & 1.029 & 0.294 & 0.889 & 0.727 & 1.000 \\
\hline 13 May & 1.040 & 0.508 & 1.472 & 0.720 & 0.413 & 0.901 & 1.047 & 1.000 \\
\hline 21 May & 1.125 & 0.696 & 0.952 & 1.400 & 0.127 & 0.889 & 0.684 & 1.000 \\
\hline 22 May & 1.119 & 0.484 & 0.750 & 1.000 & 0.101 & 1.000 & 0.525 & 1.000 \\
\hline 23 May & 1.100 & 0.492 & 1.000 & 1.286 & 0.056 & 1.000 & 0.230 & 1.000 \\
\hline 27 May & 1.033 & 0.738 & 1.200 & 0.714 & 0.056 & 1.000 & 0.551 & 1.000 \\
\hline \multicolumn{9}{|l|}{2 June $^{a}$} \\
\hline \multicolumn{9}{|l|}{3 June } \\
\hline \multicolumn{9}{|l|}{4 June ${ }^{a}$} \\
\hline \multicolumn{9}{|c|}{ Coho salmon } \\
\hline 28 April & 1.000 & 0.952 & 1.000 & 1.089 & 0.452 & 0.899 & 0.827 & 1.000 \\
\hline 29 April & 1,040 & 0.941 & 0.866 & 1.136 & 0.476 & 1.003 & 0.933 & 0.982 \\
\hline 30 April & 1.011 & 0.984 & 0,971 & 0.958 & 0.582 & 0.978 & 0.792 & 1.000 \\
\hline 5 May & 1.000 & 0.976 & 1.156 & 0.849 & 0.424 & 1.000 & 0.820 & 1.000 \\
\hline 6 May & 0.972 & 0.976 & 1.224 & 0.980 & 0.400 & 0.994 & 0.836 & 0.975 \\
\hline 7 May & 0.964 & 0.990 & 0.944 & 1.059 & 0.408 & 1.020 & 0.842 & 0.978 \\
\hline
\end{tabular}

a No estimates calculated due to very small sample sizes. 
Appendix Table 8. Sampling error precision of the daily parameter estimates (i.e., model-based standard errors) for maximum likelihood analyses in 1991. Abbreviations: S1-Prosser Dam forebay survival; S2-Chandler Canal survival; S3-Prosser Dam to the Chandler facility outfall survival; SM1-Chandler facility outfall to McNary Dam survival and detection at McNary Dam; D-diversion proportion into the Chandler Canal; SA-Chandler facility to outfall survival; P-detection proportion at the Chandler facility.

\begin{tabular}{|c|c|c|c|c|c|c|c|}
\hline $\begin{array}{l}\text { Release } \\
\text { Date } \\
\end{array}$ & S1 & S2 & S3 & SM1 & D & SA & $\mathbf{P}$ \\
\hline \multicolumn{8}{|c|}{ Yearling chinook salmon } \\
\hline 14 April & 0.062 & 0.009 & 0.121 & 0.041 & 0.057 & 0.097 & $--^{a}$ \\
\hline 15 April & 0.073 & 0.016 & 0.104 & 0.035 & 0.049 & 0.091 & 0.017 \\
\hline 16 April & 0.055 & 0.007 & 0.122 & 0.035 & 0.049 & 0.103 & -- \\
\hline 17 April & 0.040 & 0.017 & 0.134 & 0.035 & 0.041 & 0.093 & 0.014 \\
\hline 22 April & 0.060 & 0.016 & 0.151 & 0.034 & 0.049 & 0.137 & - \\
\hline \multicolumn{8}{|l|}{23 April $^{\mathrm{b}}$} \\
\hline 24 April & 0.063 & 0.011 & 0.118 & 0.035 & 0.048 & 0.106 & 0.011 \\
\hline 25 April & 0.060 & 0.012 & 0.086 & 0.033 & 0.046 & 0.079 & - \\
\hline 26 April & 0.040 & 0.012 & 0.090 & 0.033 & 0.041 & 0.080 & 0.009 \\
\hline 1 May & 0.023 & 0.015 & 0.107 & 0.033 & 0.017 & 0.092 & -- \\
\hline 2 May & 0.020 & 0.011 & 0.091 & 0.033 & 0.009 & 0.068 & -- \\
\hline 3 May & 0.031 & 0.017 & 0.105 & 0.035 & 0.031 & 0.082 & 0.013 \\
\hline 4 May & 0.018 & 0.012 & 0.098 & 0.032 & 0.015 & 0.077 & 0.014 \\
\hline 5 May & 0.024 & 0.021 & 0.101 & 0.035 & 0.028 & 0.078 & 0.025 \\
\hline \multicolumn{8}{|l|}{7 May $^{\mathrm{c}}$} \\
\hline Mean & 0.044 & 0.014 & 0.110 & 0.035 & 0.037 & 0.091 & 0.015 \\
\hline \multicolumn{8}{|c|}{ Coho salmon } \\
\hline 16 May & 0.035 & 0.018 & 0.124 & 0.037 & 0.037 & 0.096 & 0.018 \\
\hline 17 May & 0.043 & 0.009 & 0.164 & 0.032 & 0.043 & 0.150 & - \\
\hline 18 May & 0.018 & 0.010 & 0.149 & 0.033 & - & 0.115 & -- \\
\hline 21 May & 0.045 & 0.011 & 0.114 & 0.034 & 0,048 & 0.104 & 0.015 \\
\hline 23 May & 0.050 & 0.027 & 0.279 & 0.027 & 0.050 & 0.200 & 0.028 \\
\hline Mean & 0.038 & 0.015 & 0.166 & 0.033 & 0.045 & 0.133 & 0.020 \\
\hline
\end{tabular}

- Dashes indicate no standard error as parameter estimate was assumed to be 1.000 .

b No estimates calculated due to poor mixing at McNary Dam.

- No estimates calculated due to Chandler facility PIT-tag detector malfunction. 
Appendix Table 9. Sampling error precision of the daily parameter estimates (i.e., model-based standard errors) for maximum likelihood analyses in 1992. Abbreviations: S1-Prosser Dam forebay survival; S2-Chandler Canal survival; S3-Prosser Dam to the Chandler facility outfall survival; S4-Chandler facility outfall to the I-82 bridge survival; SM2-I-82 bridge to McNary Dam survival and detection at McNary Dam; D-diversion proportion into the Chandler Canal; SA-Chandler facility to outfall survival; P-detection proportion at the Chandler facility.

\begin{tabular}{|c|c|c|c|c|c|c|c|c|}
\hline $\begin{array}{l}\text { Release } \\
\text { Date } \\
\end{array}$ & S1 & $\mathbf{S} 2$ & S3 & S4 & SM2 & D & SA & $\mathbf{P}$ \\
\hline \multicolumn{9}{|c|}{ Yearling chinook salmon } \\
\hline 3 April & 0.038 & 0.022 & 0.117 & 0.106 & 0.044 & 0.029 & 0.096 & 0.017 \\
\hline 4 April & 0.037 & 0.023 & 0.110 & 0.096 & 0.038 & 0.018 & 0.087 & $--^{2}$ \\
\hline 5 April & 0.032 & 0.013 & 0.119 & 0.088 & 0.040 & 0.033 & 0.090 & - \\
\hline $\begin{array}{l}6 \text { April } \\
7 \text { April }^{b}\end{array}$ & 0.037 & 0.027 & 0.111 & 0.118 & 0.041 & 0.026 & 0.088 & 0.025 \\
\hline 14 April & 0.045 & 0.028 & 0.095 & 0.145 & 0.045 & 0.034 & 0.077 & 0.018 \\
\hline 16 April & 0,039 & 0.022 & 0.143 & 0.097 & 0.044 & - & 0.131 & $\cdots$ \\
\hline 18 April & 0.044 & 0.023 & 0.112 & 0.095 & 0.043 & 0.047 & 0.094 & 0.022 \\
\hline 20 April & 0.053 & 0.030 & 0.132 & 0.106 & 0.044 & 0.041 & 0.108 & -- \\
\hline 21 April & 0.048 & 0.024 & 0.095 & 0.093 & 0.043 & 0.044 & 0.075 & - \\
\hline 22 April & 0.051 & 0.029 & 0.114 & 0.117 & 0.045 & 0.036 & 0.088 & 0.018 \\
\hline \multicolumn{9}{|l|}{$12 \mathrm{May}^{\mathrm{b}}$} \\
\hline 13 May & 0.122 & 0.045 & 0.258 & 0.124 & 0.045 & 0.037 & 0.188 & -- \\
\hline 21 May & 0.103 & 0.041 & 0.281 & 0.413 & 0.031 & 0.060 & 0.184 & -- \\
\hline 22 May & 0.139 & 0.045 & 0.319 & 0.372 & 0.028 & -- & 0.240 & -- \\
\hline $23 \mathrm{May}$ & 0.135 & 0.045 & 0.454 & 0.632 & 0.021 & -- & 0.336 & -- \\
\hline 27 May & 0.076 & 0.040 & 0.705 & 0.412 & 0.021 & - & 0.358 & - \\
\hline April Mean & 0.042 & 0.024 & 0.115 & 0.106 & 0.043 & 0.034 & 0.093 & 0.020 \\
\hline May Mean & 0.115 & 0.043 & 0.403 & 0.391 & 0.029 & 0.049 & 0.261 & - \\
\hline \multicolumn{9}{|l|}{ Coho salmon } \\
\hline 28 April & 0.041 & 0.019 & 0.130 & 0.146 & 0.045 & 0.042 & 0.105 & - \\
\hline 29 April & 0.035 & 0.025 & 0.111 & 0.142 & 0.045 & 0.025 & 0.093 & 0.017 \\
\hline 30 April & 0.017 & 0.011 & 0.115 & 0.105 & 0.045 & 0.021 & 0.090 & - \\
\hline 5 May & 0.020 & 0.014 & 0.184 & 0.134 & 0.044 & - & 0.119 & -- \\
\hline $6 \mathrm{May}$ & 0.032 & 0.026 & 0.178 & 0.153 & 0.044 & 0.024 & 0.106 & 0.026 \\
\hline 7 May & 0.024 & 0.014 & 0.140 & 0.157 & 0.044 & - & 0.112 & -- \\
\hline Mean & 0.028 & 0.018 & 0.143 & 0.140 & 0.045 & 0.028 & 0.104 & 0.022 \\
\hline
\end{tabular}

Dashes indicate no standard error as parameter estimate was assumed to be 1.000 .

b No estimates calculated due to Chandler facility PIT-tag detector malfunction. 
Appendix Table 10. Yakima River water temperature and flow on test dates when survival parameters were estimated in 1991 and 1992.

\begin{tabular}{|c|c|c|c|c|}
\hline $\begin{array}{l}\text { Release } \\
\text { date }\end{array}$ & $\begin{array}{l}\text { Yakima } \\
\text { River } \\
\text { water } \\
\text { temperature } \\
\left({ }^{\circ} \mathrm{C}\right)\end{array}$ & $\begin{array}{l}\text { Prosser } \\
\text { Dam Forebay } \\
\text { water } \\
\text { flow } \\
\text { (cms) }\end{array}$ & $\begin{array}{l}\text { Prosser } \\
\text { Dam Tailrace } \\
\text { water } \\
\text { flow } \\
\text { (cms) }\end{array}$ & $\begin{array}{l}\text { Chandler } \\
\text { Canal } \\
\text { water } \\
\text { flow } \\
\text { (cms) }\end{array}$ \\
\hline 14 April 1991 & 10.0 & 115.9 & 75.9 & 40.0 \\
\hline 15 April 1991 & 10.0 & 129.7 & 89.9 & 39.8 \\
\hline 16 April 1991 & 10.0 & 128.7 & 88.9 & 39.8 \\
\hline 17 April 1991 & 9.4 & 128.1 & 88.0 & 40.0 \\
\hline 22 April 1991 & 12.8 & 124.6 & 85.1 & 39.5 . \\
\hline 23 April 1991 & 12.8 & 136.4 & 96.7 & 39.7 \\
\hline 24 April 1991 & 12.2 & 145.1 & 105.7 & 39.4 \\
\hline 25 April 1991 & 11.1 & 133.0 & 93.9 & 39.1 \\
\hline 26 April 1991 & 10.6 & 115.9 & 76.2 & 39.6 \\
\hline 1 May 1991 & 12.8 & 75.7 & 35.2 & 40.5 \\
\hline 2 May 1991 & 13.3 & 71.9 & 31.8 & 40.2 \\
\hline 3 May 1991 & 13.3 & 70.7 & 30.5 & 40.2 \\
\hline 4 May 1991 & 14.4 & 70.4 & 30.3 & 40.1 \\
\hline 5 May 1991 & 14.4 & 71.3 & 31.0 & 40.2 \\
\hline 16 May 1991 & 14.4 & 90.1 & 49.5 & 40.6 \\
\hline 17 May 1991 & 13.9 & 85.5 & 45.0 & 40.5 \\
\hline 18 May 1991 & 13.9 & 87.9 & 47.3 & 40.6 \\
\hline 21 May 1991 & 15.0 & 104.4 & 63.2 & 41.2 \\
\hline 23 May 1991 & 16.1 & 105.9 & 64.5 & 41.4 \\
\hline 3 April 1992 & 14.4 & 49.1 & 12.4 & 36.8 \\
\hline 4 April 1992 & 13.3 & 52.7 & 15.5 & 37.2 \\
\hline 5 April 1992 & 12.2 & 58.6 & 20.7 & 37.9 \\
\hline 6 April 1992 & 11.1 & 57.6 & 20.2 & 37.4 \\
\hline 14 April 1992 & 12.8 & 58.3 & 28.1 & 30.2 \\
\hline 16 April 1992 & 15.0 & 54.4 & 19.2 & 35.2 \\
\hline 18 April 1992 & 13.3 & 80.9 & 42.9 & 38.0 \\
\hline 20 April 1992 & 12.8 & 97.3 & 59.6 & 37.7 \\
\hline 21 April 1992 & 12.2 & 84.8 & 47.1 & 37.7 \\
\hline 22 April 1992 & 11.7 & 70.3 & 33.0 & 37.3 \\
\hline 28 April 1992 & 16.7 & 48.9 & 13.8 & 35.2 \\
\hline 29 April 1992 & 17.2 & 52.4 & 16.9 & 35.5 \\
\hline 30 April 1992 & 16.1 & 63.8 & 27.1 & 36.7 \\
\hline 5 May 1992 & 17.8 & 56.1 & 19.8 & 36.3 \\
\hline 6 May 1992 & 18.3 & 51.1 & 15.9 & 35.2 \\
\hline 7 May 1992 & 20.0 & 49.2 & 14.9 & 34.4 \\
\hline 13 May 1992 & 16.1 & 42.5 & 20.3 & 22.2 \\
\hline 21 May 1992 & 17.8 & 44.8 & 18.3 & 26.5 \\
\hline 22 May 1992 & 17.2 & 41.3 & 16.8 & 24.5 \\
\hline 23 May 1992 & 18.9 & 39.4 & 17.0 & 22.5 \\
\hline 27. May 1992 & 20.6 & 44.9 & 19.3 & 25.6 \\
\hline 2 June 1992 & 22.2 & 31.3 & 7.6 & 23.6 \\
\hline 3 June 1992 & 21.1 & 31.7 & 7.9 & 23.8 . \\
\hline 4 June 1992 & 22.2 & 34.2 & 10.1 & 24.1 \\
\hline
\end{tabular}

